UNIVERSIDADE DE BRASÍLIA

FACULDADE DE DIREITO

\title{
POSSIBILIDADES DA JUSTIÇA RESTAURATIVA NO SISTEMA PENAL BRASILEIRO
}

\author{
AMANDA ALMEIDA WAQUIM
}

BRASÍLIA, JULHO DE 2011. 


\section{AMANDA ALMEIDA WAQUIM}

\section{POSSIBILIDADES DA JUSTIÇA RESTAURATIVA NO SISTEMA PENAL BRASILEIRO}

Monografia apresentada à Universidade de Brasília para obtenção do título de Bacharel em Direito.

Orientadora: Professora Carolina Costa Ferreira

BRASÍLIA, JULHO DE 2011. 
Monografia de graduação apresentada à Faculdade de Direito da Universidade de Brasília por Amanda Almeida Waquim, intitulada Possibilidades da Justiça Restaurativa no Sistema Penal Brasileiro e considerada aprovada pela banca examinadora.

Orientadora: Professora Carolina Costa Ferreira

Membro: Professora Dra. Ela Wiecko Volkmer de Castilho

Membro: Professora Dra. Beatriz Vargas

Brasília, julho de 2011. 
Aos meus pais, sempre. 


\section{AGRADECIMENTOS}

Primeiramente, meus agradecimentos se voltam para a minha querida família e para o meu noivo. Sem dúvidas, a compreensão, o amor e o incentivo de todos foram o meu alimento para me manter nessas distantes terras candangas. A estas também, todas as minhas honras.

À Universidade de Brasília, por ter me proporcionado grandes mestres, amigos inesquecíveis e momentos de verdadeiro crescimento pessoal, acadêmico e profissional.

Nos corredores da Faculdade de Direito, pude encontrar algumas respostas para várias de minhas inquietações. Entre estas, as questões acerca do direito penal, cárcere e da criminalidade no nosso país. Tal curiosidade me levou às aulas de Criminologia, disciplina facultativa desta faculdade ministrada pela Prof ${ }^{a}$. Carolina Costa Ferreira. Professora que me revelou razões até então desconhecidas e que me possibilitou um primeiro contato com o tema da Justiça Restaurativa, por isso, não poderia deixar de agradecê-la. Muito obrigada. Ainda, obrigada novamente por ter aceitado o convite de ser minha orientadora.

Também, minhas menções às professoras Ela Wiecko e Beatriz Vargas, por, em algumas disciplinas lecionadas, terem ampliado meu horizonte acerca da justiça penal. Aqui, aproveito para agradecer ao Projeto de Extensão Além das Grades, bem como aos colegas que pude conhecer através dele, por ter enriquecido a minha noção de cidadania e ter me dado a convicção de que as mudanças precisam acontecer.

A realização da pesquisa apresentada neste trabalho não teria sido possível sem a contribuição dos membros do Programa de Justiça Restaurativa do Núcleo Bandeirante, que realizam, na prática, grandes mudanças. Meu obrigada especial é para os mediadores Manoel Pereira e Helena Costa e à juíza Léa Martins, por terem, de verdade, me recebido de braços abertos. Aproveito para parabenizá-los pelos profissionais humanos que são. Deixo aqui, como aprendido no Núcleo, um grande abraço restaurativo. 
Enfim, como toda menção é injusta porque omissões são inevitáveis, quero lembrar que várias pessoas foram importantes ao longo da minha jornada acadêmica e para a produção deste trabalho.

A todos aqui mencionados, e aos que não pude citar, meus agradecimentos são e serão, sempre, ternos e eternos. 
“Onde houver justiça, não haverá vingança. Não basta combatermos os crimes, quando nada fazemos para evitá-los."

(Nicolau Waquim Neto)

"E os homens imunizados contra o crime, cidadãos de um novo mundo, contarão às crianças do futuro histórias absurdas de prisões, celas, altos muros de um tempo superado."

(Cora Coralina)

“As novas ideias são primeiro ignoradas, depois são violentamente combatidas, depois são adotadas como evidentes justamente pelos que as combateram."

(Schopenhauer) 


\section{RESUMO}

A justiça restaurativa destaca-se no cenário internacional contemporâneo como uma forma de resolução de conflitos diversa do modelo de justiça criminal tradicional. Surge a partir dos movimentos de contestação das instituições repressivas e da participação dada às vítimas no processo penal e, assim, passa a ser construída sob princípios diversos. No Brasil, diante da realidade seletiva, repressiva e desproporcional apresentada pelo nosso sistema penal, a justiça restaurativa ganha força como outra opção no controle de crime. A partir da implantação, em 2005, de projetos-piloto restaurativos no cenário pátrio, o tema recebeu maior atenção nos meios acadêmicos e institucionais brasileiros. Contudo, as experiências restaurativas nacionais, principalmente quanto à justiça penal para adultos, limitam-se aos casos dos crimes tidos como de menor potencial ofensivo. Assim, diante da abordagem teórica e prática do modelo restaurativo e da limitação das experiências brasileiras, a investigação empírica realizada neste trabalho, a partir da análise do projeto-piloto realizado no Núcleo Bandeirante (DF), permitiu verificar que a ampliação da justiça restaurativa no Brasil para os crimes de maior potencial ofensivo é juridicamente possível e socialmente necessária.

Palavras-chave: justiça restaurativa - ampliação - sistema penal brasileiro - projeto do Núcleo Bandeirante (DF) - crimes de maior potencial ofensivo. 


\section{SUMÁRIO}

INTRODUÇÃO

CAPÍTULO I: BASES TEÓRICAS QUE ANTECEDERAM O SURGIMENTO DA JUSTIÇA RESTAURATIVA: CRIMINOLOGIA, POLÍTICA CRIMINAL E

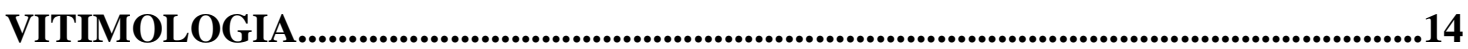

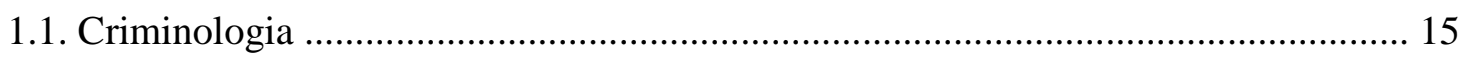

1.1.1. O paradigma etiológico........................................................................... 15

1.1.2. Criminologia crítica e o paradigma da reação social....................................19

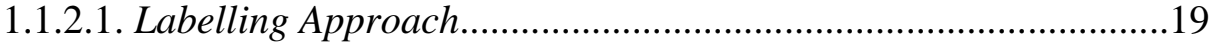

1.1.2.2. Criminologia Crítica.........................................................................2

1.2. Políticas Criminais e Justiça Restaurativa: o pensamento abolicionista........................30

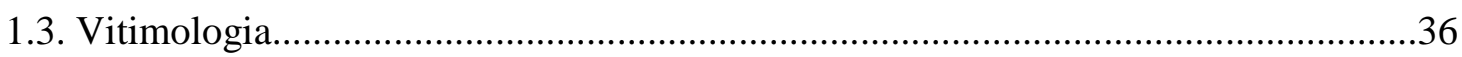

CAPÍTULO II: O SISTEMA PENAL BRASILEIRO................................................41

2.1. A crise dos sistemas penais....................................................................................4

2.2. O sistema penal brasileiro....................................................................................

2.3. A realidade prisional brasileira...............................................................................46

CAPÍTULO III: A TEORIA RESTAURATIVA............................................................54

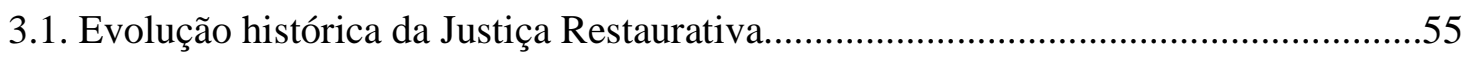

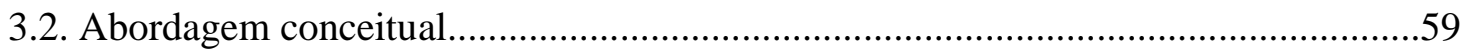

3.3. Valores restaurativos e contornos práticos..................................................................61

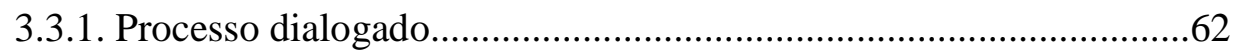

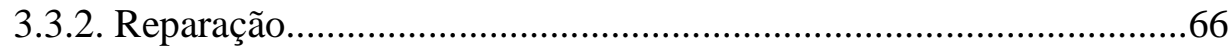


CAPÍTULO IV: O PROGRAMA DE JUSTIÇA RESTAURATIVA REALIZADO NO NÚCLEO BANDEIRANTE-DF..................................................................................71

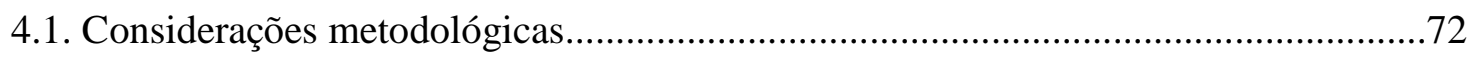

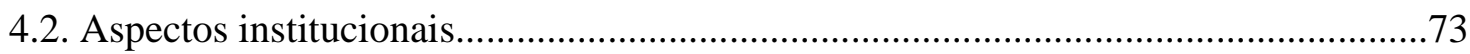

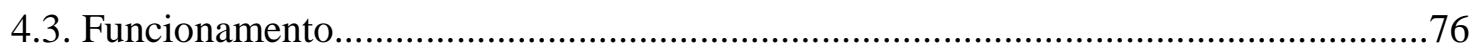

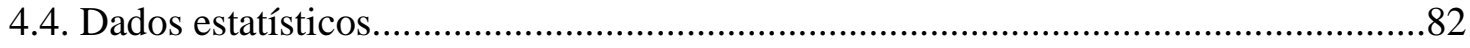

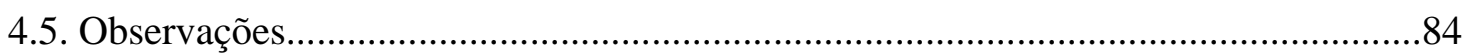

4.6. Estudo de caso: artigo 213 do Código Penal............................................................. 88

CAPÍtUlO V: NOVAS POSSIBILIDADES: A DERIVAÇÃO À JUSTIÇA RESTAURATIVA DOS TIPOS PENAIS MAIS GRAVES NO SISTEMA PENAL BRASILEIRO.................................................................................................................................96

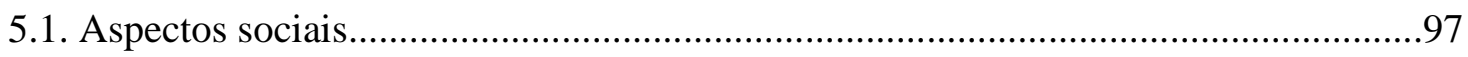

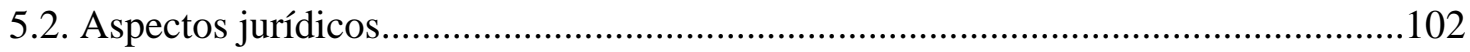

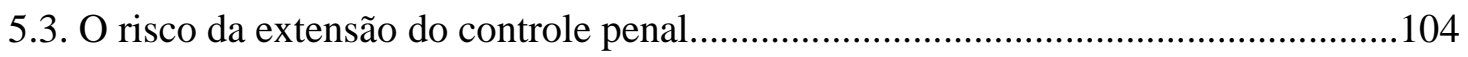

CONCLUSÃO........................................................................................................... 108

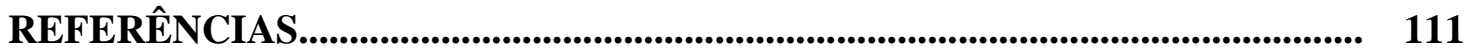

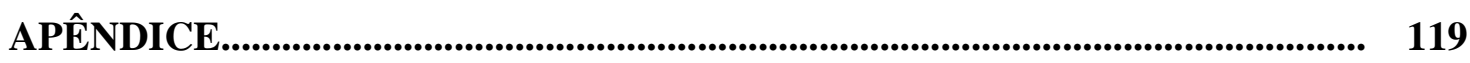

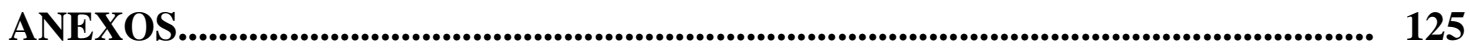




\section{INTRODUÇÃO}

A crise de legitimidade do discurso jurídico-penal, bem como a crescente violência urbana, tem preocupado vários setores, instituições e ciências da sociedade. Nesse contexto, a Justiça Restaurativa surge como importante tema nos debates acerca do futuro da justiça criminal. Isso porque o modelo restaurativo representa o que se deve esperar da intervenção estatal em relação ao fenômeno criminal: uma tentativa de conciliar as justas expectativas da vítima, do infrator e da sociedade. No Brasil, as discussões acerca do assunto ganharam relevância a partir da criação de projetos-pilotos para a implantação dessa nova forma de administração dos conflitos penais no país. Assim, uma vez introduzido o tema no cenário nacional, cumpre observar em que moldes este modelo está sendo realizado.

A hipótese da qual partimos é a de que, a exemplo de outros países, a Justiça Restaurativa deve ser ampliada para os tipos penais tidos como de maior potencial ofensivo. Apenas com esta medida pode-se pensar no alcance de seu potencial transformador. Para a verificação empírica de tal hipótese, realizou-se uma pesquisa acerca do Programa de Justiça Restaurativa dos Juizados Especiais Criminais do Núcleo Bandeirante, Distrito Federal, e foi examinado, com mais profundidade, um caso específico de estupro presumido encaminhado ao programa restaurativo. A partir desse estudo de caso, percebeu-se que é possível, no ordenamento jurídico brasileiro, que a Justiça Restaurativa, em várias das suas possibilidades práticas, seja aplicada a crimes mais graves.

A partir dessas considerações é que o presente trabalho se propõe a desenvolver os aspectos teóricos e práticos da Justiça Restaurativa, bem como caracterizá-la no contexto brasileiro.

Para tanto, este trabalho será estruturado em cinco capítulos. 
No primeiro capítulo, serão estudados os principais antecedentes teóricos da Justiça Restaurativa. Assim, abordar-se-á as contribuições da Criminologia, principalmente as formulações desenvolvidas pela teoria do Labelling Approach, Criminologia Crítica e Abolicionismo, além da Vitimologia. Ressalta-se que será brevemente analisado o paradigma etiológico na Criminologia, a fim de possibilitar uma compreensão das origens da ideologia da defesa social em que se funda o sistema de justiça penal brasileiro. Durante o capítulo, serão demonstradas as proximidades e distanciamentos conceituais entre os antecedentes e a teoria restaurativa. Neste ponto, é importante pontuar que o referencial teórico adotado neste trabalho é pelo paradigma da reação social e, em termos de política criminal, pelo Minimalismo Penal.

Por conseguinte, no segundo capítulo, o objetivo consiste em caracterizar o contexto brasileiro em que emerge a importância da adoção de práticas restaurativas, qual seja: a crise de legitimação dos sistemas penais. Assim, será caracterizado o sistema penal brasileiro partindo-se dos aspectos da seletividade, desigualdade, repressão e estigmatização, todos desenvolvidos pela Criminologia da reação social. Características estas que produzem uma realidade penitenciária muito grave, com multiplicidade de delitos e violações flagrantes e contínuas dos direitos humanos. A caracterização do sistema prisional brasileiro, portanto, é importante para que se demonstre a necessidade e urgência da Justiça Restaurativa como meio para tentar evitar o encarceramento em massa.

No terceiro capítulo, serão desenvolvidos os aspectos teóricos e práticos da Justiça Restaurativa e sua evolução histórica. Inicialmente, será demonstrado que as práticas consensuais de resolução de conflitos já permeavam as sociedades antigas e préestatais, ou seja, anteriores à concepção do Estado Moderno. Por conseguinte, estudar-seá a questão da abertura conceitual do termo, abordando-se a importância de que mantenha a flexibilidade de suas definições para que não impeça o encaixe de novos projetos restaurativos e nem torne sua prática burocratizada. Assim, diante de tal abertura, é que serão caracterizados os principais valores do modelo restaurativo, eis que a vinculação a 
estes princípios é que determina se um processo pode ser considerado verdadeiramente restaurativo ou não. Optou-se por apresentar somente os valores restaurativos tidos como essenciais ao modelo restaurativo, sem apego às classificações propostas por alguns teóricos.

Após a construção da base teórica, a fim de confrontar a teoria e práxis, analisarse-á a experiência do programa realizado no Núcleo Bandeirante, Distrito Federal, iniciada no ano de 2005. Projeto este que se encontra vinculado ao âmbito de competência dos Juizados Especiais Criminais previstos na Lei $n^{\circ}$ 9.099/95, o que, consequentemente, o limita aos casos de menor potencial ofensivo. Para investigação do programa, foi realizada pesquisa empírica, utilizando-se da seguinte metodologia: visitas locais, entrevistas com membros do projeto, análise documental e participação em encontro. Ressalta-se que a pesquisa possuiu a pretensão modesta de conhecer o funcionamento do projeto e, por ter sido baseada principalmente em dados secundários, não intenta realizar uma profunda avaliação qualitativa do programa. No entanto, serão formuladas algumas observações consideradas pertinentes. Ainda, para sustentar a possibilidade de ampliação da Justiça Restaurativa no sistema penal brasileiro quanto aos crimes mais graves, será utilizado como caso paradigmático o fato enquadrado no tipo penal de estupro presumido que foi encaminhado ao programa do Núcleo Bandeirante.

Por fim, além de o caso apresentado avalizar a tese aqui defendida, serão apresentados os argumentos de natureza jurídica e social capazes de demonstrar, diante das nossas peculiaridades, que a ampliação da justiça restaurativa para os crimes ditos de maior potencial ofensivo é juridicamente possível e socialmente necessária. Entre os argumentos, também será abordado o risco da extensão do controle penal.

Enfim, o trabalho defende que é preciso superar os entraves que as medidas legais e o atual modelo de organização da justiça criminal brasileira constituem para um melhor desenvolvimento da Justiça Restaurativa no Brasil. 


\subsection{BASES TEÓRICAS QUE ANTECEDERAM O SURGIMENTO DA JUSTIÇA RESTAURATIVA: CRIMINOLOGIA, POLÍticA CRIMINAL E VITIMOLOGIA}

Nos diversos estudos acerca da justiça restaurativa, podem-se encontrar algumas correntes teóricas apontadas como influentes para o seu surgimento nas sociedades modernas ${ }^{1}$. No entanto, no presente trabalho, adotou-se a direção dada por Elena Larrauri (2009, p.169):

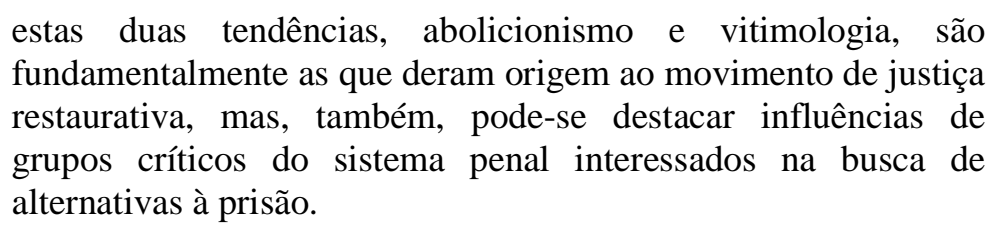

Aqui, dentre tais grupos, encontra-se a importância dos estudiosos do labelling approach e da Criminologia Crítica.

Assim, o arcabouço teórico que pode ser identificado como propício ao nascimento das ideias acerca da justiça restaurativa perpassa, historicamente, pelas seguintes construções conceituais: teoria do Labelling Approach, a Criminologia Crítica, Abolicionismo e Vitimologia, todas cronologicamente localizadas, principalmente, na segunda metade do século XX. São nestas que se encontram as noções mais relevantes que passaram a justificar a adoção das práticas restaurativas, no século XX, por países europeus e anglo-saxões (Estados Unidos, Canadá, Austrália, Nova Zelândia, etc.). Portanto, como se verá adiante, a justiça restaurativa é fruto de uma complexa conjuntura teórica.

\footnotetext{
${ }^{1}$ Mylène Jaccoud sustenta que, nas sociedades contemporâneas ocidentais, além das correntes a serem abordadas aqui, tem-se o movimento da exaltação da comunidade, que promoveu as virtudes da comunidade. O princípio da comunidade valoriza a melhor administração dos conflitos através da regra de negociação (JACCOUD, 2005, p.164). Ressalta-se que esse movimento não será abordado nesta oportunidade.
} 


\subsection{CRIMINOLOGIA}

\subsubsection{O PARADIGMA ETIOLÓGICO}

Inicialmente, antes de adentrar na explanação dos postulados trazidos pela Criminologia Crítica, torna-se imprescindível abordar, ainda que resumidamente, os estudos criminológicos que antecederam àquela: a Criminologia Positivista.

Quando se fala da Criminologia Positivista como a primeira fase de desenvolvimento da Criminologia, entendida como disciplina autônoma, se faz referência às teorias desenvolvidas na Europa entre o final do século XIX e o começo do século XX, no âmbito da Filosofia e do Positivismo naturalista, aludindo-se, especialmente, à Escola Positivista da Itália, com os estudos de Cesare Lombroso, Enrico Ferri e Raffaele Garofalo (BARATTA, 2002, p. 32).

A Criminologia Positivista desenvolveu-se na tentativa de conferir à disciplina o estatuto de uma ciência segundo os pressupostos epistemológicos do Positivismo - por isso mesmo positivista - e ao fenômeno, mais amplo, de cientificização do controle social, constituindo suas matizes na conformação do paradigma etiológico da criminalidade (ANDRADE, 1996, p. 276).

Foi, a partir dessa pretensão científica e baseado no determinismo orgânico e psíquico do crime, que o médico alienista italiano, Cesare Lombroso partiu para o Sul da Itália em busca da identificação das causas biológicas e psicológicas que diferenciariam os sujeitos delinquentes dos indivíduos normais. A metodologia empírica utilizada por Lombroso foi a análise dos "criminosos" que já se encontravam nas prisões e nos manicômios. Após verificar constantes comuns nos presos, concluiu que:

A maioria dos delinquentes natos tinha orelhas de abano, cabelos abundantes, barba escassa, seios frontais separados, mandíbula enorme, queixo quadrado ou saliente, pomos largos, gesticulação 
frequente, um tipo, em resumo, semelhante ao mongol e algumas vezes ao negróide. (ANITUA, 2008, p.299)

Segundo Baratta (2002, p.39), “essa orientação de pensamento buscava, de fato, a explicação da criminalidade na 'diversidade' ou anomalia dos autores de comportamentos criminalizados". Assim, o delinquente e sua personalidade perigosa foram definidos como os verdadeiros objetos de análise da Criminologia Positivista. Ressalte-se que a denominação de "homem delinquente" seria a de um ente diferenciado, como se constituísse outra raça diferente, em todos os aspectos, da dos seres humanos normais (ANITUA, 2008, p. 297).

$\mathrm{Na}$ base do paradigma etiológico, considerava-se a criminalidade como uma realidade ontológica, ou seja, anterior ao Direito Penal, por isso seria possível a explicação das causas que levariam um indivíduo a delinquir, bem como a determinação do "tratamento" que seria cabível para a recuperação daquele, pois o criminoso deveria ser ressocializado e neutralizado. "Este saber causal gerou, pois, um saber tecnológico: não apenas o diagnóstico da patologia criminal, mas acompanhada do remédio que cura" (ANDRADE, 1996, p. 278). Assim, surge o direito penal do autor e a doutrina do tratamento e inocuização de infratores. Nesse contexto, o cárcere ganha posição de destaque e se consolida como o meio capaz de realizar efetivamente essa função ressocializadora do delinquente.

Dessa forma, a Criminologia Positivista nasce com a pretensão de se desenvolver como uma ciência causal-explicativa, "ela indaga, fundamentalmente, o que o homem (criminoso) faz e porque o faz" (ANDRADE, 1996, p.277). Nesse sentido, "a nova disciplina científica conseguiu, desse modo, concentrar-se no estudo clínico do homem delinquente, que já nascera assim e cujos comportamentos deveriam ser evitados" (ANITUA, 2008, p. 305).

Partindo dos pressupostos e indagações acima tratados, surge, com a Criminologia Positivista, a ideia da luta contra a criminalidade, em defesa da sociedade, esta passando 
a experimentar uma única e maniqueísta assimetria: a divisão entre o bem e o mal (ANDRADE, 1996, p.278). Aqui, partindo daquela divisão, a Escola Positivista consolida a ideologia da defesa social ${ }^{2}$, esta sintetizada primorosamente por Baratta (2002, p. 42-43). a partir dos seguintes princípios:

a) Princípio de legitimidade. O Estado, como expressão da sociedade, está legitimado para reprimir a criminalidade, da qual são responsáveis determinados indivíduos, por meio de instâncias oficiais de controle social (legislação, polícia, magistratura, instituições penitenciárias). Estas interpretam a legítima reação da sociedade, ou da grande maioria dela, dirigida à reprovação e condenação do comportamento desviante individual e à reafirmação dos valores e das normas sociais.

b) Princípio do bem e do mal. O delito é um dano para a sociedade. $\mathrm{O}$ delinquente é um elemento negativo e disfuncional do sistema social. O desvio criminal é, pois, o mal; a sociedade constituída, o bem.

c) Princípio da culpabilidade. O delito é expressão de uma atitude interior reprovável, porque contrária aos valores e às normas, presentes na sociedade mesmo antes de serem sancionadas pelo legislador.

d) Princípio da finalidade ou da prevenção. A pena não tem, ou não tem somente, a função de retribuir, mas a de prevenir o crime. Como sanção abstratamente prevista pela lei, tem a função de criar uma justa e adequada contramotivação ao comportamento criminoso. Como sanção concreta, exerce a função de ressocializar o delinquente.

e) Princípio da igualdade. A criminalidade é violação da lei penal e, como tal, é o comportamento de uma minoria desviante. A lei penal é igual para todos. A reação penal se aplica de modo igual aos autores de delitos.

f) Princípio do interesse social e do delito natural. O núcleo central dos delitos definidos nos códigos penais das nações civilizadas representa ofensa de interesses fundamentais, de condições essenciais à existência de toda sociedade. Os interesses protegidos pelo direito penal são interesses comuns a todos os cidadãos. Apenas uma pequena parte dos delitos representa violação de determinados arranjos políticos e econômicos, e é punida em função da consolidação destes (delitos artificiais).

\footnotetext{
${ }^{2}$ Baratta adverte que, desde a Escola Clássica - anterior à Escola Positivista e que não foi tratada neste estudo - pode-se encontrar, salvo algumas exceções, a presença da afirmação de uma ideologia da defesa social. A Escola Positiva, apesar de se assentar em pressupostos distintos, herdou-a da Escola Clássica (BARATTA, 2002, p.41).
} 
Infortunadamente - mas não inconscientemente -, essa ideologia da defesa social permanece atual tanto no que tange à filosofia dominante na ciência jurídico-penal quanto às opiniões comuns, não só dos representantes do aparato penal penitenciário, mas também do homem da rua (BARATTA, 2002, p. 42). Completando esse raciocínio, Vera Andrade (1996, p.278) sintetiza, no trecho abaixo, as expressões chaves da Criminologia Positivista que reforçaram e consolidaram a falaciosa ideologia da defesa social:

As representações do determinismo/criminalidade ontológica/ periculosidade/anormalidade/tratamento/ressocialização se complementam num círculo extraordinariamente fechado conformando uma percepção da criminalidade que se encontra, há um século, profundamente enraizada nas agências do sistema penal e do senso comum.

Por fim, tendo a Criminologia Positivista desenvolvido seus principais postulados a partir do estudo do seu objeto - o criminoso-, sem, contudo, ter conseguido desvencilhálo da lei penal e do sistema penal, sua contribuição, antes de tudo, foi legitimar a ciência penal como ciência do controle social. Nesse contexto, válida a observação de Massimo Pavarini:

Foi precisamente pela aprovação determinante do positivismo criminológico que o sistema repressivo se legitimou como defesa social. O conceito de defesa social tem subjacente uma ideologia cuja função é justificar e racionalizar o sistema de controle social em geral e repressivo em particular. (...) A defesa social é portanto uma ideologia extremamente sedutora, enquanto é capaz de enriquecer o sistema repressivo (vigente) com os atributos da necessidade, da legitimidade e da cientificidade. (PAVARINI apud ANDRADE, 1996, p. 286).

No entanto, apesar de toda a cientificidade e ideologia defendida pela Criminologia Positivista, houve, pelo menos quanto ao aspecto epistemológico, uma revolução paradigmática no âmbito das ciências criminais. Daí, em oposição à Criminologia então tradicional, surge a Criminologia da Reação Social. 


\subsubsection{CRIMINOLOGIA CRÍTICA E O PARADIGMA DA REAÇÃO SOCIAL}

\subsubsection{LABELLING APPROACH}

As teorias criminológicas liberais que compunham a Criminologia Crítica, em relação às teorias etiológicas da criminalidade que compõe a Criminologia Positivista, representam um decisivo progresso no âmbito do pensamento criminológico burguês, pois substituíram a dimensão biopsicológica do fenômeno criminal pela dimensão sociológica (BARATTA, 2002, p.147). Dentre essas teorias liberais, têm-se as teorias funcionalista, das subculturas, psicanalítica da sociedade punitiva e a do labelling approach.

A teoria estrutural-funcionalista citada acima, desenvolvida por Émile Durkheim, em 1985, e aperfeiçoada por Robert Merton, em 1983, contribuiu fortemente para a negação da dicotomia social do bem e do mal, ao construir a ideia da criminalidade como fenômeno normal, útil e, até, necessário. Assim, concebe-se que "o delito aparece estreitamente ligado às condições de toda vida coletiva" e, dentro de seus limites normais e funcionais, provocando e estimulando a reação social, estabiliza e mantém vivo o sentimento coletivo que sustenta o corpo social (DURKHEIM apud BARATTA, 2002, p. 60). Durkheim afirma que "o crime é necessário; está ligado às condições fundamentais de qualquer vida social, mas precisamente por isso, é útil; porque estas condições de que é solidário são elas mesmas indispensáveis à evolução normal da moral e do direito (DURKHEIM apud GROSNER, 2008, p.34). Ainda, para maior compreensão:

Assim vistos, os fatos fundamentais da criminologia surgem-nos sob um aspecto inteiramente novo. Contrariamente às idéias correntes, o criminoso já não aparece como um ser radicalmente insociável, como uma espécie de elemento parasitário, de corpo estranho e inassimilável, introduzido no seio da sociedade; é um agente regular da vida social. (DURKHEIM apud GROSNER, 2008, p.34). 
A teoria das subculturas, por outro lado, ao introduzir o conceito de subculturas, desconstruiu o princípio da culpabilidade defendido pela ideologia da defesa social. Em suma, segundos os autores desta teoria, o que origina a formação das subculturas criminais, na sociedade industrializada, é a desigual distribuição dos meios legítimos para que os indivíduos alcancem os fins culturais. Por conseguinte, no âmbito dos estratos sociais mais baixos, desenvolvem-se normas e modelos de comportamentos desviantes daqueles característicos dos estratos médios. Portanto, a constituição de subculturas criminais representa a reação de minorias desfavorecidas e a tentativa, por parte delas, de se orientarem dentro da sociedade, não obstante as reduzidas possibilidades legítimas de agir, de que dispõem (BARATTA, 2002, p.70). Assim, "por tal teoria, o crime resulta da interiorização e da obediência a um código moral ou cultural que torna a delinquência imperativa e, assim, ao obedecer às normas subculturais, o delinquente mais não pretende do que corresponder à expectativa dos outros significantes que definem o seu meio cultural e funcionam como grupo de referência para efeitos de status e de sucesso" (DIAS e ANDRADE apud GROSNER, 2008, p.35).

Todas essas teorias sociológicas criaram bases para a formação de uma concepção crítica quanto à ideia da criminalidade como realidade ontológica, esta própria do paradigma etiológico. No entanto, somente com a teoria do labelling approach ${ }^{3}$, é que o problema da definição do delito, considerado realidade social e com todas as implicações políticas, econômicas e sociais que revela, foi definido como o ponto central de uma teoria crítica da criminalidade. "As questões centrais do pensamento criminológico, a partir desse momento histórico, deixam de referir-se ao crime e ao criminoso, passando a voltar sua base de reflexão ao sistema de controle social e suas consequências (...)" (SHECAIRA, 2011, p.287).

O labelling approach, surgido nos Estados Unidos, no final da década de 1950, situou-se no horizonte de pesquisa dominado por duas correntes da sociologia americana,

\footnotetext{
${ }^{3}$ O labelling approach é designado também como teoria do interacionismo simbólico, do etiquetamento, da rotulação, do paradigma da reação social, do controle ou da definição.
} 
estreitamente ligadas entre si, quais sejam o "interacionismo simbólico" e a "etnometodologia":

Segundo o interacionismo simbólico, a sociedade - ou seja, a realidade social- é constituída por uma infinidade de interações concretas entre indivíduos, aos quais um processo de tipificação confere um significado que se afasta das situações concretas e continua a estender-se através da linguagem. Também segundo a etnometodologia, a sociedade não é uma realidade que se possa conhecer sobre o plano objetivo, mas o produto de uma "construção social", obtida graças a um processo de definição e de tipificação por parte dos indivíduos e de grupos diversos. E, por consequência, segundo o interacionismo e etnometodologia, estudar a realidade social (por exemplo, o desvio) significa essencialmente, estudar estes processos, partindo dos que são aplicados a simples comportamentos e chegando até as construções mais complexas, como a própria concepção de ordem social. (BARATTA, 2002, p.87)

Para uma exata compreensão de toda essa mudança de perspectiva trazida pelo labelling approach, imprescindível é outra observação formulada por Alessandro Baratta (2002, p.88):

Os criminólogos tradicionais examinam problemas do tipo "quem é criminoso?", "como se torna desviante?", "em quais condições um condenado se torna reincidente?", "com que meios se pode exercer controle sobre o criminoso?". Ao contrário, os interacionistas, como em geral os autores que se inspiram no labelling approach, se perguntam: "quem é definido como desviante?", "que efeito decorre desta definição sobre o indivíduo?", "em que condições este indivíduo pode se tornar objeto de uma definição?" e, enfim, "quem define quem?".

Diante dessas novas indagações, a teoria do labelling formula suas respostas, principalmente, a partir da construção conceitual das noções de desvio, reação social, agências de controle, etiquetamento, processos de criminalização e desvios primários e secundários, baseando-as em aspectos sociológicos, psicológicos e sociolingüísticos. 
A tese do desvio como criação da própria sociedade foi desenvolvida, primeiramente, por Howard Becker ${ }^{4}$ (2008, p. 21-22):

(...) os grupos sociais criam desvio ao fazer as regras cuja infração constitui desvio, e ao aplicar essas regras a pessoas particulares e rotulá-las como outsiders. Deste ponto de vista, o desvio não é uma qualidade do ato que a pessoa comete, mas uma consequência da aplicação por outros fazem de regras e sanções a um "infrator". O desviante é alguém a quem esse rótulo foi aplicado com sucesso; o comportamento desviante é aquele que as pessoas rotulam como tal.

Assim, "o labelling desloca o problema criminológico do plano da ação para o da reação (dos bad actors para os powerful reactors), fazendo com que a verdadeira característica comum dos delinquentes seja a resposta das audiências de controle" (SHECAIRA, 2011, p.306), ou seja, para haver criminalidade é necessário, portanto, o desencadeamento de uma reação social correspondente, pois o simples desvio não é suficiente. Nesse sentido:

Esta direção de pesquisa parte da consideração de que não se pode compreender a criminalidade se não se estuda a ação do sistema penal, que a define e reage contra ela, começando pelas normas abstratas ${ }^{5}$ até a ação das instâncias oficiais (polícia, juízes, instituições penitenciárias que as aplicam), e que, por isso, o status social de delinquente pressupõe, necessariamente, o efeito da atividade das instâncias oficiais de controle social da delinquência, enquanto não adquire esse status aquele que, apesar de ter realizado o mesmo comportamento punível, não é alcançado, todavia, pela ação daquelas instâncias. Portanto, este não é considerado e tratado pela sociedade como "delinquente". (BARATTA, 2002, p.86)

Por conseguinte, diante de um primeiro comportamento desviante (desvio primário) surge a reação social ou a punição em relação correspondente, estas que possuem, frequentemente, a função de um commitment to deviance, gerando, através de

\footnotetext{
${ }^{4}$ Um dos principais teóricos americanos do labelling. A ele se deve, principalmente, a ideia do processo de atribuição da "etiqueta" ou "rótulo" de criminosos a certos indivíduos. Segundo ele, pra um ato ser ou não desviante depende de como as pessoas reagem a ele (BECKER, 2008, p. 24).

${ }^{5}$ A elaboração das normas abstratas ou processo de criminalização primária corresponde ao processo de criação das normas penais, em que se definem os bens jurídicos a serem protegidos, as condutas que serão criminalizadas e as respectivas penas numa determinada sociedade (ANDRADE, 1996, p.282).
} 
uma mudança da identidade social do indivíduo assim estigmatizado, uma tendência a permanecer no papel social no qual a estigmatização o introduziu (BARATTA, 2002, p.89). Howard Becker (2008, p. 44) afirma que:

Tratar uma pessoa como se ela fosse em geral, e não em particular, desviante produz uma profecia auto-realizadora. Ela põe em movimento vários mecanismos que conspiram para moldar a pessoa segundo a imagem que os outros têm dela.

Os desvios sucessivos ou desvios secundários à reação social - compreendida a incriminação e a pena - são fundamentalmente determinados pelos efeitos psicológicos que tal reação produz no indivíduo objeto da mesma (BARATTA, 2002, p.89). Nesse contexto, Shecaira (2011, p.312-313) bem esclarece sobre os efeitos que o etiquetamento ou estigmatização opera no indivíduo:

Uma das maiores consequências do processo de desviação é o agente ser capturado pelo papel desviante. Este mergulho interativo será chamado pelos teóricos do labelling de role engulfment. No que concerne ao mergulho no papel desviado, podem-se destacar dois principais pontos de referência: como os outros definem $o$ ator e como $o$ ator se define. De maneira bastante cruel, pode ser dito que, à medida que o mergulho no papel desviado cresce, há uma tendência para que o autor do delito defina-se como os outros o definem. A personalidade do agente se referenciará no papel desviado ainda que ele se defina como não desviado. As dificuldades são ainda mais pronunciadas quando o agente, embora negue o papel desviado, é, cada vez, identificado por terceiros pela conduta classificada como desviada. Surgirá uma espécie de subcultura delinquente facilitadora da imersão do agente em um processo em espiral que traga o desviante cada vez mais para a reincidência.

Portanto, a reação - por isso, paradigma da reação social- é fundamental para definir a conduta como desviada. Assim, com o labelling approach, ao invés do uso dos termos criminalidade e criminoso ou criminoso nato, utiliza-se processo de criminalização e criminalizado, pois sem "criminalização ${ }^{6}$ não há crime" (ZAFFARONI; PIERANGELI, 2007, p. 141).

\footnotetext{
${ }^{6} \mathrm{O}$ interesse do paradigma da reação social se volta para os mecanismos através dos quais as normas penais são criadas pelo legislador (criminalização secundária), aplicadas pela polícia e juízes
} 
Assim, um dos grandes triunfos da teoria do etiquetamento foi a desconstrução do princípio da prevenção e ressocialização da pena, aclamado pela ideologia da defesa social, como aponta Vera Andrade (1996, p.282):

Relacionando-se com um mais vasto pensamento penalógico e criminológico crítico sobre os fins da pena, este nível de investigação põe em evidência que a intervenção do sistema penal, em especial as penas privativas de liberdade, ao invés de exercerem um efeito reeducativo sobre o delinquente, determinam, na maior parte dos casos, uma consolidação de uma verdadeira e própria carreira criminal, lançando luz sobre os efeitos criminógenos do tratamento penal e sobre o problema não resolvido da reincidência. De modo que seus resultados sobre o "desvio secundário" e sobre as carreiras criminosas representam a negação da concepção reeducativa da pena e da ideologia do tratamento.

É por todas as exposições trazidas acima, que a teoria do etiquetamento supera a ideia do desvio e da criminalidade como realidades ontológicas e demonstra que, na verdade, ambos são resultados da reação social - operadas pelas agências formais e informais de controle - diante de uma conduta desviante que atribui a "etiqueta" de criminoso a certos indivíduos. Daí, uma vez rotulado como criminoso, o indivíduo estigmatizado tem alterada a sua identidade social e, na quase totalidade dos casos, inicia uma desviação ou delinquência secundária que o faz permanecer num constante estado de reincidência.

O cerne da Criminologia da reação social passou, assim, para os processos de criminalização aos quais são submetidos os delinquentes, ao contrário da Criminologia Positivista que tinha estes como seu próprio objeto de estudo.

Todas essas observações trazidas pelo labelling approach foram essenciais para a percepção crítica do fenômeno criminal. No entanto, por se concentrar nas complexas

(criminalização secundária) e, enfim, executadas pelas instituições penitenciárias (criminalização terciária). Pode-se dizer que a criminalização provém da atuação "etiquetante" dessas agências perante o indivíduo rotulado. 
ideias de processos de criminalização e reação social, o labelling não logrou explicar as razões sócio-políticas pelas quais alguns indivíduos eram definidos como criminosos e outros não o eram. Para explicar tais razões é que surge a Criminologia Crítica ${ }^{7}$.

\subsubsection{CRIMINOLOGIA CRÍTICA ${ }^{8}$ :}

O pensamento criminológico crítico, surgido em meados da década de 1970, propôs a construção de uma teoria materialista, ou seja, econômico-política do desvio, dos comportamentos socialmente negativos e da criminalização, utilizando-se de instrumentos conceituais e hipóteses elaboradas no âmbito do marxismo ${ }^{9}$, bem como de um vasto trabalho de observação empírica que forneceram dados assaz importantíssimos (BARATTA, 2002, p.159). Na perspectiva da criminologia crítica, a criminalidade não é mais uma qualidade ontológica de determinados comportamentos e de determinados indivíduos, mas constitui um bem negativo distribuído desigualmente conforme a hierarquia dos interesses fixada no sistema sócio-econômico e conforme a desigualdade social dos indivíduos (BARATTA, 2002, p.161).

Partiu, então, a Criminologia Crítica para o estudo do sistema penal, relacionando a ideia da seletividade à desigualdade social, política e econômica. Assim, responde ao questionamento - deixado em aberto pelo labelling- "por que certos indivíduos são criminalizados?", nos seguintes termos: porque eles são selecionados pelo sistema penal a partir de um critério sócio-econômico que diferencia os indivíduos.

\footnotetext{
${ }^{7}$ Segundo Baratta, a passagem do labelling approach para a criminologia crítica ocorre lentamente e sem uma verdadeira e própria solução de continuidade. (BARATTA, 2002, p.159)

8 Também conhecida sob as denominações de criminologia radical, criminologia marxista e nova criminologia.

${ }^{9}$ Baratta adverte que, diante da relação problemática entre a Criminologia e Marxismo, a construção teórica da Criminologia Crítica não foi derivada exclusivamente da interpretação dos textos marxianos. (BARATTA, 2002, p.159)
} 
Evidenciando, portanto, a contradição ${ }^{10}$ entre a igualdade formal dos indivíduos, como sujeitos de direito no sistema jurídico abstrato, e a desigualdade substancial, quanto às posições que ocupam na escala social, e que, quanto a esta última, se manifesta em relação às chances de serem definidos e controlados como desviantes enquanto privilegia os interesses das classes dominantes. Nesse sentido, cabíveis estas observações:

As maiores chances de ser selecionado para fazer parte da
"população criminosa" aparecem, de fato, concentradas nos
níveis mais baixos da escala social (subproletariado e grupos
marginais). A posição precária no mercado de trabalho
(desocupação, subocupação, falta de qualificação profissional) e
defeitos de socialização familiar e escolar, que são características
dos indivíduos pertencentes aos níveis mais baixos, e que na
criminologia positivista e em boa parte da criminologia liberal
contemporânea são indicados como as causas da criminalidade,
revelam ser, antes, conotações sobre a base das quais o status do
criminoso é atribuído. (BARATTA, 2002, p.165)

Tal desigualdade pode ser percebida em todos os mecanismos dos processos de criminalização. Na criminalização primária, quando tende a imunizar os comportamentos socialmente danosos, típicos dos indivíduos pertencentes às classes dominantes e ligados funcionalmente à existência da cumulação capitalista; enquanto se dirige à criminalização de desvios típicos das classes subalternas (BARATTA, 2002, p.165). Na criminalização secundária, acentua-se o caráter seletivo do sistema penal abstrato. Isso porque os preconceitos e estereótipos que guiam a ação tanto dos órgãos investigadores como dos órgãos judicantes os levam a procurar a verdadeira criminalidade principalmente naqueles estratos sociais dos quais é "normal” esperá-la (BARATTA, 2002, p.176). Além disso, "a distância linguística que separa julgadores e julgados, a menor possibilidade de desenvolver um papel ativo no processo e de servir-se do trabalho de advogados prestigiosos, desfavorecem os indivíduos socialmente mais débeis" (BARATTA, 2002, p.177). Ainda, a pena detentiva é prioritariamente aplicada em desfavor dos marginalizados, pois se tende a considerá-la como mais adequada àqueles porque é

\footnotetext{
${ }^{10}$ Segundo Baratta, a Criminologia Crítica toma emprestado dos textos marxistas a crítica da contradição entre a igualdade formal e a desigualdade substancial (posição dos indivíduos reais na relação social de produção) desenvolvida no âmbito do direito privado para aplicá-la no âmbito do direito penal. (BARATTA, 2002, p.163/164)
} 
menos comprometedora para o seu status social já baixo e porque entra na imagem normal do que frequentemente acontece a indivíduos pertencentes a tais grupos sociais (BARATTA, 2002, p.178). Por fim, na criminalização terciária, que compreende os mecanismos de execução da pena - principalmente, o cárcere - ou das medidas de segurança, é que se acentuará o processo de reprodução das desigualdades. Isso porque os institutos de detenção produzem efeitos negativos contrários à reeducação e à reinserção dos condenados, pois, ao estigmatizá-los, favorecem a reincidência e a configuração das carreiras criminosas (BARATTA, 2002, p.183-184), como será melhor abordado no próximo capítulo.

Portanto, diante dessas observações trazidas pelo novo pensamento criminológico, desconstruiu-se o princípio da igualdade, defendido pela ideologia da defesa social, concluindo-se em direção totalmente oposta, conforme esclarece Baratta (2002, p.162):

a) o direito penal não defende todos e somente os bens essenciais, nos quais estão igualmente interessados todos os cidadãos,e quando pune as ofensas aos bens essenciais o faz com intensidade desigual e de modo fragmentário; b) a lei penal não é igual para todos, o status de criminoso é distribuído de modo desigual entre os indivíduos; c) o grau efetivo de tutela e a distribuição do status de criminoso é independente da danosidade social das ações e da gravidade das infrações à lei, no sentido de que estas não constituem a variável principal da reação criminalizante e da sua intensidade. A crítica se dirige, portanto, ao mito do direito penal como direito igual por excelência. Ela mostra que o direito penal não é menos desigual do que os outros ramos do direito burguês, e que, contrariamente a toda aparência, é o direito desigual por excelência.

Ao aprofundamento desta desigualdade do Direito Penal e dos mecanismos de criminalização do sistema penal, a Criminologia Crítica defende, no intuito de transformação ou superação do direito penal desigual, a adoção de uma política penal alternativa, sob o ponto de vista dos interesses das classes subalternas, no setor do controle social desvio.

Segundo Baratta, a linha principal de tal política alternativa é a contração ao máximo e, no limite, a superação do sistema penal (2002, p.183-184). É, aqui, dentre 
outras, nesta proposta de contração do sistema penal - principalmente, quanto à aplicação das penas detentivas- é que se encontra uma permeabilidade entre a Criminologia Crítica e as concepções restaurativas. Assim, as propostas da justiça restaurativa serviriam como a complementação prática, ou seja, como meio para atingir tal fim, qual seja: a redução das desigualdades geradas pelo sistema penal. Nesse contexto, têm-se, em resumo, as seguintes propostas ${ }^{11}$ formuladas por Alessandro Baratta (2002, p.201-205):

1) A necessidade de um tratamento diferenciado para os comportamentos socialmente negativos praticados pelos membros das classes subalternas e da classe dominante, pois os primeiros são resultados das contradições que caracterizam a dinâmica das relações de produção e distribuição, envolvendo indivíduos socialmente desfavorecidos, enquanto que os segundos devem-se às relações funcionais que ocorrem entre processos legais e ilegais de acumulação e circulação de capital, e entre estes e a esfera política. Assim, pretende-se uma política criminal que não seja meramente de "substitutivos penais", mas por uma política de grandes reformas sociais e institucionais para o desenvolvimento da igualdade, da democracia, de formas alternativas e mais humanas de vida comunitária e civil;

2) Por uma ampliação e reforço da tutela penal quanto às áreas de interesse essencial para a vida dos indivíduos e da comunidade, tais como saúde, segurança do trabalho, meio ambiente, dirigindo-se a repressão penal para o confronto da criminalidade econômica, organizada e dos órgãos estatais. Por outro lado, pela despenalização dos tipos penais que foram concebidos sob a concepção autoritária e ética do Estado, bem como aliviar a pressão negativa do sistema punitivo sob as classes subalternas. Em todos os casos, é preciso dar justa importância a meios alternativos de controle, não menos rigorosos, que podem se revelar, em muitos casos, mais eficazes. Ainda, quanto à estratégia de despenalização, esta significa também a adoção de forma de controle legal

\footnotetext{
${ }^{11}$ Baratta formula, de forma aprofundada, quatro indicações de caráter diretivo para uma política criminal das classes subalternas. No entanto, este trabalho deter-se-á somente, dentro de tais indicações, aos pontos propostos que permitem uma maior aproximação com a Justiça Restaurativa. Ressalta-se que, uma vez que o autor não aborda os meios concretos para se atingir tais estratégias, as práticas restaurativas ganham, assim, espaço dentro da construção desta política alternativa.
} 
não estigmatizantes (sanções administrativas ou civis) ao invés de sanções penais, e, mais ainda, o encaminhamento de processos alternativos de socialização do controle do desvio e de privatização dos conflitos, nas hipóteses em que isso seja possível e oportuno;

3) Pela abolição do cárcere, ainda que sejam diferenciadas as etapas de aproximação deste objetivo. Assim, gradualmente, busca-se o alargamento do sistema de medidas alternativas, das formas de suspensão e liberdade condicional da pena, dos regimes de semi-liberdade, dos regimes de permissões e reavaliação constante, em todos os sentidos, e do trabalho carcerário; bem como, a abertura do cárcere para a sociedade mediante a colaboração das entidades locais, dos próprios presos e do movimento operário;

4) Por uma batalha cultural e ideológica para o desenvolvimento de uma consciência alternativa no campo do desvio e da criminalidade, buscando-se a mudança do senso comum em relação ao controle estatal, com o fim de despertar a comunidade para as contradições da sociedade capitalista e do sistema penal. Assim, intenta-se a superação da ideia da defesa social, esta vinculada à ideologia das classes dominantes, pela opinião pública que persiste mesmo nas classes subalternas;

A esta altura, torna-se possível, ainda que diante de uma exposição breve, a compreensão da importância das contribuições trazidas pela Criminologia da reação social (principalmente, o labelling approach e Criminologia Crítica) para um posicionamento crítico perante o Direito Penal posto e a atuação do sistema penal.

Foram tais teorias que perceberam e formularam, com fortes bases empíricas, as noções de processos de criminalização, seletividade, estigmatização, desvio secundário e desigualdade substancial, estas que, indubitavelmente, foram propulsoras, entre outras, das práticas restaurativas. Assim, uma vez desvendado o sistema penal, as propostas restaurativas se alicerçaram naquelas noções para justificarem seus procedimentos, ou seja, a justiça restaurativa surge para tentar evitar que aquelas noções se perpetuem na prática dos sistemas penais.

Ainda, quanto às propostas da política alternativa proposta por Baratta, percebe-se que nesta foram formuladas, dentre outras, as seguintes ideias: "para o desenvolvimento 
de formas alternativas e mais humanas de vida comunitária e civil", "formas de controle legal não estigmatizantes", "privatização de conflitos", "meios alternativos de controle mais eficazes", que permitem uma interpretação no sentido de compatibilizar as propostas da Criminologia Crítica com as concepções restaurativas. Isso porque, como se verá em outro capítulo, a justiça restaurativa abarca, dentre outros objetivos, todas essas ideias.

Portanto, diante de todas as considerações expostas, não há como desconhecer a existência de um vínculo teórico entre a justiça restaurativa e o paradigma da reação social construído pela Criminologia Crítica. Por mais que possa se reconhecer, obviamente, os distanciamentos ${ }^{12}$ e limitações conceituais com as atuais práticas restaurativas, é inegável que aquele paradigma serviu de moldura teórica para amparar a práxis restaurativa, principalmente, no que tange à preocupação com a não estigmatização do indivíduo que pratica uma conduta criminalizada, evitando-se, assim, a desviação secundária e, consequentemente, a reincidência e encarceramento em massa.

\subsection{POLÍtICAS CRIMINAIS E JUSTIÇA RESTAURATIVA: O PENSAMENTO ABOLICIONISTA}

Entende-se a corrente abolicionista, que também se utiliza de conceitos do labelling, como uma das vertentes da Criminologia Crítica ${ }^{13}$, que foi lançada com os posicionamentos inovadores do escandinavo Thomas Mathiesen, em 1971, e de Nils Christie, Herman Bianchi e Louk Hulsman, que, logo, foram irradiados por toda Europa.

\footnotetext{
${ }^{12}$ Juliana Cardoso Benedetti (2006) concluiu que o confronto, mesmo que perfunctório, entre os postulados da criminologia da reação social e os traços gerais dos modelos atuais de justiça restaurativa não demonstra a total compatibilidade entre ambos.

${ }^{13}$ Nesta época a Criminologia é marcada por uma divisão: alguns integrantes da chamada "Nova Criminologia", nos anos 1960, tornaram-se realistas de esquerda, outros criminólogos críticos uniram-se à perspectiva abolicionista, enquanto outros adotaram posição intermediária, defendendo o Minimalismo, ou Direito Penal Mínimo (LARRAURI apud PORCIUNCULLA, 2009, p. 37)
} 
Em suma, o Abolicionismo ${ }^{14}$, como um todo, vai defender a abolição - por isso, abolicionismo- não apenas das prisões, mas da própria ideia de castigo e de qualquer forma punitiva. Neste ponto, Gabriel Anitua (2008, p.695) esclarece:

Embora seu nome (abolicionismo) seja tomado da luta histórica contra a escravidão, e contra a pena de morte, nesses anos, e no interior da Criminologia Crítica, essa denominação seria atribuída à deslegitimação mais radical do sistema carcerário e da própria lógica punitiva. Esta reflexão antipunitiva estava estreitamente relacionada às reivindicações teóricas e práticas de alguns criminólogos de antiga tradição nos países escandinavos e na Holanda.

O ponto comum entre os autores dessa corrente, além da abolição do cárcere, é o não reconhecimento da legitimidade do direito penal, porque não aceitam moralmente a justificativa de seus fins frente ao sofrimento que provoca e/ou porque consideram vantajosa a substituição da sanção punitiva por meios pedagógicos ou de controle social informal (FERRAJOLI apud PALLAMOLLA, 2009, p.39). A ideia é que o Direito e sistema penal servem tão somente apenas para reproduzir as desigualdades e injustiças sociais. Apesar dos pontos em comum, os autores, como se verá adiante, distinguem-se entre si pelas peculiaridades teóricas que desenvolveram.

Thomas Mathiesen, influenciado pelo pensamento marxista, estava convencido da existência da vinculação entre sistema penal e capitalismo e, assim, defendia a necessidade e a plausibilidade de os cárceres serem abolidos e de que a sociedade podia se organizar de forma tal que as prisões não tivessem mais razão de ser. Esta meta seria alcançada, sem um ponto final, em diferentes etapas e apelando sempre à racionalidade comunicativa. Aqui, estava a chave da reforma penal e do fim dos preconceitos: a comunicação. Uma comunicação alternativa àquela que hoje atua no intuito de desinformar e negar a realidade, pois sujeitos verdadeiramente informados certamente não apoiariam o sistema posto e o encarceramento humano (ANITUA, 2008, p.704).

\footnotetext{
${ }^{14} \mathrm{Na}$ verdade, como assevera Shecaira (2011, p. 366-368), não existe um único Abolicionismo. Três são as principais matizes ideológicas do Abolicionismo: a anarquista, a marxista e liberal/cristã. No presente trabalho, sem o aprofundamento dessas diferenciações do pensamento abolicionista, serão enfatizadas apenas as principais observações, capazes de traduzir as principais ideias e que possuem maior pertinência com as práticas restaurativas, formuladas por esta corrente.
} 
Segundo este abolicionista, a pena do cárcere é incompatível com uma organização democrática, pois os castigos e os delitos não podem ser medidos e nem a "justiça" pode ser medida em termos de tempo, motivo pelo qual se afirma que a prisão não faça justiça. Sustenta, ainda, a necessidade de opor resistência e, gradualmente, ir construindo um espaço público alternativo e melhor; que, além da exclusão do punitivo, abranja os princípios de inclusão política, econômica e social de toda a humanidade. Esse novo modelo seria um modelo participativo (ANITUA, 2008, p.706). Dentro deste modelo de participação, Mathiesen abordava a importância da vítima:

A vítima resulta sendo vítima também do sistema punitivo. Ademais, não raro, é a vítima que trará uma luz para a solução da pendência existente com o réu. No mais das vezes vítimas de um processo não diferenciam uma questão civil da penal; muitas vezes não têm qualquer interesse em perseguir quem quer que seja (MATHIENSE apud SHECAIRA, 2011, p.373).

Nesse contexto de incentivo à participação comunitária, o abolicionista Nils Christie se destaca e apresenta um modelo participativo de pequenas comunidades nas quais as pessoas se controlam informalmente e interagem na resolução dos problemas. Isso porque, o Estado expropria o conflito das partes e ao mesmo tempo da comunidade, gerindo-o em benefício próprio. Desse modo, aposta em formas alternativas de controle social nas quais se passa pela recuperação dos conflitos pelas partes originais (ANITUA, 2008, p.707). Por conseguinte, propõe a construção de formas de justiça participativa e comunitária capazes de abdicar do uso da sanção de privação ou restrição de liberdade e utilizar a reparação ou indenização do dano por meio da composição do conflito (CARVALHO apud PALLAMOLLA, 2009, p.41). Nesse contexto, vai advogar por um encontro $^{15}$ entre vítima direta e ofensor (LARRAURI, 2009, p.168). Eis a tradução do modelo participativo defendido por este abolicionista:

A ideia básica de Christie é que retirar das pessoas a possibilidade de administrar seus próprios conflitos é uma

\footnotetext{
${ }^{15}$ A construção teórica de Nils Christie representa um marco para todo o movimento de justiça restaurativa, principalmente, quanto à sua vertente procedimental, assentada no encontro entre os envolvidos no conflito. Tais ideias foram e continuam sendo a base de muitos programas de Justiça Restaurativa, embora a imensa maioria destes, na atualidade, tenham posto de lado o ideal abolicionista. (ZAGALLO, 2010, p.33).
} 
grande perda para a sociedade como um todo. Primeiro para a vítima, em razão da ansiedade que o crime lhe gera e o sistema penal não é capaz de atender. Para o ofensor, por lhe retirar a possibilidade de reparar a ofensa cometida. E, por fim, para toda a comunidade, que perde boas oportunidades para a discussão de normas, costumes, valores, concepções de justiça e do próprio direito. A devolução dos conflitos às pessoas é, desse modo, uma forma de restabelecer e fortalecer os laços comunitários. (ZAGALLO, 2010, p.32).

O professor holandês Hulsman ${ }^{16}$ define os conflitos entre as pessoas, ou seja, as situações delituosas como "situações problemas ${ }^{17}$ ". Essa nova denominação proposta abre um leque para outros desfechos possíveis, ao invés da única opção de castigo, para restabelecer a paz rompida pelo delito através de procedimentos informais e de mediação que coloca frente a frente ofensor e vítima (HULSMAN apud PALLAMOLLA, 2009, p.43). A ideia é que "buscar com outros uma solução é, já em si, uma atividade libertadora" (HULSMAN apud SHECAIRA, 2011, p.368).

Enfim, este abolicionista, diante da ineficácia do sistema penal, pretende a sua completa extinção ${ }^{18}$ e explica que o Estado apropria-se do conflito das pessoas diretamente envolvidas, ofensores e vítimas, que não são escutadas pelos agentes do sistema penal:

Segundo Hulsman, as partes envolvidas no problema não podem influir em sua resolução ou continuação, uma vez que se é definido como "delito" e dele se encarregam os "especialistas" do sistema penal. O resultado disso, além de não satisfazer a nenhuma das partes envolvidas no problema, gera novos

\footnotetext{
${ }^{16}$ Hulsman e Bianchi construíram suas teorias e críticas a partir de parâmetros mais morais do que técnicos; moralidade esta que adquiria tintas religiosas, taoístas, budistas e também cristãs. Enquanto Christie e Mathiesen, representantes do Abolicionismo escandinavo radical, embora apontem igualmente para modelos comunitários, partem de pressupostos distantes das vertentes fenomenológica e religiosa dos primeiros (ANITUA, 2008, p. 702). Hulsman, assim como Christie, pode-se dizer que foram os autores que mais contribuíram à perspectiva restaurativa (PALLAMOLLA, 2009, p. 41).

${ }^{17}$ Segundo este abolicionista, o termo delito é inadequado para descrever situações tão diversas, devendo, assim, ceder lugar à expressão situações problemáticas.

${ }_{18}$ "Anyar de Castro expõe sua preocupação quanto à viabilidade da proposta abolicionista, mais especificamente a de Hulsman, nos países latino-americanos. Segundo a autora, para que uma sociedade possa prescindir do sistema penal é necessário um alto nível de democracia em sua estrutural social, econômica e cultural, o que não se vê nos países periféricos, estando, assim, inviabilizada a proposta abolicionista, mesmo se introduzida de forma lenta." (PALLAMOLLA, 2009, p.45)
} 
problemas, como a estigmatização, a marginalização social, etc. (...) Dever-se-ia tentar compreender a realidade social a partir do ponto de vista dos indivíduos e não de acordo com as definições da realidade e do marco conceitual burocrático que o sistema penal assume (ANITUA, 2008, p. 699).

(a intenção da vítima é) falar do prejuízo sofrido, simplesmente com a esperança de fazer cessar a situação que as incomoda e recuperar seu dinheiro, se for o caso. O que querem essas vítimas é obter reparação e reencontrar a paz, assim como encontrar alguém que as escute com paciência e simpatia (HULSMAN; CELIS apud PALLAMOLLA, 2009, p.42)

Aproveitando-se da ideia de atividade libertadora, citada anteriormente, para o abolicionista Bianchi fazer justiça implica liberar as pessoas - ofensores, vítimas, acusadores, defensores, enfim, todos os envolvidos - das consequências dos conflitos, ou que essas consequências possam ser reparadas tanto quanto possível (ZAGALLO, 2010, p.29):

Enquanto se mantiver intacta a ideia de castigo como uma forma aceitável de reagir diante do delito, não se pode esperar nada de bom de uma simples reforma do sistema. Em resumo, necessitamos de novo sistema alternativo de controle do delito que não se baseie em um modelo punitivo, mas sim em outros princípios legais e éticos, de forma tal que a prisão ou outro tipo de repressão física torne-se essencialmente desnecessária. (BIANCHI apud ANITUA, 2008, p.696)

Nesse contexto, este autor defendia um sistema de justiça que protegesse o estigmatizado, que lhe oferecesse oportunidades de sentir e demonstrar remorso. Os princípios dessa justiça são os da reconciliação e do restabelecimento da paz, que seriam aceitos em seguida em todo movimento da justiça restaurativa (ANITUA, 2008, p.697).

Enfim, em linhas gerais, dentre as principais preocupações do discurso abolicionista, encontram-se: a perda da liberdade e autonomia do indivíduo por obra do Estado; a construção de um sistema em que os homens se ocupariam de seus próprios conflitos; a dor, moral e física, desnecessária imposta pela pena aos autores de delitos e que se estende às famílias destes; desnecessidade de uma intervenção tão radical do sistema penal, principalmente, quanto à pena de prisão; a estigmatização e seletividade 
produzidas pelo sistema penal discriminatório; a despreocupação com o que ocorrerá com o acusado e a vítima; a concepção daqueles que praticam delitos como verdadeiros "inimigos" do direito penal e, enfim, a extrema burocratização e formalidade do sistema penal que se "opõe à estrutura mais informal da sociedade civil, que muitas vezes facilita encontros cara a cara, os quais podem agilizar a solução dos conflitos entre as partes envolvidas" (SHECAIRA, 2011, p. 372). Assim, percebe-se que, a partir das críticas abolicionistas ao sistema penal, acrescentaram-se propostas de alternativas e outros modos de regulação dos conflitos, com a inclusão da vítima na negociação para solucionar o conflito e buscar a reforma do ofensor (LARRAURI apud PALLAMOLLA, 2009, p.44).

Portanto, a partir dos posicionamentos abolicionistas dos autores mencionados, bem como das linhas gerais traçadas, percebe-se que o discurso abolicionista compatibiliza-se, na quase totalidade de seus argumentos, com o modelo restaurativo. Diz-se na quase totalidade porque no que tange à presença do Estado, a justiça restaurativa não a renega totalmente. Nesse contexto, Elena Larrauri (2009, p.168) explica:

Por que então, a partir da década de noventa, fala-se em justiça restaurativa e não em "abolicionismo"? O motivo fundamental é, em minha opinião, que o Abolicionismo pretende que as vítimas recuperem o conflito com o ofensor e mesmo quando prevê a intervenção de terceiras partes como mediadores, estes são "mediadores vicinais". Isto implica que as propostas do abolicionismo sejam uma alternativa ao sistema penal atual, posto que ou defende que a comunidade recupere sua capacidade de solucionar seus conflitos ou, alternativamente, advoga pela resolução dos conflitos por meio do direito civil. [...]. Contudo, a justiça restaurativa [...] admitiu que pode coexistir com a justiça penal, visto que esta pode tornar mais eficaz o acordo alcançado nas conferências restaurativas.

Ainda, segundo Braithwaite, existem importantes diferenças de política criminal entre Justiça Restaurativa e Abolicionismo, pois enquanto a justiça restaurativa admite a utilização do cárcere para um número reduzido de delitos e segue conferindo importância à conservação das garantias processuais e penais, o Abolicionismo propõe não só uma alternativa à pena de prisão, mas uma total substituição do atual processo penal e, em sua 
concepção mais externa, uma alternativa ao sistema penal (PALLAMOLLA, 2009, p. 35). Também a justiça restaurativa mantém o conceito de delito, enquanto o Abolicionismo sugere prescindir dele (LARAURRI, 2009, p.168).

O Abolicionismo, assim, propôs um novo vocabulário, que foi além do desenvolvido pela Criminologia Crítica, recuperando outras expressões tais como reparação, conflito, situações problemáticas, restauração, importância da vítima, estrutura mais informal, resolução humana dos conflitos, libertação de traumas e medos, satisfação das partes e demonstração de sentimento e remorso no intuito de desenhar novas alternativas. Não obstante as diferenças ligeiramente traçadas, o modelo restaurativo, indubitavelmente, se encaixa no desenho dessas novas alternativas buscadas pelos abolicionistas. Como atestam Hassemer e Conde (2011, p.300):
Não cabem dúvidas de que a proposta de que determinadas formas de criminalidade resolvam-se por acordos entre seus protagonistas e com a reparação do dano causado é uma das teses defendidas pelos abolicionistas que mais atenção merece e que maiores perspectivas pode oferecer para um solução não- punitiva aos conflitos penais no futuro.

Por fim, todas essas correntes, desenvolvidas até aqui, de contestação das instituições repressivas - Labelling, Criminologia Crítica e Abolicionismo - nutrem a reflexão para o desenvolvimento de um movimento que recomenda o recurso para uma justiça diferente, humanista e não punitiva (JACCOUD, 2005, p.165).

\subsection{VITIMOLOGIA}

O crescente interesse criminológico pela vítima do delito deu lugar ao nascimento de um novo ramo dentro da Criminologia, que, inclusive, pretende-se como ciência autônoma: a Vitimologia (HASSEMER; CONDE, 2011, p. 131). 
A Vitimologia é a corrente de cunho científico que se desenvolveu, no período após a Segunda Guerra Mundial ${ }^{19}$, década de 1940, acerca das vítimas de delitos. Primeiramente, este conhecimento preocupou-se, seguindo a tradição positivista que caracterizava a Criminologia da época, com as razões da vitimização e com os fatores ou causas que predispõem os indivíduos a tornarem-se vítimas. Mais tardiamente, é surgirá o interesse quanto aos efeitos da vitimização (JACCOUD, 2005, p.165).

Este primeiro momento da Vitimologia, no qual se tentou desenvolver uma etiologia da vitimização, foi alvo de inúmeras críticas - tal como foi a Criminologia Positivista; além disso, não foi ao encontro das reivindicações do movimento de vítimas. Este movimento político, ressurgido nas décadas de 60 e 70, principalmente nos Estados Unidos e Inglaterra, preocupado quanto à posição da vítima no sistema penal (PALLAMOLLA, 2009, p.48).

Posteriormente, nos anos 1980, o movimento das vítimas e a Vitimologia aproximam-se e "vão sensibilizar profundamente os críticos teóricos do modelo retributivo para as necessidades, mas sobretudo para a ausência da vítima no processo penal" (JACCOUD, 2005, p.165). Nesse contexto:

A força dos movimentos das vítimas, desde a década de oitenta, reflete numerosas mudanças sociais, expostas por Bottoms, como são fundamentalmente, a crise de legitimidade do sistema penal, fruto, provavelmente do seu caráter burocrático, não participativo e inefetivo, que acarreta o surgimento de numerosos intentos de reforma e mudança, e uma mudança de percepção do delito, que tende a deixar de conceber-se como uma ofensa ao Estado para se concentrar no dano realizado às vítimas individuais (LARRAURI, 2009, p. 169).

\footnotetext{
19 Ao fim da Segunda Guerra Mundial, o espanto provocado pela revelação do holocausto judeu, acompanhado da necessidade de compreender como tais atrocidades foram possíveis - ainda, diante de forte sofrimento imposto às vítimas judias, de modo a evitar sua repetição, propiciaram uma maior atenção às vítimas de um modo geral (ZAGALLO, 2010, p.16). Larrauri explica que a vitimologia ganha força e destaque nos anos 80 , porém o seu verdadeiro início não se deu nesta época, mas sim com a publicação da obra The criminal and his victim, em 1948 - por isso, período pós-guerra - de Von Hentig de caráter extremamente positivista. Tal obra apontava os graus de culpabilidade das vítimas nos delitos (PALLAMOLLA, 2009, p.47).
} 
Nesta nova fase da Vitimologia, já mais avançada, esta se ocupou, além da defesa dos direitos e interesses das vítimas, com o estudo dos processos de vitimização primário, secundário ${ }^{20}$ e terciário-, seguindo um paralelismo com o paradigma da reação social, ou seja, do porquê que alguns indivíduos têm mais possibilidades de chegar a serem vítimas de delitos que outros como consequência da atuação dos órgãos da Administração da Justiça Penal e da resposta desigual que estes dão às vítimas segundo a procedência social e demais circunstâncias (HASSEMER; CONDE, 2011, p. 132).

Configurado esse novo contexto foi, a partir de então, que vários países, como Estados Unidos, Canadá e Austrália, passaram a legislar no sentido de acolher as vítimas durante o trâmite do processo penal, permitindo o relato emocional daquelas e dos seus familiares durante os julgamentos. Também inúmeros países, além dos citados, tais como Alemanha, Espanha, Nova Zelândia, Suíça, Holanda, França, Taiwan, Coréia do Sul, Colômbia, etc. criaram organizações, com apoio estatal, de proteção às vítimas. Para tanto, a principal diretriz veio da Assembléia Geral das Nações Unidas ${ }^{21}$, por meio da adoção, em 1985, da Declaração sobre os Princípios Básicos de Justiça Restaurativa para as Vítimas de Crimes e Abuso de Poder. Tal documento previa o direito das vítimas ao acesso à justiça, bem como a um tratamento justo, com compaixão e respeito e à sua dignidade, além de medidas necessárias para minimizar seu sofrimento e auxiliá-las na superação do trauma. Também dentro dessas diretrizes, abordava-se o direito à prestação de assistência material, médica, psicológica e social, através de instituições estatais ou organizações sociais, e o direito à compensação financeira pelos danos sofridos, que deveria ser assegurado pelo Estado, quando o ofensor não possuísse recursos para satisfazê-la. Ainda, havia menção para que os governos revisassem suas práticas,

\footnotetext{
${ }^{20}$ Um ponto de concentração dos estudos vitimológicos foi a vitimização secundária ou revitimização, isto é, o próprio efeito vitimizador que os órgãos encarregados da administração da justiça exercem quando, em suas investigações e atuações policiais ou processuais, expõem a vítima a novos danos ou incômodos, algumas vezes desnecessários, mas outras inevitáveis, para a investigação do delito. (HASSEMER; CONDE, 2011, p. 132)

${ }^{21}$ As Nações Unidas têm se preocupado com a questão das vítimas, tendo aprovado, com o voto do Brasil, a Declaração dos Direitos das Vítimas de Crimes e Abuso de Poder, em Assembléia Geral, no Congresso de Prevenção de Crime e Tratamento de Delinquente em Milão, na Itália, em 1985, ratificado em 1986 (KOSOVSKI, 2008, p. 150)
} 
regulações e leis com o objetivo de considerar a reparação realizada pelos ofensores, ou terceiros por estes responsáveis, quando do sentenciamento criminal; além disso, recomendou-se a adoção do uso de mecanismos informais de resolução de disputas, como mediação, arbitragem, justiça comunitária e práticas indígenas, quando se mostrarem apropriadas para facilitar a conciliação e a reparação das vítimas (ZAGALLO, 2010, p.17).

Neste ponto, quanto à recomendação de práticas mediadoras de justiça comunitária, além da maior atenção voltada às vítimas defendida pela Vitimologia, é que se pode relacionar o movimento de vitimização e as práticas restaurativas. No entanto, como bem observado por Mylène Jaccoud (2005, p.165):

O movimento vitimista inspirou a formalização dos princípios da justiça restaurativa, mas não endossou seus princípios nem participou diretamente do seu advento. É necessário, então, manter a prudência na análise das relações que o movimento vitimista mantém com a justiça restaurativa.

Tal prudência é necessária por que a maioria das organizações que foram criadas voltadas para a proteção às vítimas manifestou-se pela vontade de responsabilização, que não raro se confundia com o desejo de vingança, ensejando, assim, uma atuação com um maior incremento punitivo e revogação de direitos e garantias do acusados (ZAGALLO, 2010, p.20), o que vai de encontro aos objetivos restaurativos. Além disso, como se verá adiante, "a justiça restaurativa não é um movimento restrito às vítimas, visto que se preocupa com estas, mas também com o ofensor e a comunidade envolvida no conflito" (PALLAMOLLA, 2009, p.53)

Enfim, em linhas gerais, a Vitimologia teve como objetivo o debate da importância da vítima no sistema penal, quais são seus direitos, necessidades e expectativas, assim como, através da sua inclusão, propiciar um processo mais justo às partes:

[..] a abordagem vitimológica mostrou-se uma esperança, não de resolver o problema da criminalidade, mas de reduzi-lo e dar um tratamento mais humanitário e justo aos segmentos menos 
favorecidos da sociedade, auscultando-os, dando-lhes voz, incluindo-os como vítimas mais vulneráveis nas decisões sobre o seu destino, com o objetivo máximo de encontrar respostas positivas e benefícios para as partes envolvidas e, assim, aproximar-se da Justiça. O que também é o escopo dos Direitos Humanos e do Restaurativismo (KOSOVSKI, 2008, p.150-151).

Então, mesmo diante dos desencontros apontados, foi da Vitimologia, através do incentivo aos procedimentos de mediação, conciliação e reparação, estes destinados a aumentar a participação das vítimas no sistema penal, o grande mérito de dar notoriedade à importância da vítima na solução dos conflitos penais, já que:

O direito penal esqueceu da vítima ao tratar apenas da 'proteção de bens jurídicos', desde o viés do castigo àquele que cometeu um delito, e negligenciou o dano causado à vítima e a necessidade de reparação. Além do direito penal, também o processo penal esqueceu da vítima ao deixá-la à margem do processo e sem proteger seus direitos. Até mesmo a Criminologia esqueceu dela, pois tratou apenas do delinquente, num primeiro momento (Criminologia Positivista), para depois passar a entender o delito como um fenômeno relacional sem, entretanto, analisar a vítima da relação, restringindo-se, apenas, à análise dos processos de criminalização. (PALLAMOLLA, 2009, p.46)

Ficam aqui, como ponto conclusivo, as relevantes observações de Winfried Hassemer e Muñoz Conde (2011, p. 162), que, inclusive são oportunas para guiarem as práticas restaurativas:

Levar em consideração os interesses da vítima é hoje um efeito benéfico das correntes vitimológicas e uma exigência iniludível de respeito a seus direitos. Mas isso não deve redundar em uma lesão ou restrição de direitos fundamentais do imputado no processo penal, nem conduzir a uma política criminal puramente repressiva que infrinja princípios elementares da legalidade e intervenção mínima do Direito Penal. Tampouco se deve fomentar uma atitude vingativa ou justiceira dos direitos da vítima que as converta em algoz de seus antigos vitimários, desencadeando uma dialética de ação-reação que conduza mais a uma política de enfretamento que de apaziguamento entre os protagonistas do conflito penal. 


\subsection{O SISTEMA PENAL BRASILEIRO:}

\subsection{A CRISE DOS SISTEMAS PENAIS:}

Como visto no capítulo anterior, a Criminologia Positivista, ao considerar o crime como realidade ontológica e ao mistificar os mecanismos de seleção e estigmatização, contribuiu para a produção e reprodução da imagem estereotipada e preconceituosa da criminalidade e do criminoso vinculada aos baixos estratos sociais - que condiciona, por sua vez, a seletividade do sistema penal - num círculo de representações extraordinariamente fechado que goza de uma secular vigência no senso comum em geral e nos operadores do sistema penal (ANDRADE, 1996, p.286).

Por outro lado, com o advento dos estudos da Criminologia Crítica, refletiu-se e se observou que o discurso jurídico-penal está repleto de funções e promessas não cumpridas, tal como a ressocialização e prevenção da criminalidade. Ressalte-se que essa mudança paradigmática deu-se apenas no plano epistemológico da Criminologia, sem que essas constatações tenham significado mudanças substanciais na realidade dos sistemas de justiças penais dos Estados.

É na América Latina, como observa Zaffaroni (2001, p.35), que o aparecimento da Criminologia da reação social manifestou, com maior evidência, a falsidade do discurso jurídico-penal, revelando uma situação insustentável, em razão da gravidade dos resultados práticos da violência operacionalizada dos sistemas penais. Na verdade, os sistemas penais atuam de forma completamente diferente do que está previsto na sua programação normativa. Assim, nos sistemas penais latino-americanos, a verificação desta contradição entre discurso e realidade requer apenas uma observação superficial tal discurso se desarma ao mais leve toque com a realidade, visto que a dor e a morte que estes sistemas semeiam estão tão perdidas que o discurso jurídico-penal, diante das suas ficções gastas, não pode ocultar seu desbaratamento (ZAFFARONI, 2001, p.12-13). 
Eis que, segundo Zaffaroni (2001, p.15), está caracterizada a crise ${ }^{22}$ dos sistemas penais, principalmente, os latino-americanos, pois:

Hoje, temos a consciência de que a realidade operacional de nossos sistemas penais jamais poderá adequar-se à planificação do discurso jurídico-penal, e de que todos os sistemas penais apresentam características estruturais próprias de seu exercício de poder que cancelam o discurso jurídico-penal e que, por constituírem marcas de sua essência, não podem ser eliminadas, sem a supressão dos próprios sistemas penais. A seletividade, a reprodução da violência, a criação de condições para maiores condutas lesivas, a corrupção institucionalizada, a concentração de poder, a verticalização social e a destruição das relações horizontais ou comunitárias não são características conjunturais, mas estruturais do exercício de poder de todos os sistemas penais. (grifo nosso)

Diante de tal crise - há muito observada-, a partir da segunda metade do século XX surgiram, em âmbito mundial, instrumentos e declarações, principalmente das Nações Unidas, visando a redução do uso da pena de prisão e da justiça penal. Assim, muitos países incorporam mecanismos em suas legislações pátrias no intuito de desviar o ingresso de casos à justiça criminal e normas que objetivaram a aplicação de sanções penais distintas das penas privativas de liberdade ${ }^{23}$ (ILANUD, 2008, p.46-47).

No entanto, a população prisional vem crescendo e, na década que se iniciou no ano 2000, presenciamos taxas de pessoas presas possivelmente as mais altas das quais se têm registro na história da humanidade. Além disso, posteriormente, pesquisas criminológicas verificaram algo paradoxal: em vez de reduzir o uso da prisão, a utilização

\footnotetext{
${ }^{22}$ Zaffaroni utiliza o termo "crise" como uma brusca aceleração do descrédito do discurso jurídico-penal, como o momento em que a sua falsidade alcança tal magnitude de evidência, que este desaba, desconcertando o penalismo da região. Esclarece o autor que o discurso jurídico falso não é nem um produto de má-fé nem de simples conveniência, nem o resultado da elaboração calculada de alguns gênios malignos, mas é sustentado, em boa parte, pela incapacidade de ser substituído por outro discurso em razão da necessidade de se defenderem os direitos de algumas pessoas. Assim sendo, diante do reconhecimento da falsidade de seu discurso jurídico, o penalismo latino-americano estaria privado do único instrumento precário, mas instrumento- disponível para a defesa dos direitos humanos de alguns segmentos sociais (2001, p.14-16).

${ }^{23}$ No Brasil, tem-se como exemplo a Lei dos Juizados Especiais Criminais n ${ }^{\circ} 9.0099 / 95$, bem como outras penas alternativas incluídas na legislação.
} 
de penas não privativas de liberdade estaria gerando a chamada ampliação da rede de controle social ou de controle penal:

O efeito que as alternativas estariam causando seria a continuação das prisões de pessoas por condutas pelas quais antes se punia com a pena de prisão, mas, além disso, de outras pessoas que ante não teriam recebido prisão, sequer sanção alguma por suas condutas. Os juízes, ao terem também à sua disposição a aplicação desse outro tipo de resposta, optam agora por sanções "alternativas", com as quais não se reduz o número de pessoas presas, pelo contrário, captura-se, sob diversas formas de controle penal, um maior número de pessoas. (ILANUD, 2008, p.47)

Ainda, segundo Howard Zehr (2008, p.168), essa percepção de disfunção e crise do paradigma retributivo deve-se ao fato de que:

Nós vemos o crime através da lente retributiva. $\mathrm{O}$ processo penal, valendo-se desta lente, não consegue atender a muitas das necessidades da vítima e do ofensor. O processo negligencia as vítimas enquanto fracassa no intento declarado de responsabilizar os ofensores e coibir o crime. Tal incapacidade nos trouxe até a sensação de crise generalizada que vivemos hoje.

Dessa forma, todas essas medidas serviram apenas para realçar o caráter repressivo dos sistemas penais, sem, contudo, resolver o problema da crise da justiça criminal. Crise que cuja tendência é acentuar-se, pois, nos moldes atuais, os sistemas punitivos penais produzem mais problemas do que os resolvem porque não soluciona conflitos, mas tão somente os reprime.

Em suma, pode-se dizer que o panorama político-institucional que desencadeou a crise do direito e sistema penal moderno foi caracterizado pelos déficits do modelo tradicional de justiça, da legitimidade de uma ordem baseada num discurso esvaziado, de comunicação entre o sistema de justiça e as comunidades e o de participação popular na administração da justiça (SICA, 2006, p. 455). Portanto, tal colapso dos sistemas de justiça criminal e de regulação social deve-se, então, ao fato de que as normas do direito penal vêm gradativamente perdendo a capacidade de ordenar, moldar e conformar a sociedade, bem como seus mecanismos processuais também já não conseguem exercer de 
maneira eficaz seu papel de absorver tensões, dirimir conflitos, administrar disputas e neutralizar a violência (FARIA apud SICA, 2006, p. 455).

Enfim, incontáveis estudos, sob ângulos diversos (antropologia, criminologia, psicologia, sociologia e direito), atestaram, à exaustão, que os atuais modelos de justiça penal fracassaram nas suas missões, pois vêm contribuindo mais para a reprodução da violência do que para a sua contenção (SICA, 2008, p. 162).

É, então, nesse contexto de crise geral de ineficácia dos modelos punitivos que se situa o sistema penal brasileiro.

\subsection{O SISTEMA PENAL BRASILEIRO}

A realidade operada pelo sistema penal brasileiro coaduna-se com os fenômenos observados pela Criminologia da reação social. Assim, nas palavras de Nilo Batista: "seletividade, repressividade e estigmatização são algumas características centrais de sistemas penais como o brasileiro" (2001, p. 26). Continua o autor:

Assim, o sistema penal é apresentado como igualitário, atingindo igualmente as pessoas em função de suas condutas, quando na verdade seu funcionamento é seletivo, atingindo apenas determinadas pessoas, integrantes de determinados grupos sociais, a pretexto de suas condutas. As exceções, além de confirmarem a regra, são aparatosamente usadas para a reafirmação do caráter igualitário. O sistema penal é também apresentado como justo, na medida em que buscaria prevenir o delito, restringindo sua intervenção aos limites da necessidade (..), quando de fato seu desempenho é repressivo, seja pela frustração de suas linhas preventivas, seja pela incapacidade de regular a intensidade das respostas penais, legais ou ilegais. Por fim, o sistema penal se apresenta comprometido com o princípio da dignidade da pessoa humana (...), quando na verdade é estigmatizante, promovendo uma degradação na figura social da sua clientela. (BATISTA, 2001, p.26) 
Assim, nosso sistema de justiça penal - o qual elegeu a prisão como principal meio de resposta ao delito, diante de uma atuação seletiva, repressiva e estigmatizante, mostra-se ilegítimo. Ainda, revela que cumpre, na verdade, uma função que não assume, ao invés da função que declara (prevenção e ressocialização), que é a exclusão e marginalização das pessoas provenientes dos estratos sociais mais vulneráveis.

Utilizando-se das palavras de Marcos Rolim, pode-se dizer que o sistema penal brasileiro encontra-se falido, pois sua estrutura não previne, não ressocializa, bem como não funciona para a responsabilização de infratores, não produz justiça e tampouco constitui um verdadeiro sistema (ROLIM apud PALAMOLLA, 2009, p. 29). Ainda, segundo este autor:

A justiça criminal não funciona. Não porque seja lenta ou - em
sua "opção preferencial pelos pobres"- seletiva. Mesmo quando
é rápida e mais "abrangente", ela não produz "justiça", porque
sua medida é o mal que oferece àqueles que praticaram o mal.
Esse resultado não altera a vida das vítimas. O Estado as
representa porque o paradigma moderno nos diz que o crime é
um ato contra a sociedade. Por isso, o centro das atenções é o
réu, a quem é facultativo mentir em sua defesa. A vítima não
será, de fato, conhecida e o agressor jamais será confrontado
com as consequências de sua ação. (ROLIM apud
PALAMOLLA, 2008, p. 2)

Percebe-se, então, que o sistema penal brasileiro tem demasiadamente se afastado do ideal de justiça e harmonia social, o qual deveria permear toda a lógica de funcionamento do direito penal. Dessa forma, tem prevalecido a violência exagerada do modelo retributivo na nossa sociedade, que, como já dito, não compõe os conflitos. Neste ponto, oportuno citar, como exemplo, o próprio reconhecimento de magistrados, através da Associação Brasileira dos Juízes para a Democracia (apud PENIDO, 2006, p.568), sobre algumas dessas questões:

O grupo fundador partiu da constatação de que o Judiciário, como os demais poderes do Estado, não tem cumprido satisfatoriamente seu papel. Faltam-lhe eficiência e visão crítica para a justa solução dos conflitos. Os juízes, transformados em meros técnicos pela dogmática do positivismo jurídico e por uma cruel deontologia da magistratura cumprem, no cotidiano, o 
perverso papel de mero reprodutor das injustiças do sistema. Aplaudidos quando atribuem ao legislador a responsabilidade por eventual decisão injusta, são mantidos num universo de conflitos idealizados, afastados sem serem resolvidos.

Em suma, pontua-se que é nessa conjuntura de crises e déficits que as redes de justiça restaurativa surgem para, então, reconstruir os sistemas de controle social, sob uma perspectiva tripla: (i) acompanhar as transformações mais recentes no direito em geral, (ii) conter a expansão do direito penal na sua vertente mais repressiva (SICA, 2006, p. 455), (ii) bem como, ao considerar o crime como um conceito complexo, propor a real resolução dos conflitos.

Enfim, como consequência dessa justiça penal seletiva e repressiva, é que a realidade penitenciária brasileira se apresenta como muito grave, com multiplicidade de delitos e violações flagrantes e contínuas dos direitos humanos que têm lugar no seio do sistema penal brasileiro.

\subsection{A REALIDADE PRISIONAL BRASILEIRA:}

A realidade penitenciária pode-se dizer que constitui o maior exemplo, dentro de um país, pelo qual se pode verificar a discrepância entre as normas estabelecidas na legislação e a realidade apresentada tal como ela é. Oportuno lembrar, frase célebre do ex-presidente da África do Sul, Nelson Mandela, que esteve preso durante vinte e cinco anos. Disse ele: "ninguém conhece verdadeiramente uma nação até que tenha estado dentro dos porões de suas prisões".

As prisões ${ }^{24}$ são pequenas unidades sociais que refletem e reproduzem, em sua pequena dimensão, o lado bom e o lado ruim das sociedades que construímos. Em

\footnotetext{
24 Baratta (2002, p.166-167) explica que o surgimento da prisão está relacionado com o do capitalismo. Assim, nas origens, o sistema carcerário possuía como fim precípuo a disciplina de certos grupos da população para o trabalho nas fábricas. No entanto, o autor adverte que, mesmo diante do nexo histórico
} 
sociedades com grande desequilíbrio e pouca justiça social, dificilmente poderíamos ter prisões sem violência e boa justiça penal (ILANUD, 1998, p.46).

Segundo o Instituto Latino-Americano das Nações Unidas para a Prevenção do Delito e Tratamento do Delinquente/ ILANUD, o Brasil apresenta uma superpopulação carcerária ou aglomeração crítica. Essa é a situação em que a densidade penitenciária (relação entre o número de pessoas alojadas e o número de cargos disponíveis multiplicada por 100) é maior que 120 ou mais. O índice médio brasileiro, durante o período de 2005 a 2007, foi de 173. Ainda, segundo o Instituto, no período 1992 a 2008 , o Brasil foi, dentre os países latino-americanos, o que triplicou a taxa de pessoas presas por 100 mil habitantes. Ressalte-se que, nestes dados, nem foram considerados os presos alojados nas delegacias (ILANUD, 2008, p.52-56).

A partir dos dados referentes ao ano de 2007 da Comissão Parlamentar de Inquérito do Sistema Carcerário, a CPI Carcerária, criada para investigar a realidade prisional brasileira, o sistema prisional brasileiro é o quarto do mundo em número de pessoas presas (422.590), ficando atrás apenas dos Estados Unidos (2,2 milhões), China (1,5 milhão) e Rússia (870 mil). No entanto, em relação à capacidade de ocupação, verifica-se que o número de vagas do sistema penitenciário brasileiro totaliza 275.194 vagas. Assim, há um excedente de 53,56\% do que o sistema é capaz de sustentar (RELATÓRIO FINAL,CPI, 2008, p. 55).

Ainda, utilizando os dados mais recentes colhidos pelo Infopen $^{25}$, tem-se que, até dezembro de 2010, a população carcerária brasileira atingiu o número de 496.251 pessoas presas em presídios estaduais e delegacias. Ainda, um total de 12.762 presos federais que, somados aos presos estaduais, ultrapassa o número de meio milhão de presos (509.013). Para os presos estaduais correspondem 298.275 vagas do sistema penitenciário. Percebese que a configuração, assim como atestado pelo ILANUD desde 2002, da situação de

entre cárcere e fábrica, este elemento, numa fase histórica mais avançada, não é mais suficiente para ilustrar a relação atual entre a prisão e a sociedade, mas permanece, em todo caso, como matriz histórica.

${ }_{25}$ Infopen é o veículo utilizado pelo Ministério da Justiça, através do Departamento Penitenciário Nacional/DEPEN, para gerar informações penitenciárias atualizadas e que são disponibilizadas ao público no endereço eletrônico http://portal.mj.gov.br. 
superlotação carcerária é uma constante, e que tem aumentado cada vez mais, na realidade prisional brasileira.

A superpopulação carcerária é definida como um tratamento cruel, inumano e degradante pelas Nações Unidas. A superlotação além de ser um grave mal por si só, incide negativamente sobre todas as funções essenciais dos sistemas penitenciários ${ }^{26}$.

A partir dos dados do Infopen, até dezembro de 2009, o perfil dos encarcerados brasileiros, de um total de 473.626 presos, apresenta-se da seguinte forma: $77 \%$ possuem idade de até 34 anos (desta porcentagem, 32\% são de 18 a 24 anos) e 368.297 presos não chegaram a fazer um curso superior (destes, 172.926 nem completaram o ensino fundamental). Ainda, quanto à tipificação penal que a população masculina está sendo acusada ou já foi condenada: $29 \%$ por roubo; $20 \%$ por tráfico de entorpecentes; $16 \%$ por furto; $12 \%$ por homicídio; $6 \%$ relativo ao Estatuto do Desarmamento; $5 \%$ por crimes contra os costumes; $3 \%$ por receptação; $3 \%$ por latrocínio; $1 \%$ por estelionato e $5 \%$ por outros. Ressalta-se que só os crimes contra o patrimônio - roubos, furtos, estelionato e receptação- atingem $49 \%$, praticamente a metade dos tipos penais que resultam em pena de prisão.

Esses dados, indubitavelmente, confirmam o que já se disse até aqui: o sistema penal é seletivo, pois encarcera os desprovidos, aqueles que tiveram deficiências escolar e familiar, que não tiveram acesso à rede educacional. Aqui, oportuno o alerta de Vera Andrade: "a clientela do sistema penal é constituída de pobres não porque tenham uma maior tendência para delinquir, mas precisamente porque tem maiores chances de serem criminalizados e etiquetados como criminosos" (ANDRADE, 1996, p.283). Ainda, a CPI Carcerária constatou:

\footnotetext{
26 “A superlotação é talvez a mãe de todos os demais problemas do sistema carcerário. Celas superlotadas ocasionam insalubridade, doenças, motins, rebeliões, mortes, degradação da pessoa humana. A CPI encontrou homens amontoados como lixo humano em celas cheias, se revezando para dormir, ou dormindo em cima do vaso sanitário. Em outros estabelecimentos, homens seminus gemendo diante da cela entupida com temperaturas de até 50 graus. Assim vivem os presos no Brasil. Assim são os estabelecimentos penais brasileiros na sua grande maioria. Assim é que as autoridades brasileiras cuidam dos seus presos pobres. $\mathrm{E}$ é assim que as autoridades colocam todo santo dia, feras humanas jogadas na rua para conviver com a sociedade". (RELATÓRIO FINAL, CPI, 2008, p.220)
} 
A CPI observou a total ausência nas cadeias e presídios brasileiros de gente de posses, embora sejam frequentes as denúncias publicadas pela mídia, do envolvimento de pessoas das classes média e alta em crimes de homicídio, corrupção, fraudes, acidentes de trânsito e outros classificados como delitos do "colarinho branco". São rotineiras e em elevado número as prisões de envolvidos com estes tipos de crimes, mas a permanência dos mesmos atrás das grades é uma raridade. (...) Do outro lado da moeda, a CPI encontrou dezenas de presos encarcerados, apodrecendo em estabelecimentos desumanos e violentos por crimes simples, como furto de latas de leite, de peças de roupas, dívidas ou ameaças. (RELATÓRIO FINAL,CPI, 2008, p. 32-34) (grifo nosso)

No que tange aos tipos penais que levam à prisão, observou-se que os furtos e roubos são os responsáveis pela superlotação carcerária, pois ambos correspondem a 45\% da população presa. Assim, vê-se que a pena privativa de liberdade destina-se aos autores de crimes contra a propriedade, delitos nem sempre relevantes para a comunidade como um todo, mascarando, desse modo, os fatos criminosos realmente relevantes e fazendo com que a comunidade não volte sua atenção para aquilo que é mais importante (SHECAIRA, 2011, p. 376)

Neste ponto, preciosa a lição, tão presente na nossa realidade, de Baratta (2002, p.176 e p.198):

O sistema de valores que neles (direito e sistema penal) se exprimem reflete, predominantemente, o universo próprio de uma cultura burguesa individualista, dando a máxima ênfase à proteção do patrimônio privado e orientando-se, predominantemente para atingir as formas de desvios típicas dos grupos socialmente mais débeis e marginalizados. Basta pensar na enorme incidência de delitos contra o patrimônio na massa da criminalidade, tal como resulta a estatística judiciária (...) É difícil, como se sabe, que se realize um furto não "agravado" (...) As malhas dos tipos são, em geral, mais sutis no caso dos delitos próprios das classes sociais mais baixas do que no caso dos crimes de "colarinho branco" (...)

Estes delitos (contra a propriedade) constituem reações individuais e não políticas às contradições típicas do sistema de distribuição da riqueza e das gratificações sociais próprias da sociedade capitalista: é natural que as classes mais desfavorecidas deste sistema de distribuição estejam mais particularmente expostas a esta forma de desvio. 
Portanto, estes dados não significam, de modo algum, que o desvio criminal se concentre, efetivamente, na classe pobre e nos delitos contra o patrimônio, mas, pelo contrário, o comportamento criminoso se distribui por todos os grupos sociais. O que ocorre é que as classes dominantes, que praticam crimes, muitas vezes, de maior danosidade social, ficam imunes aos efeitos e não são perseguidas como a massa carente o é. Como atestou a CPI carcerária: o prejuízo para os governos Federal, Estaduais e Municipais com a ação de "ricos" e "influentes" que cometeram crimes contra o sistema financeiro e meio-ambiente é estimado em 18 bilhões de reais, segundo cálculos da própria Polícia Federal, Receita Federal, INSS, IBAMA e a Procuradoria Geral da República (RELATÓRIO FINAL, CPI, p.33).

A criminalidade está em todos os estratos sociais, mas acontece que não se pune as condutas típicas, mas sim certas e determinadas pessoas. Neste ponto, Zaffaroni explica que, na verdade, nem seria desejável que todas as condutas fossem criminalizadas, pois "se todos os furtos, todos os adultérios, todos os abortos, todas as defraudações, todas as falsidades, todos os subornos, todas as lesões, todas as ameaças, etc. fossem criminalizados, praticamente não haveria habitante que não fosse, por diversas vezes, criminalizado" (2001, p.26). Assim, se a capacidade operativa dos órgãos penais fosse suficiente, ou seja, "se o sistema penal tivesse realmente o poder criminalizante programado, provocaria uma catástrofe social”. Enfim, como não quer e não pode punir a todos, o sistema penal exerce seu poder com altíssimo grau de arbitrariedade seletiva dirigida, naturalmente, aos setores vulneráveis da sociedade (2001, p. 27).

Em relação aos números de prisões provisórias, segundo dados do Infopen relativos ao ano de 2010, de um total de 496.251 presos, 164.683 são presos provisórios. Assim, tem-se que um terço (1/3) da população carcerária está presa provisoriamente. Juntando-se a isso, apesar de ser de conhecimento notório da população e dos operadores do direito, a constatação, in loco, da CPI de que há milhares de presos provisórios que aguardam, há anos, sem qualquer perspectiva, um julgamento justo (RELATÓRIO 
FINAL,CPI, 2008, p. 34). Isso representa uma violação não apenas estrutural da legalidade processual, mas da própria legalidade penal, pois uma duração extraordinária dos processos penais provoca uma distorção cronológica que tem como resultado a conversão do auto de prisão em flagrante ou do despacho de prisão preventiva em autêntica sentença (ZAFFARONI, 2001, p.27).

No que tange à questão da reincidência, a CPI constatou que a taxa de reincidência dos condenados à pena privativa de liberdade oscila entre $70 \%$ e $85 \%$, enquanto o índice cai para $2 \%$ a $12 \%$ quando da aplicação das penas alternativas (RELATÓRIO FINAL, CPI, 2008, p.461).

Neste ponto, resta novamente claro a ineficácia da pena de prisão quanto às funções da prevenção especial e ressocialização do encarcerado. Isso porque:

Os institutos de detenção produzem efeitos contrários à
reeducação e à reinserçâo do condenado, e favoráveis à sua
estável inserção na população criminosa. O cárcere é contrário a
todo moderno ideal educativo, porque este promove a
individualidade, o auto-respeito do indivíduo, alimentando pelo
respeito que o educador tem dele. As cerimônias de
degradação ${ }^{27}$, no início da detenção, com os quais o encarcerado
é despojado até dos símbolos exteriores da sua própria
autonomia (vestuários e objetos pessoais), são o oposto de tudo
isso. A educação promove o sentimento de liberdade e de
espontaneidade do indivíduo: a vida no cárcere, como universo
disciplinar, tem um caráter repressivo e uniformizante
(BARATTA, 2002, p. 183-184).

Para a literatura criminológica, o processo de socialização negativo ao qual o encarcerado é submetido possui duas facetas: primeiro, há um processo de desculturação, ou seja, de desadaptação às condições necessárias para a vida em liberdade, de distanciamento progressivo dos valores e dos modelos de comportamento próprios da sociedade externa. A segunda etapa é a de aculturação ou prisionalização, que se trata da assunção dos modelos de comportamento e dos valores característicos da subcultura

\footnotetext{
27 "Além da deformação pessoal que decorre do fato de a pessoa perder seu conjunto de identidade (nome, roupa, maneira de cortar o cabelo, postura que deverá ser 'respeitosa'), perderá um sentido de segurança pessoal que constituirá um fundamento para as suas angústias e seu desfiguramento pessoal. Viverá um ritual diário de medo, pois não terá garantida sua integridade física" (SHECAIRA, 2011, p.317).
} 
carcerária. Quanto à prisionalização, destacam-se dois aspectos característicos: a educação para ser criminoso e a educação para ser bom preso. Esses processos negativos praticamente nenhuma técnica psicoterapêutica e pedagógica consegue equilibrar (BARATTA, 2002, p. 184-185).

Além desse processo negativo de socialização, o detido é submetido a um complexo processo de estigmatização, já explicado no capítulo anterior, ao entrar na prisão; porém, não recebe do sistema penal um processo equivalente de desestigmatização (SHECAIRA, 2011, p.376). Por isso, o rótulo criminal dado a um indivíduo e cristalizado em folhas de antecedentes, certidões criminais, ou surgido mediante a divulgação sensacionalista na mídia produz a assimilação de suas características pelas pessoas rotuladas, a geração de expectativas sociais de condutas correspondentes ao seu significado, a perpetuação do comportamento criminoso e a aproximação recíproca de indivíduos também já estigmatizados (SHECAIRA, 2011, p.316).

Por fim, percebe-se, diante dos dados apresentados, a total falibilidade do sistema penal brasileiro nos moldes em que se apresenta. Some-se à seletividade e à estigmatização os horrores vividos ${ }^{28}$ e ilegalidades perpetradas contra os encarcerados brasileiros. A realidade prisional brasileira, como não poderia ser diferente, representa a relação geral entre cárcere e sociedade que, antes de tudo, é uma relação entre quem exclui (sociedade) e quem é excluído (preso). Assim, toda técnica pedagógica de

\footnotetext{
${ }^{28}$ Segundo a CPI Carcerária, o sistema carcerário nacional é, seguramente, um campo de torturas psicológicas e físicas. A CPI constatou, na maioria dos presídios brasileiros, o desrespeito a integridade moral dos presos, diante da existência de celas superlotadas; a falta de espaço físico; a inexistência de água, luz, material higiênico, banho de sol; a constatação de lixo, esgotos, ratos, baratas e porcos misturados com os encarcerados; presos doentes sem atendimento médico e amontoados em celas imundas, dentre outras situações descritas nas diligências que foram fotografadas e filmadas (RELATÓRIO FINAL,CPI, 2008, p. 246). Massimo Pavarini, ao analisar a precária realidade prisional brasileira, diz que: "há uma regra econômica que diz que a prisão, em qualquer lugar do mundo, deve ter uma qualidade de sobrevivência inferior à pior qualidade de vida em liberdade. Como aqui há favelas, as prisões têm de ser piores do que as piores favelas. A prisão tem de oferecer uma diferenciação social entre o pobre bom e o pobre delinquente. O presídio ruim tem função simbólica" (Entrevista concedida à Folha de São Paulo. Disponível em http://profmatzenbacher.blogspot.com/2009/09/entrevista-prof-massimo-pavarini.html.).
} 
reinserção do detido choca contra a natureza mesma desta relação de exclusão. Não se pode, ao mesmo tempo, excluir e incluir (BARATTA, 2002, p.186). Ainda que fosse possível ressocializar alguém o retirando da sociedade, para tanto seria necessário um Estado que fornecesse as condições mínimas de dignidade aos encarcerados, o que infelizmente não se verifica no Brasil (SHECAIRA, 2011, p.319).

Perante todo o panorama exposto, deve-se repensar em que medida as tecnologias do castigo contribuíram para a situação insustentável do sistema carcerário brasileiro (FERREIRA, 2011, p.2). A construção de mais prisões e a aprovação de leis que prevêem penas detentivas ainda mais severas apenas representam o meio que as autoridades políticas, principalmente as que trabalham com o crime, encontram para que todos vejam que alguma "coisa está se fazendo a esse propósito", qualquer coisa, especialmente para que se possa reafirmar a segurança, a lei e a ordem (SHECAIRA, 2011, p. 377). No entanto, a solução não é bem por aí. Dada tal situação de insustentabilidade, é mais que necessário pensar em soluções para desafogar o sistema. É nesse sentido, dentre outro objetivos, que surge a Justiça Restaurativa, como nova forma de solução de conflitos mais humana e menos excludente.

Por fim, antes das considerações do próximo capítulo, cabe ressaltar o alerta de Leonardo Sica (2006, p.455) de que, quando se fala em introdução da Justiça Restaurativa, não se trata somente de escolha de novos métodos de resolução de conflitos ou de mecanismos para aliviar o Poder Judiciário ou o sistema penal, tampouco de debate de uma nova teoria penal. A ideia é a de elaboração de um novo modelo de justiça penal que influa e altere decisivamente a nossa maneira de pensar e agir em relação à questão criminal. 


\subsection{A TEORIA RESTAURATIVA:}

Parafraseando Howard $Z_{\text {ehr }}^{29}$, uma boa maneira de iniciar a exploração deste capítulo é tirando o conceito de crime do seu pedestal absoluto (2008, p. 170).

A justiça restaurativa ${ }^{30}$ propõe, então, a redefinição do conceito de crime que, para o modelo retributivo tradicional, é apenas a violação típica de uma norma penal. Para os teóricos restaurativos, o delito é muito mais que infração às regras estabelecidas, pois ele pode ser um causador de prejuízos e sofrimentos, um conflito que convém resolver ou um evento que não apenas afeta as relações entre as pessoas, mas que também envolve os familiares das vítimas e infratores, sua comunidade circunvizinha ou seus relacionamentos. Desse modo, segundo Mylène Jaccoud (2005, p. 169), “o crime não é mais concebido como uma violação contra o Estado ou como uma transgressão a uma norma jurídica, mas como um evento causador de prejuízos e consequências".

Howard Zehr (2008, p.170) afirma que o conceito de crime pode ser visto sob duas lentes diferentes. Sob a lente da justiça retributiva, "o crime é uma violação contra o Estado, definida pela desobediência à lei e pela culpa. A justiça determina a culpa e inflige dor no contexto de uma disputa entre ofensor e Estado, regida por regras sistemáticas". Por outro lado, a partir da lente restaurativa, "o crime é uma violação de pessoas e relacionamentos. Ele cria obrigações de corrigir erros. A justiça envolve a vítima, o ofensor e a comunidade na busca de soluções que promovam reparação, reconciliação e segurança".

Assim, sendo o delito entendido como uma ofensa ou uma lesão a outras pessoas e relacionamentos, a justiça deve atuar para restaurar a situação e não apenas para retribuir com mais violência. Para tal restauração, impõe-se a necessidade de uma reação

\footnotetext{
${ }^{29}$ Zehr é um dos grandes teóricos, ao lado de John Braithwaite, do movimento restaurativo. Em 1990, escreveu a obra Trocando as lentes, um livro decisivo na eclosão da justiça restaurativa como paradigma que marca uma ruptura com o modelo retributivo.

${ }^{30}$ Embora o termo justiça restaurativa seja dominante, alguns autores utilizam também justiça transformadora, transformativa, relacional, restaurativa comunal, recuperativa e participativa.
} 
diferenciada. Reação esta que deve estar preocupada com a determinação de uma resposta adequada ao comportamento delituoso, mas também com a reparação, material ou simbólica, dos danos causados (SICA, 2006, p. 459).

Percebe-se, então, que a lente retributiva desconsidera que por trás e após o cometimento de um delito podem existir vários conflitos interpessoais e, portanto, diante de tal desconsideração, o Estado torna a comunidade, a vítima e o infrator como algo abstrato e impessoal. O que importa reconhecer é que, no modelo punitivo, a ofensa é definida em termos técnico-jurídicos enquanto, no modelo restaurativo, ela passa a ser compreendida em seu contexto social, ético, econômico e político (ZEHR, 2008, p. 174).

Portanto, partir dessa reconstrução da noção de crime proposta pela justiça restaurativa é um aspecto imprescindível para compreendê-la.

\subsection{EVOLUÇÃO HISTÓRICA DA JUSTIÇA RESTAURATIVA}

Há uma dificuldade de se estabelecer qual foi exatamente o processo histórico que antecedeu e desencadeou as atuais concepções de justiça restaurativa. Isso porque, podese verificar, tanto no Oriente quanto no Ocidente, diferentes origens, dada a diversidade de contextos histórico-culturais, de práticas que apresentam um caráter restaurativo.

No entanto, diante de um esforço para verificar, no tempo, os primeiros sinais de práticas restaurativas no mundo, pode-se dizer que:

Os vestígios dessas práticas restaurativas, reintegradoras e negociáveis se encontram em muitos códigos decretados antes da primeira era cristã. Por exemplo, o código de Hammurabi (1700 a.C) e de Lipit-Ishtar (1875 a.C) prescreviam medidas de restituição para os crimes contra os bens. $\mathrm{O}$ código sumeriano (2050 a.C) e o de Eshunna (1700 a.C) previam a restituição nos casos de crimes de violência (Van Ness e Strong, 1997). Elas podem ser observadas também entre os povos colonizados da África, da Nova Zelândia, da Áustria, da América do Norte e do 
Sul, bem como entre as sociedades pré-estatais da Europa. (JACCOUD, 2005, p.164)

Estas formas de justiça negociada já expressas nos códigos ${ }^{31}$ citados deviam-se ao modelo de organização social dessas sociedades comunais - sociedades pré-estatais européias e as coletividades nativas - que privilegiavam os interesses coletivos ao invés dos individuais. Dessa forma, possuíam regulamentos sociais voltados para a manutenção e coesão do grupo e, em caso de transgressão de normas, buscava-se uma solução rápida capaz de restabelecer o equilíbrio rompido. Desse modo, mesmo não tendo excluído formas de punição como a vingança e a morte, as sociedades comunais tendiam a utilizar mecanismos capazes de conter toda a desestabilização do grupo social (JACCOUD, 2005, p.164).

Howard Zehr (2008, p. 94-102) explica que a vingança, quando ocorria, era apenas uma dentro de um conjunto muito mais amplo de opções, e, ainda, tinha uma aplicação limitada e seu papel e significado eram diferentes do que hoje imaginamos. Nessas comunidades, a maior parte dos crimes, era retratada essencialmente como um mal cometido contra uma pessoa ou como um conflito interpessoal. Assim, o que mais importava era o dano efetivamente causado do que a violação das leis e da ordem social abstrata. Por conseguinte, surgido o dano, nascia o dever de compensação material e, muitas vezes, moral. Esta compensação, mesmo em casos de delitos contra a pessoa, era feita por meio de um acordo realizado entre vítimas e ofensores, bem como parentes e comunidade desempenhavam papel vital na sua realização. A administração da justiça era, portanto, primariamente, um processo de mediação e negociação mais do que um processo de aplicação de regras e imposição de decisões, assumindo, daí, mais um caráter de justiça comunitária do que de justiça estatal. As cortes constituíam uma espécie de árbitro, pois se as partes chegassem a um acordo, era permitido que encerassem o

\footnotetext{
${ }^{31}$ Além dos códigos citados, também a literatura aponta o Pentateuco, em Israel, que previa restituição para os crimes contra a propriedade; a Lei das XII Tábuas (449 a.C), que ordenava que ladrões culpados deveriam pagar o dobro do valor das mercadorias roubadas; as Leis de Ethelbert de Kent, na Inglaterra, que previam detalhadas planilhas de restituição e o Direito Germânico, através de leis como as promulgadas pelo Rei Clóvis I, que exigia restituição tanto para ofensas violentas, quanto para as não-violentas (AMORIM, 2008, p. 63-64)
} 
processo a qualquer tempo. Enfim, o que o autor pretende demonstrar é que nossa visão moderna de justiça "mais racional e humana" considera, de forma negativa e simplista, a justiça pré-moderna como vingativa e bárbara. É certo que na justiça comunitária ocorriam penalidades muito atrozes; no entanto, ela valorizava muito a manutenção dos relacionamentos e a reconciliação, demonstrando que possuía talvez uma concepção de crime melhor do que a nossa concepção "racional".

Zehr (2008, p.103-105) relata, ainda, que este ideal de justiça restitutiva negociada, ao final da Idade Média, foi sendo substituído pelo ideal retributivo. No século XIX, com a pretensão dos Estados Modernos do monopólio do uso da violência, da produção normativa e da promoção da paz, ocorreu a "revolução jurídica" responsável pela ideia de sistema penal que temos hoje. O Estado substituiu os cidadãos, passando a ser o acusador e a vítima. Consequentemente, o papel e as pretensões das vítimas se perderam nesse processo histórico.

Enfim, importa perceber que, mesmo tendo-se afirmado que a justiça restaurativa teve como antecedentes teóricos a Criminologia e a Vitimologia, ambos frutos do século $\mathrm{XX}$, percebe-se que "as práticas restaurativas já se encontravam presentes nas tradições de povos do Oriente e Ocidente, nas quais princípios restaurativos teriam caracterizado, por séculos, os procedimentos de justiça comunitária ${ }^{32 "}$ (PALLAMOLLA, 2009, p.36).

De fato, somente na segunda metade do século XX, por influências das correntes até aqui desenvolvidas, é que a justiça restaurativa nasce com as feições e princípios que a construíram e continuam construindo até hoje.

O ressurgimento internacional do interesse sobre o movimento restaurativo deveu-se a uma reação à situação de ineficiência e altos custos, tanto financeiros como humanos, do sistema de justiça tradicional e ao fracasso deste sistema quanto à

\footnotetext{
${ }^{32}$ Considera-se que a construção do movimento restaurativo, em geral, também está ligada às tradições indígenas e religiosas de resolução de conflitos, pois estas tendem a enxergam o crime como dano às pessoas e à comunidade, bem como privilegiam o diálogo.
} 
responsabilização dos infratores e à atenção dada às necessidades e interesses das vítimas (MORRIS, 2005, p. 440-441).

Diretamente associada, em seu início, ao movimento de descriminalização, ela deu passagem ao desdobramento de numerosas experiências-piloto do sistema penal a partir da metade dos anos setenta (fase experimental), experiências que se institucionalizaram nos anos oitenta (fase de institucionalização) pela adoção de medidas específicas. A partir dos anos 1990, a justiça restaurativa conhece uma fase de expansão e se vê inserida em todas as etapas do processo penal (JACCOUD, 2005, p. 166).

Nessa mesma época, incentivadas pelos altos índices de encarceramento de jovens aborígenes e pela forma como estes eram tratados pelo sistema de justiça criminal, foram realizadas na Austrália, Nova Zelândia e Canadá conferências baseadas em princípios restaurativos, estas utilizadas como uma alternativa ao sistema criminal tradicional (VANFRAECHEM apud ZAGALLO, 2010, p.27).

Assim, a justiça restaurativa tornou-se o modelo dominante de justiça informal capaz de melhorar, ou mesmo reverter, a situação criada e mantida pelo sistema de justiça tradicional.

A partir de então, programas bem estabelecidos de justiça restaurativa podem ser encontrados em vários países, tais como o Canadá (mais de 400 programas), Nova Zelândia, Austrália, Estados Unidos (cerca de 770 programas), Argentina, Singapura, África do Sul e em vários países da Europa (cerca de 500 programas) (ROCHE apud ZAGALLO, 2010, p.27). Por outro lado, diante dessa mundial tendência restaurativa, os programas criados apresentavam muitas distinções entre si, o que poderia comprometer a qualidade dos projetos e a consecução dos princípios restaurativos. Assim, entre outros objetivos, em 2002, a Organização das Nações Unidas promulgou uma resolução dos Princípios Básicos sobre o uso de Programas de Justiça Restaurativa em Matéria Criminal no intuito de nortear os projetos de justiça restaurativa já criados ou que 
viessem a ser criados. Ainda, os Estados que aderiram ao paradigma restaurativo moveram-se no sentindo de aperfeiçoar, cada vez mais, suas práticas e legislações.

Nesse contexto, vale ressaltar que o Brasil, como se verá adiante, só passa a experimentar oficialmente o movimento restaurativo, apesar das experiências mundiais pioneiras datarem da década de 1970, no início deste século.

\subsection{ABORDAGEM CONCEITUAL}

Um marco simbólico atual de definição da justiça restaurativa foi o proposto pelo Conselho Econômico e Social das Nações Unidas, através da Resolução ${ }^{33}$ n $^{\circ}$ 2002/12. Segundo este documento, "programa de justiça restaurativa significa qualquer programa que utilize processos e voltados para resultados restaurativos."

Apesar de tautológica, esta definição revela a abertura conceitual da justiça restaurativa. Isso porque a justiça restaurativa não possui um conceito fechado, pois construir uma definição única limitaria suas potencialidades e inibiria a realização de vários procedimentos que possam alcançar resultados restaurativos. Assim, diante das diversas orientações teóricas e práticas que a justiça restaurativa pode propor, melhor seria compreendê-la como um modelo eclodido (JACCOUD, 2005, p. 163). Nas palavras de Raffaella Pallamolla (2008, p. 54) “a justiça possui um conceito não só aberto como, também, fluido, pois vem sendo modificado, assim como suas práticas, desde os primeiros estudos e experiências restaurativas.

No entanto, tal flexibilidade conceitual poderia pôr em risco a eficácia da justiça restaurativa na medida em que todo e qualquer procedimento pudesse ser encaixado como restaurativo. Daí, diante da possível avaliação negativa de vários modelos

\footnotetext{
${ }^{33}$ Essa Resolução internacional é um marco jurídico de referência da Justiça Restaurativa, tendo sido elaborada em face da discussão dos últimos anos sobre os temas de prevenção criminal, respeito às vítimas e necessidade de desenvolver instrumentos e princípios para o uso do modelo restaurativo.
} 
restaurativos, a literatura preocupa-se com a construção de conceitos, ainda que abertos, capazes de expressar os princípios básicos que norteiam a justiça restaurativa. Então, como padrões mínimos são essenciais, o desafio é, segundo John Braithwaite, “forjar padrões de justiça restaurativa de tramas abertas, que permitam muito espaço para as diferenças culturais (...)” (apud MARSHALL; BOYACK; BOWEN, 2005, p.269).

Nesse sentido, Marshall, de forma simplória e bastante significativa, define justiça restaurativa como um processo pelo qual todas as partes que têm interesse em determinada ofensa juntam-se para resolvê-la coletivamente e para tratar suas implicações futuras (LARRAURI, 2009, p. 171).

Mylène Jaccoud (2005, p. 179) conceitua como "uma abordagem que privilegia qualquer forma de ação objetivando a reparação das consequências vivenciadas após um delito ou um crime, a resolução de um conflito ou a reconciliação das partes unidas pelo conflito".

Paul Mccold e Ted Wachtel (2003, p.1-3) entendem a justiça restaurativa como uma nova maneira de abordar a justiça penal, que enfoca a reparação dos danos causados às pessoas e relacionamentos, ao invés de simplesmente punir os agressores; configurando-se, assim, como um processo colaborativo que envolve as principais partes afetadas pelo crime no intuito de determinar qual a melhor forma de reparar o dano causado pela transgressão.

Além dessas definições, John Braithwaite enxerga a justiça restaurativa como uma forma de lutar contra a injustiça e a estigmatização (PALLAMOLLA, 2008, p. 54).

Na literatura brasileira, Renato Sócrates (2005, p.20) explica:

Justiça restaurativa baseia-se num procedimento de consenso, em que a vítima e o infrator, e, quando apropriado, outras pessoas ou membros da comunidade afetados pelo crime, como sujeitos centrais, participam coletiva e ativamente na construção de soluções para a cura das feridas, dos traumas e perdas causados pelo crime. 
Ainda, Pedro Scuro Neto (2008, p.170) entende a justiça restaurativa como uma influência estabilizadora, um instrumento de reafirmação do papel do Estado na aplicação de justiça, com integral respeito à dignidade de todas as pessoas envolvidas e ao seu direito de terem reconhecidos seus valores e pontos de vista.

Enfim, diante dos vários conceitos expostos, importa perceber que essa nova forma de abordar a justiça compreende essencialmente os seguintes elementos: a participação das partes principais atingidas pelo crime como sujeitos centrais no processo; a oportunidade de diálogo; a ênfase na reparação dos danos, materiais e morais, sofridos e a restauração, na medida do possível, da dignidade e do bem-estar dos prejudicados pelo incidente.

Enfim, diante desta abordagem conceitual, as práticas restaurativas só poderão ser assim reconhecidas se expressarem os valores e virtudes humanas que são essenciais aos relacionamentos saudáveis, equitativos e justos (MARSHALL, et al, 2005, p.269). Por isso, para melhor compreender a justiça e processos restaurativos, já situados no plano teórico, torna-se necessário delimitar as fronteiras axiológicas, ou seja, os valores e princípios, e as implicações práticas deste modelo.

\subsection{VALORES RESTAURATIVOS E CONTORNOS PRÁTICOS:}

Inicialmente, cabe ressaltar que, na literatura acerca da justiça restaurativa, existem vários valores e princípios apontados como centrais ao modelo. No entanto, neste trabalho, abordar-se-ão somente aqueles sobre os quais existe um maior consenso.

Por opção metodológica, a caracterização dos valores restaurativos será feita a partir da delimitação de três categorias denominadas como: processo dialogado, reparação e restauração. 


\subsubsection{PROCESSO DIALOGADO}

A ideia de um processo dialogado denota a existência de diálogo entre as principais partes afetadas pelo delito que possibilite responder a três questionamentos: Qual é o dano? Que se deve fazer para repará-lo? Quem é o responsável por fazê-lo? (LARRAURI, 2009, p.171).

Para atingir o momento do diálogo entre as partes, estas devem consentir com a sua participação. Aqui, verifica-se o valor da voluntariedade ${ }^{34}$, pois ninguém deve ser coagido a participar ou a continuar no processo, ou, ainda, ser compelido a se comunicar contra a sua vontade. Segundo os teóricos restaurativos, a participação voluntária do ofensor no processo expressa a sua compreensão do dano cometido, bem como sua vontade de repará-lo, demonstrando, assim, a obediência às normas sociais e o reconhecimento dos direitos da vítima. A voluntariedade é, assim, valor necessário para a maximização do processo restaurativo. No entanto, apesar de voluntário, é importante que as partes sejam informadas e encorajadas a participaram do processo. Portanto, o processo dialogado é fundamental porque permite a participação, esta um valor democrático de que o sistema penal tradicional está enormemente necessitado.

Por partes interessadas entende-se o ofensor, a vítima e a comunidade, esta envolvendo principalmente aquelas pessoas que tenham vínculo de afeto ou atenção ou que possam oferecer assistência à vítima e ofensor ${ }^{35}$. Para o ofensor, a importância está na oportunidade de reparar o dano, pacificar os ânimos da vítima, demonstrar seu desejo

\footnotetext{
${ }^{34}$ A existência da voluntariedade é dominante entre os teóricos (minimalistas) do tema. No entanto, cabe ressaltar que há autores (maximalistas) que não consideram este valor como essencial. Lode Walgrave (2006, p.434), por exemplo, diz que, apesar de a participação voluntária aumentar a qualidade do processo, há momentos em que a coerção parece ser a única forma de fazer justiça, defendendo, assim, a possibilidade de imposição de sanções restaurativas. Isso porque, segundo o autor, a exigência de processos unicamente voluntários leva a confinar a aplicação da justiça restaurativa a pequenas causas. Nesse mesmo sentido são os posicionamentos de Mylène Jaccoud (2005, p.180).

35 Assim, por exemplo, podem participar do processo restaurativo: os familiares e amigos (também chamadas de vítimas secundárias) e a comunidade (professores, vizinhos, grupos de apoio, assistentes sociais, etc.).
} 
de estar inserido na comunidade, o que propicia que ele tenha consciência da ofensa realizada. Por outro lado, a vítima pode externar seus sentimentos de ira, medo, angústia, suas perdas e ponderações acerca da ofensa, o que contribui para superar o trauma causado pelo delito. Nesse contexto, Zehr e Toews (2006, p.426) explicam: “a superação do trauma requer que eles reconstruam o sentido de suas vidas. A oportunidade de contar e analisar a sua própria história, em suas próprias palavras, e talvez até ouvir as histórias dos outros participantes, é um elemento essencial nessa trajetória".

Em relação à comunidade, Larrauri (2009, p. 174) bem aborda a sua importância:

A defesa da ampliação de pessoas participantes obedece, geralmente, a diversos motivos. Por um lado, criam-se mais benefícios para a vítima e infrator. Destaca-se que se sentem mais apoiados pela presença das comunidades de cuidado community of care. Em segundo lugar, a presença da comunidade é defendida, por vezes, referindo-se que permitirá o controle informal a respeito do infrator, sendo de se esperar que este maior controle redunde em uma diminuição de futuros delitos. Finalmente, alude-se, também à possibilidade de a presença da comunidade, nas conferências da justiça restaurativa, revitalizar a comunidade.

Também, como partícipes do processo dialogado, encontra-se a figura dos facilitadores, cuja tarefa é facilitar a discussão e velar por determinadas regras de procedimento e natureza dos acordos. Os facilitadores devem ser imparciais, confiáveis e capacitados para utilizar as técnicas de mediação penal, e, ainda, as partes devem entender e concordar com o processo que eles propõem. Os mediadores devem corresponder às expectativas das partes criadas nos processos de pré-encontro restaurativo. Estes processos de pré-encontro são voltados para a preparação das partes para o encontro direto restaurativo.

Durante o encontro restaurativo, os facilitadores devem promover a inclusão e a colaboração de todas as partes envolvidas, bem como mostrar os mesmos interesses e compromisso em relação às vítimas e ofensores. Dessa maneira, eles devem encorajar a vítima e o ofensor a assumir papéis ativos para resolver o conflito, através da discussão e 
da negociação. Aos facilitadores fica reservado somente um instrumento de intervenção: a linguagem, o que os coloca no mesmo nível de poder das partes (SICA, 2006, p.459).

Ao assumirem papéis ativos no processo, as partes experimentam o valor do empoderamento, pois todo ser humano requer um grau de determinação e autonomia nas suas vidas. O crime rouba este poder das vítimas, já que o ofensor exerceu poder sobre elas sem consentimento. No entanto, o valor do empoderamento é devolvido à vítima na medida em que ela pode determinar quais são suas necessidades e como estas podem ser satisfeitas. Também, o processo dialogado dá poder aos ofensores de se responsabilizarem por suas ofensas, fazer o que for possível para remediar o dano que causaram e, ainda, iniciar um processo de reabilitação ou reintegração (MARSHALL, et al, 2005, p.273). Nesse contexto, é essencial que os facilitadores, durante o encontro restaurativo, esforcem-se para equilibrar os possíveis desníveis de poder entre as partes, promovendo, assim, o valor da não-dominação de uma sobre outra e o diálogo respeitoso entre ambas.

Em relação aos valores da não-dominação, empoderamento e escuta respeitosa, Braithwaite (PALLAMOLLA, 2009, p. 62-63) os considera como constraining values, ou seja, são valores obrigatórios do processo restaurativo para prevenir que este se torne opressivo. Assim, segundo este teórico, a não-dominação significa que a tentativa de dominar o outro deve ser contornada, cabendo, aos demais participantes identificarem a dominação e dar voz a quem está sendo dominado. Se esta tentativa falhar ou não ocorrer, o facilitador poderá intervir e dá voz à pessoa dominada. A não-dominação promoverá o empoderamento. Este valor significa também que as partes possuem poder de contar as suas histórias do seu modo. Como exemplo, se a vítima não aceitar as desculpas do ofensor, a conferência deve empoderá-la para que o faça. Por fim, quanto ao valor da escuta respeitosa, significa que escutar o outro respeitosamente é condição de participação, pois os cidadãos não podem desrespeitar, diminuir ou oprimir o outro.

O processo restaurativo também deve prezar pelo valor da informalidade e confidencialidade. Em relação ao primeiro, a ideia é que o processo restaurativo 
desvencilhe-se da estrutura extremamente formalista e burocrática dos modelos tradicionais, por isso, por exemplo, são realizados em ambientes acolhedores e sem a necessidade de participação do juiz e promotor. Também expressa a ideia da celeridade, pois sendo mais informal, o processo restaurativo tende a ser mais célere, resolvendo o conflito e restabelecendo laços em um menor espaço de tempo ${ }^{36}$. Quanto ao valor da confidencialidade, os participantes devem ser encorajados a manter a confidencialidade do que é dito no encontro restaurativo e não revelar esses fatos a pessoas que não tenham envolvimento pessoal no incidente. No entanto, esse valor não deve ser entendido como absoluto, pois podem existir, em alguns casos, fortes considerações legais, éticas ou culturais que o sobrepujem (MARSHALL, et al, 2005, p.269).

Ainda, no que diz respeito à confidencialidade, Van Ness explica que a justiça restaurativa não se baseia no caráter público das seções e que o caráter confidencial das discussões deve se manter também em relação ao sistema penal, o qual deve ser apenas informado do acordo adotado ou da falta deste, mas não do conteúdo das deliberações (LARRAURI, 2009, p. 179).

A esta altura, é importante também abordar resumidamente os diversos formatos e momentos nos quais podem ser realizados os processos dialogados. Em relação aos formatos, têm-se as conferências vítima-ofensor, conferências familiares e os círculos. As primeiras, nascidas na Europa ${ }^{37}$ e na América do Norte, são os processos em que envolve principalmente a vítima e o ofensor, auxiliados por um mediador, que visam reparar o dano causado. Nas conferências familiares, predominantes na Austrália e na Nova Zelândia, além da vítima, ofensor e facilitador, incluem-se os familiares e pessoas que são importantes para as partes. É um modelo que fortalece os laços familiares. Em relação aos círculos, surgidos no Canadá, estes podem ser de paz, de sentença ou de

\footnotetext{
${ }^{36}$ No entanto, a celeridade deve ser entendida com prudência, pois não é objetivo absoluto da justiça restaurativa ser mais célere, sob uma perspectiva utilitarista, e descuidar, assim, da qualidade do processo restaurativo. Na verdade, as sessões de pré-encontros ou os círculos com as partes podem se multiplicar e levar mais tempo, quando os facilitadores verificarem a necessidade.

${ }^{37} \mathrm{Na}$ Europa, os países da Áustria, Inglaterra, Finlândia e Noruega utilizam fortemente esse formato.
} 
sanção. Aqui, além das partes principais, há a participação de membros do sistema judicial $^{38}$ (juiz, promotor, advogados) (TELLO, 2008, p. 207).

No que tange aos momentos de aplicação, a literatura, em suma, aponta que o processo restaurativo pode ser aplicado antes ou depois da interposição da ação penal ou, ainda, após a sentença condenatória e durante a própria execução da pena de prisão.

Enfim, outro valor que merece ser destacado é a humildade. Este valor se expressa na aceitação das falibilidades e a vulnerabilidade comuns a todos os seres humanos. A humildade para reconhecer esta condição humana universal capacita as vítimas e infratores a descobrirem que eles podem ter mais em comum como seres humanos frágeis e imperfeitos do que o que os divide como vítima e ofensor (MARSHALL, et al, 2005, p.272). O processo dialogado permite que, na maioria das vezes, as partes se desapeguem dos estereótipos, estigmas e preconceitos.

\subsubsection{A REPARAÇÃO}

A reparação é fundamental à justiça restaurativa e é realizada através do acordo estabelecido entre as partes no processo dialogado. Para a reparação, são fundamentais os valores da responsabilidade, consensualidade e razoabilidade.

Primeiramente, para existir a reparação, deve estar presente a consensualidade entre os protagonistas sobre os fatos essenciais relativos ao delito e assunção de responsabilidade pelo infrator.

\footnotetext{
38 Jaccoud (2005, p. 171) expressa preocupação acerca dos círculos de sentença, pois existem alguns círculos em que, sem a reunião das medidas restaurativas, recomendam encarcerar o autor do delito. Segundo a autora, esses círculos não podem ser considerados restaurativos. Ainda, na opinião de Larrauri (2009, p.171), uma condenação de prisão não pode ser considerada como justiça restaurativa, pois não é compreensível como ela pode cumprir os objetivos de reintegrar o infrator ou reparar a vítima.
} 
Assim, apesar de a justiça restaurativa reconhecer que o ofensor também possui necessidades, o processo restaurativo não o exime de responsabilidade. Pelo contrário, há um enfoque sobre a responsabilização do ofensor, pois, se este praticou deliberadamente um dano a outra pessoa, deve ter obrigação moral de aceitar a responsabilidade pelo ato e atenuar as suas consequências.

Segundo Van Ness e Johnstone (PALLAMOLLA, 2009, p. 65), todos os que participam do processo restaurativo devem facilitar a responsabilização do ofensor em detrimento de sua estigmatização e punição, no sentido de fazê-lo assumir a responsabilidade pelo dano e repará-lo, demonstrando ser esta atitude uma forma de beneficiar os atingidos e contribuir para a sua reintegração na comunidade.

Em relação ao valor da razoabilidade ou proporcionalidade, impõe-se a ideia de que o conteúdo dos acordos deve ser pautado por regras justas, ou seja, devem ser: razoáveis, que sejam pertinentes à ofensa; proporcionais, que respeitem a gravidade do dano, e passíveis de cumprimento. Por isso é tão importante que os acordos obedeçam aos limites legais estabelecidos pelas normas jurídicas do país em que adotarem o modelo restaurativo. Por exemplo, aqui no Brasil, não se poderia adotar acordos que impusessem obrigações degradantes ou humilhantes ao ofensor, visto o princípio da dignidade humana resguardado pela Constituição Federal. Como exemplo, Braithwaite (LARRAURI, 2009, p.177-178) narra um caso emblemático ocorrido na Austrália, no qual os participantes da conferência acordaram que o jovem ofensor usasse uma camiseta com a seguinte expressão: "I am a thief”, ou seja, "Eu sou um ladrão". Esse acordo jamais pode ser caracterizado como restaurativo.

Nesse contexto, válida a observação de Leonardo Sica (2008, p.164):

$\mathrm{O}$ reconhecimento recíproco que nasce entre as pessoas diretamente envolvidas faz nascer um acordo que até pode ser diverso daquele estabelecido pela lei, mas, por ser relacionado com as expectativas dos indivíduos, deve ser, tendencialmente, mais equilibrado e congruente do ponto de vista distributivo/compensatório. Este "acordo equitativo" encontra, contudo, limites próprios e insuperáveis nas normas substanciais 
e processuais que regulam os comportamentos que deram lugar ao conflito e que não podem, de maneira alguma, serem colocadas de lado.

Assim, percebe-se que, apesar de mais abertos e flexíveis, os acordos obtidos através do processo mediado/dialogado não ocorrem ao arrepio da lei e das garantias formais.

Na verdade, como explica Larrauri (2009, p.176), os acordos devem realçar a importância de que a vítima se sinta reparada, pelas desculpas ou pela efetividade do acordo reparador, pois um objetivo da justiça restaurativa, diferentemente do modelo penal tradicional, é a satisfação das vítimas. Dessa forma, nas várias experiências restaurativas, os acordos costumam enfatizar um pedido de desculpas ${ }^{39}$ e/ou a reparação financeira ou simbólica (por exemplo, a realização de algum trabalho em favor da vítima ou voluntário) da vítima.

Ainda, no que tange à responsabilização do ofensor, importa ressaltar que, em caso de acordos não cumpridos, estes podem, segundo a literatura majoritária, ser encaminhados para o sistema penal tradicional, já que a proposta mais difundida é que a justiça restaurativa funcione como um complemento daquele ${ }^{40}$. No entanto, nessa hipótese, a assunção de responsabilidade do ofensor não pode servir como evidência de admissão de culpa no processo penal. Isso porque, por exemplo, o ofensor pode alegar em sua defesa uma excludente de culpabilidade.

Por fim, vale destacar a diferença entre o acordo restaurativo e o resultado restaurativo. O primeiro corresponde à reparação do dano acertado entre as parte, enquanto o segundo vai além e diz respeito ao real cumprimento do acordo e à efetiva restauração das partes.

\footnotetext{
${ }^{39}$ Braithwaite classifica as desculpas, o perdão ou a clemência como emergent values, ou seja, não são valores obrigatórios, apesar de desejáveis. Assim, a vítima pode querer perdoar o infrator, mas o processo restaurativo não pode obrigá-la a fazer isso. No mesmo sentido, forçar o remorso do ofensor não possui qualquer conteúdo restaurativo (PALLAMOLLA, 2009, p.64).

${ }^{40}$ Ressalta-se que há países, como a Nova Zelândia, em que a justiça restaurativa é considerada um modelo autônomo e, assim, não se submete ao crivo do sistema penal.
} 


\subsubsection{RESTAURAÇÃO}

A verdadeira restauração dos protagonistas do conflito, bem como da comunidade, dá-se na medida em que a justiça restaurativa busca o valor da transformação das pessoas, criando vínculos de compreensão, tolerância e solidariedade. Transforma-se porque a exclusão cede lugar à inclusão.

A restauração é possível porque se atende a todos os envolvidos no conflito: o autor, pois escapa dos malefícios do cárcere, da prisionalização e se responsabiliza pelo mal causado; a vítima, porquanto pode ter o seu dano (material e/ou moral) reparado, propende a não exibir traumas e, ainda, tem a oportunidade de conhecer melhor o ofensor, avaliando sua atitude e as circunstâncias que o conduziram ao ato delituoso e, por fim, a comunidade que tem a oportunidade de desempenhar um papel proativo no favorecimento da paz pública e da reinserção social do vitimário. Essa verdadeira restauração transcende o retorno à situação anterior e propõe a construção de uma realidade mais humana, um novo tempo, com menos insegurança e injustiça e com mais amor e responsabilidade individual e social (LEAL, 2010, p.40-41). Ainda, John Braithwaite afirma, em relação à comunidade, que a sua restauração implica restaurar a democracia participativa, a harmonia baseada em um sentimento de que se fez justiça e nas relações de apoio social (LARRAURI, 2009, p.175).

A transformação é possível porque a justiça restaurativa possibilita, no tanto quanto possível, a cura das feridas, restabelece relações e reincorpora a vítima e o ofensor na sociedade, ajudando a fortalecer o tecido social.

Howard Zehr (2008, p.176 )explica o sentido da cura:

Cura para as vítimas não significa esquecer ou minimizar a violação. Implica num senso de recuperação, numa forma de fechar o ciclo. A vítima deveria voltar a sentir que a vida faz sentido e que ela está segura e no controle. $\mathrm{O}$ ofensor deveria ser incentivado a mudar. Ela ou ele deveriam receber a liberdade de 
começar a vida de novo. A cura abarca o senso de recuperação e esperança em relação ao futuro.

Aliás, esperança é mais um valor buscado pela justiça restaurativa. Segundo Marshall, Boyack e Bowen (2005, p. 273) "não importa quão intenso tenha sido o delito, é sempre possível para a comunidade responder, de maneira a emprestar forças a quem está sofrendo, e isso promove a cura e a mudança”. Isso porque a justiça restaurativa não visa simplesmente penalizar ações criminais passadas, mas abordar as necessidades presentes e equipar para a vida futura. Assim, ela nutre esperanças: de cura para as vítimas, de mudança para os ofensores e de maior civilidade para a sociedade (Marshall, et al, 2005, p. 273).

Por fim, diante dos valores expostos até aqui, percebe-se que se os delitos forem devidamente canalizados para um modelo participativo, como o é a justiça restaurativa, pode-se construir e reconstruir laços comunitários, proporcionar a verdadeira justiça para as pessoas e, enfim, transformar valores e estruturas de uma sociedade. Assim, mesmo diante do reconhecimento de que a verdadeira ${ }^{41}$ restauração pode não ocorrer, mas se todos os princípios e valores descritos forem honrados, haverá espaço para vários processos e práticas, sem que, diante dessa flexibilidade, corrompa-se o verdadeiro sentido da justiça restaurativa.

\footnotetext{
${ }^{41}$ Pense-se nas hipóteses de acordos não-cumpridos ou de não reintegração do ofensor. Nesse sentido, Howard Zehr afirma que, evidentemente, é impossível recuperar e restaurar totalmente todos os conflitos sociais em todas as suas dimensões, mas a verdadeira justiça deve oferecer um contexto no qual os processos restaurativos possam se realizar (2008, p.176).
} 


\subsection{O PROGRAMA DE JUSTIÇA RESTAURATIVA REALIZADO NO NÚCLEO BANDEIRANTE, DISTRITO FEDERAL}

No Brasil, Pedro Scuro Neto aponta que a primeira experiência brasileira com componentes da justiça restaurativa foi o Projeto Jundiaí implantado no Estado de São Paulo, em 1998, nos ambientes escolares. O objetivo desta experiência foi possibilitar que as escolas funcionassem como sistemas de resolução de conflitos e problemas disciplinares para, assim, construírem internamente um sentido de ordem e segurança. $\mathrm{O}$ componente principal deste projeto foi a utilização das câmaras restaurativas voltadas para a solução de conflitos graves no contexto escolar (SCURO NETO, 2008, p.165166).

Esta iniciativa, no entanto, foi pontual e a justiça restaurativa só veio a ganhar mais força no cenário nacional, em 2003, com o surgimento da Secretaria da Reforma do Judiciário do Ministério da Justiça criada no intuito de estimular iniciativas de melhoramento do Poder Judiciário, pois se considerava que as soluções buscadas até então foram insuficientes para organização e aprimoramento do sistema de justiça brasileiro. Assim, o Ministério da Justiça (BASTOS, 2006, p.15) assumiu como principais objetivos: "a efetivação dos direitos e garantias inseridos na Constituição Federal"; o fomento da "democratização da justiça, práticas de justiça comunitária, de justiça restaurativa, mediação, governança da segurança pública e estratégia de ampliação do acesso à justiça"; "assegurar acessibilidade, combater impunidade, proteger a vítima de delitos, educar jovens em conflito com a lei e buscar a interação do Poder Público com a sociedade" e, ainda, a "efetivação e a promoção dos direitos dos cidadãos, possibilitando a construção de um Brasil mais seguro e a concretização do sonho de transformar o nosso país em uma verdadeira democracia de massas".

Por conseguinte, em 2005, formou-se uma parceria entre a Secretaria de Reforma do Judiciário e o Programa das Nações Unidas para o Desenvolvimento - PNUD para a 
criação do Programa "Promovendo Práticas Restaurativas no Sistema de Justiça Brasileiro". Através deste programa foi financiada a implantação de três projetos-pilotos de justiça restaurativa em estados brasileiros: em São Caetano do Sul (SP), projeto voltado para as escolas e para as infrações cometidas por crianças e adolescentes; em Porto Alegre (RS) também estruturado em torno da Vara da Infância e Juventude e em Brasília (DF) este voltado para os crimes cometidos por adultos e que foi estruturado em torno dos Juizados Especiais Criminais localizados na região do Núcleo Bandeirante. Ambos os projetos entraram em funcionamento no segundo semestre do ano de 2005.

Atualmente, no país, existem mais projetos ${ }^{42}$ de justiça restaurativa em andamento e o tema, apesar de parecer novo para muitos juristas, ganhou mais relevância no contexto jurídico brasileiro.

\subsection{CONSIDERAÇÕES METODOLÓGICAS}

Uma vez apresentada a abordagem conceitual e valores restaurativos, a fim de que se possa proporcionar uma visão mais prática da justiça restaurativa, será estudado o atual programa realizado no Núcleo Bandeirante - Distrito Federal.

A escolha da análise deste programa deu-se, principalmente, por ele ser, diferentemente dos outros projetos-pilotos, o único aplicado em relação aos delitos cometidos por pessoas adultas. A ideia era conhecer o atual funcionamento do programa para, assim, ser possível fazer confrontações entre teoria e prática.

A partir desta investigação, foi selecionado um caso de ação penal iniciada pela prática de estupro presumido que foi encaminhada ao programa do Núcleo Bandeirante. O critério para eleição deste caso deu-se por considerá-lo pertinente à verificação das

\footnotetext{
${ }^{42}$ Como exemplo, no Estado de São Paulo, já há projetos nas cidades de Higienópolis e Garulhos. Ainda, no Distrito Federal, há a experiência na cidade satélite Gama.
} 
possibilidades existentes, no atual ordenamento jurídico brasileiro, da derivação à justiça restaurativa de casos tidos como de maior potencial ofensivo.

O programa já foi objeto de pesquisas bem estruturadas e profundas. Em 2005 e 2006, foi promovida investigação pelo Instituto Latino Americano das Nações Unidas para Prevenção do Delito - ILANUD. A partir dessa investigação, em 2007, as pesquisadoras Mariana Raupp e Juliana Benedetti publicaram os resultados da pesquisa. Em 2007, foi encomendada pelo próprio Tribunal de Justiça do Distrito Federal e Territórios - TJDFT, em parceria com o Departamento de Sociologia da Universidade de Brasília, pesquisa realizada diretamente pelas sociólogas Lourdes Maria Bandeira e Analía Soria Batista. Ainda, em 2009, a pesquisadora Criziany Machado Felix, iniciou pesquisa qualitativa acerca do projeto para tese de doutoramento.

Assim, o presente trabalho pretende, a partir de uma ambição bem mais modesta, examinar os dados colhidos, nos meses de maio e junho de 2011, acerca do funcionamento do programa. A pesquisa realizada, quanto aos aspectos quantitativos, baseou-se principalmente na análise de dados secundários fornecidos pela equipe organizadora. A investigação, quanto aos aspectos qualitativos, deu-se a partir de diferentes procedimentos: análise documental; entrevista com magistrado coordenador do projeto; entrevista com os facilitadores e estagiárias; visitas in loco e participação em encontro preparatório ${ }^{43}$.

\subsection{ASPECTOS INSTITUCIONAIS}

O projeto-piloto foi instituído formalmente pela Portaria Conjunta $\mathrm{n}^{\circ} 52$, em 09/10/2006, apesar de, como dito, já funcionar desde o segundo semestre de $2005^{44}$. Com

\footnotetext{
${ }^{43}$ Devido ao valor já abordado da confidencialidade, só foi possível assistir tal encontro devido autorização das partes, no caso, das vítimas. Ainda, foi assinado um termo de confidencialidade pela autora da pesquisa a fim de garantir o sigilo, principalmente quanto aos nomes das partes, das informações prestadas no encontro. O termo consta em anexo do trabalho.

${ }^{44}$ Segundo as informações colhidas, o TJDFT, interessado nos novos modelos de solução de conflitos penais implantados com êxito em diversos países e estimulado pela Resolução n. ${ }^{\circ} 12$ da Organização das
} 
a portaria, o projeto tornou-se um serviço vinculado à Presidência do Tribunal de Justiça do Distrito Federal e dos Territórios e aos Juizados Especiais Criminais de Competência Geral do Núcleo Bandeirante ${ }^{45}$, em parceria com o Ministério Público do Distrito Federal e Territórios - MPDFT e a Defensoria Pública do Distrito Federal.

Atualmente, o TJDFT publicou, atendendo à Resolução no 125/2010 do Conselho Nacional de Justiça, a Resolução n 5 de 19/05/2011. Tal Resolução recentíssima alterou as configurações institucionais do funcionamento da justiça restaurativa no Núcleo. Dessa forma, atualmente, na estrutura interna do TJDFT, é certo dizer que os processos restaurativos são encaminhados para o "Centro Judiciário de Solução de Conflitos e de Cidadania do Programa de Justiça Restaurativa", este que compõe o "Sistema

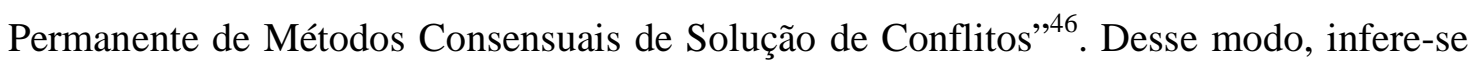
que, desde a sua implantação, a justiça restaurativa teve uma importante "evolução formal", já que deixou a antiga denominação de projeto para ser reconhecida como um programa institucional do TJDFT. A partir dessa nova denominação formal, o TJDFT pretende atuar, mais efetivamente, na promoção da solução consensual de conflitos e no atendimento e orientação dos cidadãos. Aqui, percebe-se que o projeto do Núcleo Bandeirante foi pensado, organizado e é executado com total vinculação institucional ao Poder Judiciário.

Nações Unidas, já havia publicado, em 04/06/2004, a Portaria Conjunta $n^{\circ} 15$. Tal Portaria previa a instituição de uma comissão para o estudo da adaptabilidade da justiça restaurativa no Distrito Federal, objetivando, assim, o desenvolvimento de ações para implantação de um projeto-piloto na comunidade do Núcleo Bandeirante.

${ }^{45}$ Os Juizados Especiais de Competência Geral do Núcleo Bandeirante abrangem cinco regiões administrativas do Distrito Federal: Núcleo Bandeirante, Candangolândia, Riacho Fundo I e II e ParkWay.

${ }^{46} \mathrm{O}$ "Sistema Permanente de Métodos Consensuais de Solução de Conflitos" é composto das seguintes unidades: Centro Judiciário de Solução de Conflitos e de Cidadania do Programa Justiça Restaurativa; Centro Judiciário de Solução de Conflitos e de Cidadania da Central de Apoio Judicial aos Idosos; Centro Judiciário de Solução de Conflitos e de Cidadania da Mulher em Situação de Violência Doméstica e Familiar e Centro Judiciário de Solução de Conflitos e de Cidadania do Programa Justiça Comunitária. 
A coordenação atual do programa é composta da seguinte forma: o Desembargador Roberval Casemiro Belinati é o coordenador geral do "Sistema Permanente de Métodos Consensuais de Solução de Conflitos” e os juízes Asiel Henrique de Sousa e Léa Martins são os coordenadores do "Centro Judiciário de Solução de Conflitos e de Cidadania do Programa de Justiça Restaurativa". Especificamente, para o funcionamento do programa na sede do Fórum do Núcleo Bandeirante, há uma supervisora responsável.

A estrutura do programa consta, hoje, com três servidores e duas estagiárias. Os servidores, um bacharel em direito e as outras duas psicólogas, exercem a função de facilitadores e às estagiárias, uma de psicologia e a outra de administração de empresas, dentre outras funções, cumpre a organização dos dados estatísticos do projeto. Entre os facilitadores, dois servidores são requisitados, um da TERRACAP e outro da Secretaria de Estado de Educação do Distrito Federal, e a supervisora do projeto é servidora concursada do TJDFT.

Os facilitadores foram capacitados através de curso sobre Arbitragem e Mediação do Grupo de Pesquisa e Trabalho em Resolução Apropriada de Disputas da Faculdade de Direito da UnB, sob a organização do professor André Gomma de Azevedo. Ainda, participaram de curso oferecido pelo TJDFT para a mediação de conflitos no âmbito cível.

O programa funciona no prédio do fórum do Núcleo Bandeirante (Fórum Hugo Auler) e dispõe de três salas de atendimento para pequenos círculos e uma sala para os grandes círculos, ou seja, quando os processos restaurativos envolvem um maior número de participantes. Há também uma sala reservada para a coordenação do programa, na qual a equipe técnica pode se organizar e conduzir os trabalhos e arquivos pertinentes ao projeto.

Enfim, pelo fato de o programa estar inteiramente vinculado ao âmbito de aplicação dos Juizados Especiais Criminais, instituídos pela Lei ${ }^{\circ}$ 9.099/95, são 
encaminhados ao núcleo de justiça restaurativa apenas as contravenções penais e os crimes cuja pena privativa de liberdade não ultrapasse dois anos, ambos tidos como de menor potencial ofensivo.

\subsection{FUNCIONAMENTO}

A intervenção restaurativa tem início a partir do encaminhamento dos processos judiciais iniciados nos Juizados Especiais Criminais para o programa do Núcleo Bandeirante. Para tanto, nas audiências são selecionados os casos que serão derivados à justiça restaurativa segundo os seguintes critérios:

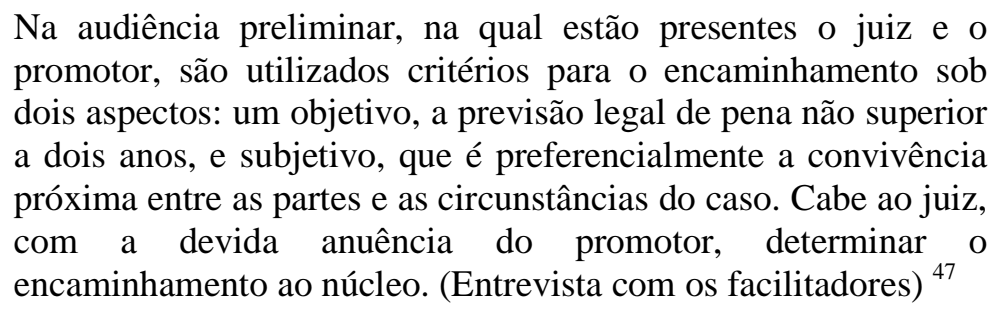

Após a verificação dessas condições necessárias do caso, as partes são informadas da existência do programa e são consultadas sobre o interesse de participação. Esse momento é de fundamental importância, pois, como visto, a voluntariedade e o consentimento informado são valores básicos da justiça restaurativa. $\mathrm{O}$ consentimento informado, segundo Larrauri (2009, p.179), é a necessidade de a parte ser informada sobre a existência da possibilidade restaurativa, da necessidade do seu consentimento e que ela pode retirar-se a qualquer momento do processo restaurativo. Percebe-se que, na prática, o programa tem cumprido a exigência de tais valores, veja-se o termo de ata de

\footnotetext{
${ }^{47}$ No vídeo de apresentação do projeto (disponível no site: http://www.youtube.com/watch?v=_VHLKN63ZUs), os magistrados envolvidos no programa ressaltam a prioridade das "relações continuadas e de proximidade". Também, o material produzido pelo projeto deixa clara a opção preferencial por esses casos. Ainda, informa-se que a entrevista realizada com os facilitadores consta em anexo do trabalho.
} 
uma audiência preliminar relativo ao crime de ameaça ocorrida na $3^{\circ}$ Vara Especial Criminal:

Nos termos do artigo 72 da Lei $\mathrm{n}^{\circ} 9.009$, os envolvidos foram esclarecidos quanto ao procedimento e efeitos da referida lei, bem assim quanto à possibilidade de encaminhamento ao Programa de Justiça Restaurativa. (...). As vítimas manifestaram interesse no prosseguimento do feito e ratificaram a representação feita na esfera policial. Perguntadas as partes se aceitavam serem encaminhadas ao programa de justiça restaurativa, por estas foi dito que aceitam tal encaminhamento. Diante de tais fatos, o Ministério Público requereu a suspensão pelo prazo de 90 dias para que as partes participem dos encontros restaurativos. (Ata de audiência preliminar relativa ao processo $\left.\mathrm{n}^{\circ} 2011.11 .1 .001115-9\right)^{48}$ (grifo nosso)

Ainda, quanto à voluntariedade das partes, percebe-se que o programa enfatiza este valor e os facilitadores ressaltam uma questão importante:

A voluntariedade das partes é fundamental para que os acordos possam ter sustentação, por isso ela deve ser bastante preservada. Caso contrário, se as partes não participarem voluntariamente, principalmente o ofensor, corre o risco de o acordo não ser cumprido ou, ainda, pode até ser cumprido, mas não altera e nem restaura efetivamente as relações. (Entrevistas com os facilitadores)

Neste ponto, é interessante abordar a fundamentação jurídica empregada pelo magistrado na Ata da Audiência preliminar: "Suspendo o processo pelo prazo de 90 dias com a concordância do Ministério Público e encaminho os autos ao Programa de Justiça Restaurativa, o que faço com fundamento no artigo $3^{\circ}$, do Código de Processo Penal c/c o artigo 62 e o artigo 89, ambos da Lei n 9.099/95." Ainda, também, como transcrito acima, utiliza-se o artigo 72 da Lei $n^{\circ} 9.099 / 95 .{ }^{49}$

\footnotetext{
${ }^{48}$ Ressalte-se que esta Ata não foi anexada, pois foi fornecida à autora uma cópia do modelo original, no qual constavam os nomes das partes. Em respeito ao princípio da confidencialidade, considerou-se prudente não torná-la pública.

${ }^{49}$ Artigo 3\%CPP: A lei penal admitirá interpretação extensiva e aplicação analógica, bem como suplemento dos princípios gerais do direito. Artigo 62/ Lei n ${ }^{\circ}$ 9.099/95: O processo perante o Juizado Especial orientarse-á pelos critérios da oralidade, informalidade, economia processual e celeridade, objetivando, sempre que possível, a reparação dos danos sofridos pela vítima e a aplicação da pena não privativa de liberdade. Artigo 72/ Lei n ${ }^{\circ}$ 9.099/95: Na audiência preliminar, presente o representante do Ministério Público, o
} 
Diante dos dispositivos utilizados, percebe-se que, por não existir expressa previsão legal quanto à justiça restaurativa nas leis processuais penais, os magistrados utilizam uma argumentação baseada em princípios. É o que sugerem, por exemplo, as expressões interpretação extensiva, princípios gerais do direito, oralidade, informalidade, objetivo de reparação dos danos sofridos pela vítima e composição dos danos constante nos artigos supracitados. Segundo o juiz Asiel Henrique de Sousa, coordenador do programa, o artigo 98 da Constituição Federal e a legislação processual penal permitiram um "espaço de consenso" entre as partes envolvidas num conflito, o que é compatível com a proposta da justiça restaurativa ${ }^{50}$.

Por conseguinte, após a seleção do caso e anuência das partes, o magistrado suspende o processo por, geralmente, noventa a cento e vintes dias, e o encaminha para a justiça restaurativa. Nesse período de suspensão, ocorrem todos os trâmites restaurativos.

As partes, ao chegarem ao centro restaurativo, geralmente acompanhadas por um estagiário do TJDFT, são recebidas pelos facilitadores. O procedimento é o seguinte:

Em havendo disponibilidade e dependendo da natureza do conflito, iniciam-se os atendimentos desde logo. Caso contrário, num prazo geralmente de dois dias, são marcados os primeiros encontros, em horários diferentes para, primeiramente, os ofensores e depois as vítimas. O ofensor é consultado primeiro porque se verifica se ele pretende realmente continuar no processo e, assim, se está disposto a dialogar e assumir responsabilidade. Caso contrário, se fosse consultada primeiro a vítima e, depois, o ofensor não quisesse mais continuar, poderia ocorrer uma nova vitimização. (Entrevista com os facilitadores)

Assim, há três fases após o encaminhamento pelo magistrado: o acolhimento, os encontros privados e os encontros restaurativos. Em ambas as fases são utilizados pelos facilitadores os conhecimentos acerca da medição penal. Toda a trajetória de atuação do programa, segundo a supervisora do projeto, é pautada na aposta da qualidade de

autor do fato e a vítima e, se possível, o responsável civil, acompanhados por seus advogados, o juiz esclarecerá sobre a possibilidade da composição dos danos e da aceitação da proposta de aplicação imediata de pena não privativa de liberdade.

${ }^{50}$ Vídeo de apresentação do projeto do Núcleo Bandeirante. 
superação do ser humano, de sair de uma condição mais adversarial, promovendo, assim, uma comunicação eficiente entre as partes ${ }^{51}$.

$\mathrm{O}$ acolhimento consiste na fase de fornecimento das informações preliminares acerca da justiça restaurativa. Segundo os facilitadores, é o momento em que tentam “estabelecer o rapport ${ }^{52}$. Aqui, neste primeiro contato, procuramos criar um vínculo de confiança com as partes" (Entrevista com os facilitadores).

Nos encontros privados, verificam-se as questões, interesses e sentimentos das partes, separadamente. Os facilitadores são imparciais e não fazem pré-julgamentos. Neste momento, segundo os facilitadores, muitas partes dizem que "querem que o juiz decida", tornando-se claro a resistência de algumas pessoas ao novo modelo proposto. Verificada resistência, os facilitadores explicam, novamente, os ônus de um processo convencional e abordam a questão da alteridade, objetivando que a parte enxergue o outro. Ainda, nessa fase, busca-se o valor do empoderamento. Os mediadores objetivam empoderar as partes, principalmente a vítima, para que se sintam aptas a participar dos encontros restaurativos.

Nesse contexto, os facilitadores foram questionados sobre a questão da celeridade dos procedimentos. Esta inquirição deu-se devido à preocupação existente na literatura referente de que as práticas restaurativas tornem-se tendenciosas a transformar a mediação em um mero instrumento de alívio rápido da carga de trabalho dos tribunais, o que não é característica dos melhores projetos restaurativos, pois estes tentam manter distância cautelosa da ideia meramente utilitarista (SICA, 2008, p.166). Foi obtida a seguinte resposta, considerada positiva:

Em média, aqui no centro, é realizado um encontro privado com cada parte. Mas, o critério que utilizamos é o empoderamento

\footnotetext{
${ }^{51}$ Vídeo de apresentação do Projeto Núcleo Bandeirante.

52 Rapport é um termo utilizado na mediação penal e significa o estabelecimento de uma relação de confiança entre o mediador e as partes envolvidas no conflito. O rapport é possível quando o mediador atua com base nas seguintes estratégias: sensibilidade, receptividade, imparcialidade, postura nãopreconceituosa, reconhecimento e validação dos sentimentos das partes, desporalização do conflito, etc. (AZEVEDO, 2009, p.133-139)
} 


\begin{abstract}
dos envolvidos. São as partes que ditam o ritmo e não nós, pois a preocupação é de oferecer um bom atendimento, uma verdadeira resolução do conflito. Assim, serão, na prática, realizados quantos encontros forem necessários. Inclusive, muitas vezes, fazemos atendimentos domiciliares, que levam mais tempo, para melhor atendê-los no seu contexto (Entrevista com os facilitadores)
\end{abstract}

Em relação, ainda, aos encontros privados, os facilitadores devem, se possuírem vínculos sociais ou simplesmente conhecerem algum dos envolvidos, informar a situação às partes, em atenção ao princípio da imparcialidade. Foi presenciada pela autora tal conduta dos mediadores, quando da oportunidade de participar de um encontro privado em relação ao um caso que envolvia de conflito de vizinhos ${ }^{53}$ por perturbação de sossego. Neste pré-encontro assistido, os facilitadores iniciaram a conversa abordando a questão da importância da neutralidade, pois um dos facilitadores conhecia uma pessoa que funcionaria como apoiadora da ofensora. Daí, o mediador expôs a situação e consultou as partes para saber se elas permitiriam que ele continuasse no caso ou se preferiam outro facilitador. Na oportunidade, as partes que eram vítimas, não se opuseram à situação. $\mathrm{O}$ que permite aferir que as vítimas já tinham estabelecido uma relação de confiança com o mediador inicial.

Ainda, quanto ao encontro em destaque, importante ressaltar uma observação. As vítimas eram casadas. No entanto, em um momento determinado do encontro, quando o marido veio a se retirar da sala, a esposa conversou com a facilitadora e contou que sofria violência doméstica, por isso, naquele dia, estava com o braço engessado. Ao fim do encontro, os facilitadores demonstraram preocupação acerca da revelação e combinaram de analisar e conversar posteriormente sobre o fato, já que eles possuem o dever legal de comunicar à justiça os fatos graves subjacentes ao encontro. Tal postura vai ao encontro dos princípios restaurativos, pois conforme Elena Larrauri (2009, p.181), baseando-se nas diretrizes jurídicas européias, "apesar do princípio da confidencialidade, (os facilitadores) devem informar às autoridades sobre qualquer delito grave futuro".

\footnotetext{
${ }^{53}$ Encontro privado assistido no dia 25.05.2011. Por norma do programa, não foi fornecido o número do processo.
} 
O encontro restaurativo, por sua vez, é o momento em que as partes encontram-se diretamente e podem expor suas emoções e conflitos, percebendo que serão respeitadas quanto a isso. "Todos os sentimentos são legítimos, sejam quais forem, devem ser respeitados" (Entrevista com os facilitadores). Neste momento, os facilitadores utilizam técnicas de mediação vítima-ofensor e as partes discutem sobre a melhor forma de resolver o conflito. No entanto, os mediadores devem conduzir e estimular um diálogo respeitoso, outro valor restaurativo. Segundo os facilitadores:

Há regras para um diálogo ser respeitoso e produtivo. Não admitimos ironias, nem sarcasmos, nem provocação e nem desqualificação, pois as partes devem ser igualmente tratadas de forma respeitosa. Orientamos sobre a forma de um diálogo livre, mas sem comunicação violenta. (Entrevista com os facilitadores)

Em relação à participação da comunidade, valor tão preservado pela justiça restaurativa, o programa enfatiza a participação de familiares, vizinhos, etc., ou seja, os facilitadores convidam todas as pessoas que eles ou as partes considerem importantes para a solução do conflito. No programa, essas pessoas são denominadas de apoiadores. Segundo o entendimento dos facilitadores:

A comunidade gera empoderamento às partes. Os apoiadores servem de padrinhos, pois ajudam a sustentar o acordo. Caso contrário, também o acordo fica sem lastro. A comunidade como apoiadora contribui para a paz social e para a justiça. O critério para escolher os apoiadores não é apenas a proximidade, mas também o poder de negociação que eles têm no conflito, ou seja, o poder de interferir na relação. Funcionam como mesas de negociação. Como exemplo: teve um caso de lesão corporal ocorrido na porta de uma igreja e tanto a vítima como o ofensor freqüentavam a mesma igreja. Nós convidamos o padre da paróquia para funcionar como apoiador. (Entrevista com os facilitadores)

Ao final do encontro restaurativo, as partes assinam um "Termo de Acordo Restaurativo" ${ }^{\circ 4}$, geralmente padronizado, mas obviamente sem desconsiderar as circunstâncias e os contextos diversos. Os facilitadores, a partir das experiências vividas no programa, relatam que:

\footnotetext{
${ }^{54}$ Foi obtido um modelo de Termo de Acordo Restaurativo, que consta em anexo.
} 
Na maior parte dos casos, as vítimas aceitam um pedido de desculpas como reparação. Pouquíssimos casos se concentram no conteúdo financeiro. $\mathrm{O}$ facilitador não pode jamais forçar a realização e nem o conteúdo de um acordo, pois ficaria prejudicada a autonomia das partes e a restauração. Nós ficamos atentos apenas para que não haja nenhuma lesão aos direitos das partes. (Entrevista com os facilitadores)

Finalizadas todas as etapas (acolhimento, encontros privados e encontros restaurativos), abrem-se duas possibilidades: na hipótese de realização do acordo, este será homologado pelo juiz, promotor e defensor, particular ou público, enquanto que, em não havendo acordo, retorna-se com o seguimento do processo penal convencional.

\subsection{DADOS ESTATÍSTICOS}

Através da análise documental fornecida pela equipe técnica, foi possível organizar os seguintes dados:

\begin{tabular}{|l|l|l|l|l|}
\hline ANO & $\begin{array}{c}\text { PROCESSOS } \\
\text { INICIADOS }\end{array}$ & $\begin{array}{c}\text { ACORDOS } \\
\text { ACORO } \\
\text { REALIZADOS }\end{array}$ & REALIZADOS & REINCIDÊNCIA \\
\hline 2005 & 21 & 6 & 14 & 0 \\
\hline 2006 & 24 & 13 & 11 & 0 \\
\hline 2007 & 37 & 21 & 16 & 0 \\
\hline 2008 & 27 & 23 & 4 & 0 \\
\hline 2009 & 43 & 33 & 10 & 2 \\
\hline 2010 & 71 & 46 & 25 & 3 \\
\hline
\end{tabular}

Partindo do gráfico, tem-se que, no período de 2005 a 2010, foi encaminhado o total de 223 processos à justiça restaurativa. Deste total, em 142 foram obtidos acordos e em 80 casos as partes não acordaram. Ainda, somente no ano de 2009 e 2010, é que 
foram verificadas práticas reincidivas, porém, não foi possível confirmar se a reincidência deu-se pela prática dos mesmos delitos ou de delitos considerados mais ou menos graves, o que seria relevante. Como complemento desta informação meio imprecisa, oportuno o posicionamento dos facilitadores:

Não nos recordamos de nenhum caso em que foi realizado acordo e que tenha voltado para cá. Mas, quanto aos casos que as partes não fizeram acordo, teve pouquíssimos que voltaram. Estimamos, senso comum mesmo, que a proporção é de 1 ofensor reincidente dentro de 100 casos encaminhados. Pelo que lembramos, os casos em que houve reincidência foram de ameaça e lesão corporal. Nesses, havia algum tipo de dependência química por parte dos agressores. Por enquanto, carecemos de pesquisas qualitativas quanto à reincidência. (Entrevista com os facilitadores)

Os mais recentes dados obtidos do ano de 2011 são referentes até o mês de maio, quais sejam: realização de 24 acolhimentos, 372 (encontros privados, telefonemas e visitas domiciliares a somente uma das partes) e 13 encontros restaurativos. Nestes últimos, não foi possível contabilizar o número de acordos realizados ou não, visto que muitos processos restaurativos ainda estão em curso.

Em relação à incidência penal, no universo de 236 casos encaminhados ao programa, tem-se a seguinte configuração ${ }^{55}$ :

\begin{tabular}{|l|c|l|c|}
\hline TIPIFICAÇÃO & QUANTIDADE & TIPIFICAÇÃO & QUANTIDADE \\
\hline $\begin{array}{l}\text { Lesão corporal leve } \\
(\text { artigo 129/CPB) }\end{array}$ & 61 & $\begin{array}{c}\text { Calúnia } \\
(\operatorname{artigo~138/CPB~})\end{array}$ & 8 \\
\hline \multicolumn{1}{|l}{$\begin{array}{l}\text { Injúria } \\
\text { (artigo 140/CPB) }\end{array}$} & 45 & $\begin{array}{c}\text { Desacato } \\
(\text { artigo 331/CPB })\end{array}$ & 6 \\
\hline
\end{tabular}

\footnotetext{
55 Os dados quanto à natureza dos delitos não são precisos. Aqui, procurou-se fazer uma estimativa aproximada, visto que alguns dados fornecidos contêm algumas imprecisões ou autora teve dificuldades para afirmá-los. A intenção é apenas mostrar um panorama geral aproximado, ao máximo, da prática do programa. Ressalta-se que, na tabela, foram expostos apenas os casos que representaram uma quantidade maior que quatro. A soma do quadro resulta em 213 casos.
} 


\begin{tabular}{|l|c|l|c|}
\hline \multicolumn{1}{|c|}{$\begin{array}{l}\text { Ameaça } \\
\text { (artigo 147/CPB) }\end{array}$} & $\begin{array}{l}\text { Perturbação da } \\
\text { tranqüilidade } \\
\text { (artigo 65/LCP) }\end{array}$ & 18 \\
\hline $\begin{array}{l}\text { Perturbação do } \\
\text { trabalho ou do } \\
\text { sossego alheio } \\
(\text { artigo 42/LCP }\end{array}$ & 11 & $\begin{array}{c}\text { Dano } \\
\text { (artigo 163/CPB) }\end{array}$ & 13 \\
\hline $\begin{array}{l}\text { Lesão culposa no } \\
\text { trânsito (303/CTB }\end{array}$ & 5 & $\begin{array}{c}\text { Vias de fato } \\
(\operatorname{artigo~21/LCP)~}\end{array}$ & 7 \\
\hline
\end{tabular}

A partir deste quadro, percebe-se que a prática da justiça restaurativa no Núcleo Bandeirante tem, realmente, voltado-se apenas para os delitos de menor potencial ofensivo ou crimes de bagatela. Em termos de porcentagens, o quadro acima representaria: lesão corporal leve- 25\%; injúria -19\%; ameaça $-18,6 \%$; perturbação $13 \%$; dano - 5,5\%; lesão culposa no trânsito - 2,5\% e outros correspondendo a $17,5 \%$. Quando aos outros tipos penais, vale ressaltar que houve, ainda, encaminhamento de outros casos previstos no Código Penal Brasileiro (maus-tratos, constrangimento ilegal, violação de domicílio, exercício arbitrário das próprias razões, alteração de limites, difamação e desobediência) e na Lei de Contravenções Penais (exercício ilegal da profissão, crueldade contra animais e omissão de cautela na guarda ou condução de animais).

\subsection{OBSERVAÇÕES}

Inicialmente, cabe ressaltar que este estudo realizado no Centro Judiciário de Justiça Restaurativa não tem o objetivo de desenvolver postulados teóricos que pretendam à generalização de casos. Tampouco, visto a simplicidade da pesquisa,

\footnotetext{
${ }^{56}$ Lei das Contravenções Penais $n^{\circ} 3.688 / 41$.

${ }^{57}$ Código de Trânsito Brasileiro/ Lei n ${ }^{\circ}$ 9.503/97.
} 
pretende-se uma completa avaliação do programa. No entanto, impossível seria não formular alguns comentários, já que existiu, de fato, ainda que simplória, uma observação.

Com afirmam Marshall, Boyack e Bowen (2005, p.273) para que os processos tenham verdadeiramente um caráter restaurativo devem evidenciar os valores-chaves da justiça restaurativa. Assim, se relacionarmos o funcionamento do projeto e os valores restaurativos, ambos já trabalhados, percebe-se que o programa tem atendido e respeitado a estrutura axiológica prioritária da justiça restaurativa. Isso porque as posturas dos facilitadores convergem para uma atuação competente, imparcial e que busca a confiança dos participantes e da comunidade em geral. Um ponto extremamente positivo percebido, em geral, foi que os membros da equipe técnica, aos quais se teve acesso, ofertam uma enorme dedicação ao projeto e crêem num ideal de justiça diverso, ainda que em diferentes graus, da concepção repressiva tradicional. Ainda, como visto, os processos restaurativos são acompanhados com verdadeira atenção aos princípios restaurativos.

Segundo Juliana Benedetti, ao analisar detalhadamente um caso entre concunhados envolvendo ameaça e lesão corporal e que foi trabalhado pela justiça restaurativa, as partes concordaram que o processo restaurativo evitou o agravamento do conflito e disseram estar satisfeitas. Ambas as partes disseram, ainda, que se sentiram aliviadas com o fato de o sistema de justiça ter sido capaz de prover-lhes uma solução adequada. A pesquisadora relatou o posicionamento da vítima: "aquela mágoa, aquele ressentimento acabou. No começo, eu sentia muita raiva. (...) Foi bom porque conversei com ele, na rua a gente talvez não teria essa oportunidade. Fiquei surpreso com a fala dele e com o pedido de desculpas" (2009, p.82-83).

Portanto, pode-se dizer que o programa em questão, naquilo que se propõe, deve ser considerado um programa de grande qualidade restaurativa.

Outro ponto considerado de muita relevância foi a atuação esporádica do programa no âmbito civil. Tal questão foi observada quando da participação em encontro 
privado, já citado, que envolvia briga de vizinhos. No encontro, os facilitadores perceberam que havia uma questão de guarda de menores como subjacente ao conflito. $\mathrm{Na}$ oportunidade, ofereceram-se para restaurar este aspecto do conflito, pois se não trabalhado não poderia ser encerrado o ciclo de desentendimentos que desencadeava as brigas. Foi explicado que realizado o acordo civil, este é levado para a homologação no juízo competente. As partes afirmaram que iriam pensar sobre isso. Essa atuação é importante na medida em que demonstra o objetivo real do projeto em restaurar e compor os conflitos em sua totalidade possível. Ainda, denota a flexibilidade da atuação da justiça restaurativa em várias dimensões.

Por outro lado, Marshall, Boyack e Bowen (2005, p.273) destacam a tendência de que alguns projetos de justiça restaurativa possuem de enfatizar somente o que tem funcionado, ou seja, os melhores aspectos, deixando de efetuar uma avaliação mais honesta, que contribua para a melhora da prática. Assim, sabendo-se que observar uma atitude tão inovadora e louvável, como é o programa em questão, pode nos levar à dita tendência, é que serão destacados alguns pontos, não negativos, mas considerados insuficientes, visando apenas à fomentação de um projeto cada vez melhor.

No Núcleo Bandeirante, foi observada que, mesmo havendo certo controle em termos de aspectos quantitativos, não houve, durante esse período - 6 anos - de funcionamento do projeto, uma avaliação qualitativa constante e mais profunda acerca da própria atuação e dos resultados do programa. Os números não são suficientes para avaliar um programa restaurativo. Assim, quando se tratou da possibilidade de analisar relatórios ou questionários respondidos pelas partes, foi relatado o seguinte: "em termos quantitativos, há gerenciamento no projeto. Porém, atualmente, desde março (2011), é que os relatórios e questionários de avaliação estão sendo entregues, havendo ou não acordo, para todas as partes. Antes não existia essa metodologia, era apenas esporadicamente" (Entrevista com os facilitadores) ${ }^{58}$.

\footnotetext{
${ }^{58}$ Quanto ao questionário de avaliação foi fornecido o novo modelo de pesquisa de opinião, em anexo, que começou a ser entregue aos participantes. Acredita-se que esse novo modelo contempla uns dos principais
} 
Essa ausência de avaliação densa é uma preocupação constante entre os teóricos restaurativos. Nesse sentido, Howard Zehr (2006, p. 414):

Nós precisamos de avaliação e precisamos prestar atenção aos
resultados. Nós, que somos partidários e profissionais da justiça
restaurativa, naturalmente acreditamos que estamos fazendo um
maravilhoso trabalho. Como alguém poderia duvidar disso? Nós
relatamos as histórias de sucesso e ignoramos as ruins - como
colecionar borboletas, acusam nossos críticos. Como resultado
dessa mentalidade, nós temos a tendência de não querer
avaliações. Quando somos avaliados, nós não queremos saber os
resultados. Nós precisamos urgentemente de avaliações que
devem empregar vários métodos e vários enfoques. Precisamos
avaliar os processos, os resultados, bem como os objetivos e o
funcionamento das nossas organizações. (grifo nosso)

Acredita-se que a razão subjacente a essa dificuldade de constante e profunda avaliação do projeto pode estar na relação inversamente proporcional, entre o número de facilitadores e casos encaminhados, que o programa tem experimentado nesses anos. Isso porque, atualmente, como relatado por esta pesquisa, o centro conta com três facilitadores e duas estagiárias, todos responsáveis pelo levantamento de dados. No entanto, como atestado pela investigação do ILANUD, no período de 2005-2006 havia o número de vinte e dois facilitadores ${ }^{59}$ (RAUPP; BENEDETTI; 2007, p.14). Assim, observando-se a tabela de dados estatísticos, vê-se que aumentou o número de casos encaminhados enquanto o número de facilitadores diminui drasticamente. Talvez, então, dispondo de uma menor equipe técnica, tenham surgido dificuldades para operacionalizar as avaliações. No entanto, como visto, de qualquer forma, é imprescindível uma avaliação de qualidade.

Ainda, em relação ao número de facilitadores, entende-se que um número enorme deles talvez não seja tão imprescindível, pois, num projeto onde existe uma elevada quantidade de atores, pode-se chegar à conclusão de que todo mundo está participando de um jogo diferente e que nem todos estão vendo as coisas da mesma forma, trazendo,

objetivos da justiça restaurativa, quais sejam a satisfação das partes e a experiência de ter participado de um processo mais justo e eficaz.

${ }_{59}$ Pedro Scuro Neto (2008, p.173) explica que, no caso dos projetos-piloto brasileiros, pôde ser verificado que, no início da implantação, deu-se ênfase numa formação aligeirada de um "batalhão de facilitadores". 
assim, implicações bastante sérias (ZEHR, 2006, p. 414). Acredita-se que, no atual estágio, a atuação dos facilitadores do projeto, apesar de em número menor, é caracterizada por significativa coerência entre eles.

Ainda, no Núcleo Bandeirante, por ser um programa restrito aos casos de bagatela, pode-se estar incorrendo em outro grande temor da justiça restaurativa: o problema da extensão da rede de controle. Segundo a pesquisadora Criziany Machado (2010, p. 14), ao analisar o projeto em questão, "constatou-se que a justiça restaurativa propicia um controle social informal mais abrangente, pelo que se questiona se isso deveria ou não ser evitado". Também, como exposto nos dados levantados, foram encaminhados para o Núcleo, por exemplo, tipos penais de crueldade contra animais (artigo 64/LCP) e omissão de cautela na guarda ou condução de animais (artigo 31/LCP). Casos estes em que seria impossível a identificação da vítima e reparação do dano, elementos essenciais à justiça restaurativa. Tipos penais que, apesar de representarem condutas indesejadas, certamente não chegariam ao sistema penal. Por ser a extensão da rede de controle um dos argumentos de defesa deste trabalho será adiante aprofundado.

A partir dessas breves observações pode-se concluir que o atual funcionamento do programa do Núcleo Bandeirante tem realizado uma prática condizente, competente e satisfatória quanto aos valores restaurativos e, uma vez superadas as questões aqui trabalhadas, pode se consolidar como uma prática restaurativa de grande potencial transformador das pessoas, dos conflitos e da justiça.

\subsection{ESTUDO DE CASO}

Neste ponto, analisaremos o caso encaminhado, em 2007, pela $2^{\mathrm{a}}$ Vara Criminal de Samambaia, para o programa de justiça restaurativa do Núcleo Bandeirante que envolveu a conduta típica de estupro presumido prevista no artigo 213 , § único, do 
Código Penal Brasileiro ${ }^{60}$, qual seja: “Art. 213: Constranger mulher à conjunção carnal, mediante violência ou grave ameaça. Parágrafo único: se a ofendida é menor de catorze anos. Pena - reclusão, de seis a dez anos.” Ressalta-se que, a legislação brasileira à época dos fatos, já incluía este tipo no rol dos crimes hediondos, de acordo com a Lei $\mathrm{n}^{\circ}$ $8.072 / 90$.

\subsubsection{DEMILITAÇÃO DO OBJETIVO}

Antes de iniciar a apresentação do caso, é imprescindível fazer alguns esclarecimentos. Primeiramente, é preciso asseverar que a aplicação da justiça restaurativa em relação aos crimes sexuais é um dos grandes pontos de debates e divergências entre os autores. Ainda, quando relacionado especificamente às mulheres, é preciso reconhecer que, como bem explica Rachel Fiel (2005, p.393):

Os ambientes dos encontros restaurativos não são isentos das
estruturas patriarcais persistentes na sociedade e nas famílias. A
força da desvantagem que as mulheres podem sofrer, em
contextos de resolução informal de conflitos está diretamente
relacionada a questôes de poder relativas aos gêneros que afetam
sua habilidade geral de defender efetivamente seus próprios
direitos.

Diante dessas considerações, é preciso especificar que a escolha deste caso como paradigmático deu-se primariamente por representar uma atitude inovadora perante sistema penal brasileiro e também por ter sido o único caso de maior potencial ofensivo encaminhado para o programa. Dessa forma, o caso importa pela relevância das reflexões que dele se pode formular acerca da abertura do sistema brasileiro para a justiça restaurativa. Portanto, não será objeto deste estudo a análise e discussão das possíveis relações de gênero que poderiam ter sido relevantes tanto para a anuência e

\footnotetext{
${ }^{60} \mathrm{O}$ caso ocorreu no ano de 2007. Assim, antes das alterações legislativas incluídas pela Lei n 12.015/09 que modificou o tipo penal de estupro presumido para o atual estupro de vulnerável (art.217-A/CPB).
} 
encaminhamento do caso quanto aos próprios processos restaurativos realizados pela equipe do programa.

\subsubsection{O CASO E A JUSTIÇA RESTAURATIVA}

Ressalte-se que todos os dados fáticos descritos a seguir foram colhidos a partir de entrevista com uma das facilitadoras que participou diretamente do processo restaurativo e com a juíza do caso. ${ }^{61}$

Tratou-se de situação que envolveu três jovens, dois maiores de 18 anos e um menor de idade (encaminhado para a Vara da Infância e da Juventude) e uma menina (denominada N) de 13 anos de idade. Apenas um dos jovens (denominado E) manteve relação sexual com a menor, enquanto o outro (denominado L) apenas o acompanhara. Os rapazes alegaram que houve concordância de N. para se relacionar com E, ela não teria oferecido nenhuma resistência, por isso acreditavam ser inocentes.

Durante a instrução processual, os pais da vítima e a vítima encontravam-se para acompanhamento psicossocial com as psicólogas do Centro Psicossocial do TJDFT, que também eram facilitadoras do programa do Núcleo Bandeirante. Durante os encontros, as psicólogas (COSTA; MOURA, 2008, p.614) relataram que:

(...) a mãe demonstrou o imenso sofrimento que o fato havia lhe causado, principalmente porque também havia sido vítima de estupro quando adolescente, e esse fato implicará em reviver a agressão sofrida no passado. (...). Mencionou o desejo de falar com os agressores e da sua dor por não ter sido autorizada a

\footnotetext{
${ }^{61}$ As duas psicólogas, que também foram facilitadoras deste caso, produziram um artigo, incluído na bibliografia, no qual descreveram detalhadamente as peculiaridades do caso e as etapas do processo restaurativo. Também, foram obtidos trechos da sentença penal relativo ao processo. No intuito de resguardar a identidade das partes, não foi permitido pela magistrada a exposição do número do processo e, evidentemente, dos nomes das partes, estas serão descritas apenas com as letras iniciais dos seus respectivos nomes. Impede ressaltar que a magistrada, na entrevista concedida, relatou estar viabilizando o encaminhamento de dois casos de roubo, também crime de maior potencial ofensivo, para à justiça restaurativa.
} 
ouvir o depoimento dos acusados que acontecera na mesma tarde.

As psicólogas falaram sobre a existência do programa de Justiça Restaurativa do Núcleo e explicaram aos pais da vítima que eles poderiam conversar tanto com os ofensores quanto com os genitores destes. Na oportunidade, abordaram, em geral, os valores restaurativos. Por conseguinte, precisamente na audiência de oitiva das testemunhas, as psicólogas informaram à juíza sobre a concordância e o desejo da mãe de participar da justiça restaurativa, pois esta queria conversar com os agressores de sua filha, uma vez que eram conhecidos da comunidade.

A magistrada relatou sobre uma resistência inicial, por se tratar de crime hediondo, mas consentiu pelo encaminhamento ao programa, conforme descreveu na parte do relatório contida na sentença final:

Diante da manifestação do desejo da mãe da vítima, e após consulta às partes, em especial aos advogados de defesa e ao Ministério Público, os quais unanimemente anuíram, foi deferido a instauração de procedimento restaurativo, nos moldes implantados no projeto piloto do Núcleo Bandeirante, oportunidade em que houve advertência expressa por parte deste Juízo sobre a natureza extraprocessual dos encontros, que ocorreriam sem afetar o curso da ação penal. Na mesma oportunidade, foi esclarecido ainda que os encontros seriam realizados, primordialmente, com a finalidade de restaurar as relações afetadas pelo ocorrido, em especial naqueles aspectos que não são alcançados no âmbito da Justiça Penal, portanto, sem o condão de anular o processo penal, sobretudo, em razão da indisponibilidade da ação penal. Na mesma oportunidade, foi alertado ainda que o procedimento restaurativo não poderia ser utilizado como prova de âmbito desfavorável à defesa dos réus nos autos principais. (TRECHO DO RELATÓRIO DA SENTENÇA)

Assim, o processo foi suspenso na esfera criminal e iniciaram-se os procedimentos restaurativos no Núcleo Bandeirante com equipe multidisciplinar. No centro, foram realizadas todas as etapas (acolhimento, encontros privados $\mathrm{e}$ restaurativos), inclusive com visitas domiciliares, enfatizando-se sempre os valores restaurativos. Durante o encontro restaurativo, participaram como apoiadores os genitores 
dos ofensores e da vítima e outros familiares, a patroa da mãe do ofensor E e o patrão de L. A proposta dos pais da vítima era que o ofensor E trabalhasse por três meses numa instituição que amparasse mulheres vítimas de violência sexual, doméstica ou mães solteiras grávidas.

Finalizados os procedimentos no programa, os envolvidos disseram-se satisfeitos com o processo restaurativo. Os ofensores expressaram estar verdadeiramente arrependidos com o ato e seus pais acreditam que eles tiveram um "crescimento pessoal" com a experiência. A vítima declarou ter se sentido mais segura e pôde, com as suas palavras, falar sobre o trauma vivido. Ainda, como surgiram muitas ameaças entre os irmãos da vítima para com os ofensores e certo "medo" na vizinhança, a situação "criou um clima de insegurança e belicosidade que facilmente se transformaria em causa de novas violências" (COSTA;MOURA, 2008, p.624). Assim, "o caminho da justiça restaurativa foi adequado e permitiu a recomposição do tecido social e impediu que comentários promotores de violência encontrassem ouvidos atentos" (COSTA; MOURA, 2008, p.624).

Por conseguinte, foi enviado um relatório de toda a abordagem restaurativa do caso para o juízo criminal, com o fim de reiniciar o processo.

Neste ponto, vale destacar a posição das facilitadoras (COSTA; MOURA, 2007, p. 624-625) responsáveis por essa experiência, quando da restrição da justiça restaurativa aos crimes de menor potencial ofensivo:

Este caso é uma importante demonstração que o Programa de
Justiça Restaurativa é possível de ser aplicado em processos que
tratem de crimes graves envolvendo maiores. (...). Este caso foi
um passo dado pelo Programa de Justiça Restaurativa do Núcleo
Bandeirante-DF no sentido de ampliar a atuação dessa nova
forma de lidar com os crimes de grande potencial ofensivo. (...).
Esse é o próximo desafio. Este caso demonstra que vale a pena
aceitá-lo.

Diante da impossibilidade de descrever todos os fatos de forma detalhada, bem como abordar todo o teor dos encontros privados e restaurativos, importa demonstrar os 
principais fundamentos utilizados pela magistrada, ao acolher a justiça restaurativa como fator preponderante para a atenuação da pena do ofensor.

\subsubsection{FUNDAMENTOS DA SENTENÇA}

Após o relatório do caso, a sentença segue destacando o ponto da aplicação da justiça restaurativa aos crimes ditos de maior potencial ofensivo. Nos termos da sentença, pelo fato de serem crimes mais graves, como o caso em questão, aponta-se para a impossibilidade da total substituição do processo penal formal pelas práticas restaurativas, visto a indisponibilidade da ação penal incondicionada ou condicionada à representação, explicando, ainda, que, para que haja o encaminhamento à justiça restaurativa, deve existir a voluntariedade e consensualidade das partes. No entanto, destaca-se importantíssimo trecho da sentença:

Insta observar, no entanto, que a natureza indisponível da
ação penal não desconstitui, tampouco diminui a importância
da aplicação de práticas restaurativas nos delitos graves, na
medida em que "a intervenção restaurativa parte do pressuposto
de que, antes mesmo de constituir uma violação à lei, a agressão
se traduz, em termos individuais e psicoafetivos (...). Tendo em
conta os benefícios para a vítima (materiais, econômicos, sócias,
morais e de segurança) e para o ofensor (morais, sociais e
judiciais) (...), o processo de mediação pode revelar-se de grande
utilidade. (TRECHO DA FUNDAMENTAÇÃO DA
SENTENÇA) (grifo nosso)

Ainda, a sentença afirma que, no presente caso em comento, na medida em que a comunidade dialogou acerca dos problemas decorrentes do crime, enfrentando-o de maneira interessada e responsável, "não há dúvida que a despeito da penalidade aqui atribuída ao réu E; este, com o apoio recebido por meio dos encontros restaurativos, encontrará sentido para afastar-se da estigmatização e rotulação, próprias da aplicação isolada das medidas inerentes ao sistema formal de justiça". (TRECHO DA FUNDAMENTAÇÃO DA SENTENÇA) 
Ao longo de toda a fundamentação, percebe-se que a sentença reporta-se à reestruturação do equilíbrio das relações interpessoais e compreensão do conflito pelas partes propiciada pela justiça restaurativa. Esta entendida como fator de reinclusão do ofensor no seio da sociedade.

A partir de todas essas considerações e, diante do fato de que o sistema penal se mostra muito fechado e rígido, principalmente quanto aos crimes hediondos, à magistrada, diante da importância da justiça restaurativa, coube considerar os resultados restaurativos na dosimetria da pena. Assim, na parte dispositiva determinou:

Ao final, (...), fixando-a, DEFINITIVA E CONCRETA, em $\underline{07}$ (SETE) ANOS DE RECLUSÃO. Embora o $\$ 1 .^{\circ}$ do art. $2 .^{\circ}$, da Lei 8.072/90, tenha mantido o regime inicialmente fechado para os crimes considerados hediondos, entre os quais, os de natureza sexual, a aplicação do referido regime para o caso em comento não encontra sustentação diante da especificidade do caso, senão vejamos. Depreende-se das informações dos autos que a situação foi especialmente tratada pelas partes nos encontros restaurativos, no sentido de recomporem as relações por ela afetadas, o que sem dúvida contribuiu para a pacificação social, um dos objetivos que se espera da justiça penal. Nesse aspecto, importa observar que a resposta penal deve guardar razoabilidade, à luz dos critérios da necessidade e suficiência de pena para o caso concreto, sob o risco de se afrontar o princípio da individualização da reprimenda, previsto no inc. XLVI do art. 5. ${ }^{\circ}$ da Constituição Federal. Assim, diante das ponderações acima e levando em conta as diretrizes expostas no art. 33, $\S 2^{\circ}$, "b" e $\S 3^{\circ}$ do CPB, tenho como suficiente para o caso em comento a fixação tão-somente do regime semi-aberto para o cumprimento da pena. (TRECHO DA PARTE DISPOSITIVA DA SENTENÇA)

Diante do caso analisado, percebe-se que a fundamentação jurídica utilizada atentou-se à realização de princípios maiores do direito, tais como a proporcionalidade e razoabilidade da pena, bem como o ideal de pacificação social por meio da justiça penal foi um valor abalizador da sentença. Assim, infere-se que a justiça restaurativa deve e pode, cada vez mais, ganhar espaço no cenário pátrio. Isso porque o nosso ordenamento, 
apesar de ainda rígido e fechado às práticas restaurativas para crimes de maior potencial ofensivo, permite que magistrados conscientes do verdadeiro papel da justiça nas relações sociais, como a juíza do caso, encontrem, se vierem a procurar, espaços possíveis para a construção de argumentos sociais e jurídicos. Portanto, esse caso nos deixa uma "porta aberta" para a consideração de novas possibilidades da justiça restaurativa no sistema de justiça penal brasileiro. 


\subsection{NOVAS POSSIBILIDADES: A DERIVAÇÃO À JUSTIÇA RESTAURATIVA DOS TIPOS PENAIS MAIS GRAVES NO SISTEMA PENAL BRASILEIRO}

Como visto, no Brasil, as primeiras experimentações da justiça restaurativa foram arquitetadas a partir de uma total vinculação institucional aos órgãos jurisdicionais. No entanto, apesar de que seria muito desejável que as práticas restaurativas, desde logo, se realizassem num contexto puramente autônomo e comunitário, reconhece-se a importância de que elas, no cenário brasileiro, se relacionem com o modelo de justiça tradicional. Isso porque, vale lembrar, que a nossa Constituição Federal consagra o princípio da inafastabilidade da jurisdição no artigo $5^{\circ}, \mathrm{XXXV}$. Além disso, diante do princípio da voluntariedade das partes, elas não podem ser obrigadas a participar de processo restaurativo, devendo restar-lhes a opção pela justiça criminal. $\mathrm{Na}$ verdade, "com a propagação de sua forma de solucionar os conflitos, pretende-se atenuar o caos em que se encontra o sistema penal e, gradativamente, transformar o paradigma punitivo em restaurativo" (FERREIRA, 2011, p. 247).

A estratégia política é que, primeiramente, haja uma relação de "complementaridade" do modelo restaurativo com o modelo tradicional, para que aquele não entre, de cara, em conflito com este. "A partir daí, (a justiça restaurativa) inocula-se nas fissuras do sistema, em suas frestas, como um vírus, ou melhor, como um anticorpo à violência institucional, como um gérmen silencioso da mudança” (SCURO, 2008, p. 171).

Também, viu-se que, a partir da análise do programa do Núcleo Bandeirante realizado no Distrito Federal, a justiça restaurativa para adultos tem sido aplicada somente para os crimes de menor potencial ofensivo. Essa constatação é preocupante, pois, apesar de se reconhecer a importância da prática restaurativa para a recomposição de relações interpessoais, revela-se uma subestimação do papel inovador da justiça restaurativa. 
Portanto, é preciso superar os entraves que as medidas legais e o atual modelo de organização da justiça criminal brasileira constituem para um melhor desenvolvimento da justiça restaurativa no nosso país. A proposta é de usá-la como influência estabilizadora, instrumento de reafirmação do papel do Estado na aplicação de justiça, com integral respeito à dignidade de todas as pessoas envolvidas e ao seu direito de ver reconhecidos seus valores e pontos de vista (SCURO NETO, 2008, p.170).

Para a demonstração de que a ampliação da justiça restaurativa para os crimes ditos de maior potencial ofensivo é juridicamente possível e socialmente necessária, serão trabalhados os aspectos sociais e jurídicos e o risco da extensão do controle penal. Ressalta-se que esses argumentos não representam categorias distintas, mas, pelo contrário, dialogam entre si, sendo tal divisão apenas um critério metodológico.

\subsection{ASPECTOS SOCIAIS}

Renato de Vitto, ao analisar a lógica retributivista que predomina no sistema de justiça e no senso comum, bem como a cultura do medo difundida pela mídia, questiona se as instituições e a sociedade brasileira estariam preparadas para aceitar o modelo restaurativo. $\mathrm{O}$ autor afirma que tais considerações poderiam conduzir a uma conclusão negativa; no entanto, explica que as práticas restaurativas de qualidade, na verdade, como em outros países, funcionam como fio condutor para a desconstrução da barreira cultural que se opõe ao movimento restaurativo (2008, p.203).

Acompanhando esta crença, acredita-se que, além da ideia de que uma boa prática tem o poder de angariar adeptos ao movimento, o Brasil possui peculiaridades que demandam uma intervenção restaurativa. Primeiramente, como já resta claro, a seletividade, repressividade e desigualdade latente ao sistema penal pátrio produzem encarceramento exagerado, estigmatização e, por conseguinte, reincidência e descrédito perante a sociedade. Partindo da ideia de um sistema que gera desigualdades sociais, a 
justiça restaurativa, em um país como o nosso, torna-se indicação importante na medida em que ela pode significar um caminho para a redução daquelas. Também, ao evitar a pena de cárcere e ao priorizar a reintegração do ofensor na comunidade, o modelo restaurativo significa um duro golpe contra as fronteiras estigmatizantes que guarnecem o sistema penal. Ademais, em tempos em que a sociedade brasileira experimenta sentimentos de temor e insegurança, as práticas restaurativas podem representar um importante instrumento de implementação de uma cultura de paz e tolerância.

Nesse contexto, a violência característica da nossa sociedade constitui também fundamento para a inserção da justiça restaurativa no Brasil. Conforme Shuch (apud PALLAMOLLA, 2008, p. 196):

A violência social é tomada como um sintoma e expressão de relações não harmônicas e, sobretudo, desintegradas. O perigo da anomia, da não existência de valores que fundamentem uma existência social comum, é chave para instaurar a procura de novas práticas que substituam o modelo conflitivo. (...). Do risco, ou seja, do diagnóstico de uma violência constante e difusa, viria a necessidade de uma restauração de laços, de relacionamentos. (grifo nosso)

Todas essas características, de alguma forma, permitem que as instituições jurídicas e a sociedade, mesmo que de forma bem pontual, reflitam e aceitem o fato de que há outras formas de resolução de conflitos mais viáveis e eficazes. No que tange aos aspectos de eficiência, por mais que a lógica utilitarista não seja inerente ao movimento restaurativo, é impossível não abordar os ganhos que a justiça restaurativa poderia aportar ao nosso país, por exemplo, quanto aos índices de reincidência. Portanto, enfatizar resultados práticos pode ser uma boa estratégia para que a justiça restaurativa ganhe força no cenário brasileiro, visto que é estipulado, segundo os dados da CPI Carcerária, que o índice reincidência gire em torno de $70 \%$ a $85 \%$.

$\mathrm{Na}$ quase totalidade das pesquisas empíricas realizadas no mundo, acerca dos resultados restaurativos, demonstra-se a queda dos índices de reincidência dos ofensores que passaram pela justiça restaurativa. Zehr (2008, p.2) explica que não se pode afirmar 
que a justiça é plenamente eficaz para todos os ofensores, mas que, de acordo com o levantamento de pesquisas, o índice é reduzido em pelo menos um terço.

$\mathrm{Na}$ Austrália, foi realizado o estudo mais relevante acerca do índice de reincidência: jovens envolvidos apenas com crimes mais violentos reincidiram 38\% menos do que os jovens que praticaram o mesmo crime e foram submetidos à justiça penal. Ainda, um dado mais interessante foi que a alta queda de reincidência ocorreu apenas quanto aos crimes violentos, não sendo auferida, por exemplo, nos crimes de trânsito (SICA, 2008, p.175). Essa constatação vai ao encontro da ideia de que a justiça restaurativa é mais recomendada quanto menor for a necessidade de reintegração social do ofensor (JACCOUD, 2005, p.178).

Importante pontuar o exemplo da Colômbia como experiência bem-sucedida de aplicação da justiça restaurativa. Neste país, a justiça restaurativa foi reconhecida pela Constituição e pelo Código de Processo Penal Nacional. As práticas estão sendo avaliadas positivamente tanto para a sociedade quanto para o sistema jurídico como um todo, inclusive, tendo sido a elas atribuída a diminuição de $30 \%$ nas taxas de homicídios (ORTEGAL, 2006, p. 15). Esse exemplo é importante para a nossa realidade, visto que a Colômbia é um país latino-americano de com condições de desequilíbrio sócioeconômico semelhantes ao Brasil, permitindo confirmar a viabilidade da justiça restaurativa nos países periféricos.

Contudo, mesmo que os resultados em relação à reincidência não possam ser afirmados com total precisão, uma coisa é certa: não há qualquer evidência de que as práticas restaurativas aumentem a reincidência. Nesse sentindo, uma pesquisa empírica realizada em algumas regiões na Nova Zelândia concluiu dois pontos: os programas restaurativos não aumentaram as taxas de reincidência e, ainda, a satisfação dos participantes é enorme, visto ter aumentado também a sensação de justiça (numa região 95\% das pessoas disseram-se satisfeitas com a oportunidade do encontro; $83 \%$ ficaram satisfeitas com o acordo e $90 \%$ dos ofensores cumpriram o acordo) (SICA, 2008, p.175). 
Ainda, na Inglaterra, precisamente nas regiões de Coventry e Leeds, 90\% das vítimas disseram ter aceitado participar da mediação para poder expressar o impacto do delito em suas vidas, $73 \%$ considerou importante receber desculpas e apenas $16 \%$ mantiverem o medo de uma nova vitimização (SICA, 2008, p.175). Todos esses dados fortalecem a possibilidade real, e não fictícia, de que a justiça restaurativa aumenta o sentimento de segurança na comunidade, o que seria muito importante para a sociedade brasileira, já que paira na opinião pública uma sensação de desproteção e insegurança total. É uma oportunidade para que o poder público possa recuperar, tanto quanto possível, a credibilidade dos cidadãos.

Sob um panorama geral, Nancy Tello (2008, p. 209) aborda, conjuntamente, várias implicações sociais do sistema retributivo:

Nosso sistema judicial, baseado na ideia de delito como uma
ofensa ao Estado e violação à lei, não é satisfatório pra nada,
nada ganha e todos perdem, perde a vítima, por que depois de ter
sido lesionada, geralmente volta a ser vítima do sistema; perde o
agressor porque entra em um sistema que o estigmatiza, que não
o ajuda, só o afasta de todos e dele mesmo; perde o Estado,
porque investe grandes somas de dinheiro em um sistema
ineficiente e com isso a comunidade se enche de ressentimentos
pela inevitável sensação de injustiça, impunidade e insegurança.

Por fim, como explorado na abordagem conceitual da justiça restaurativa, esta se mostra uma definição flexível justamente para permitir que a operacionalização dos programas possa adequar-se às circunstâncias da comunidade em que serão inseridos. No Brasil, assim como noutros países latino-americanos, nada mais peculiar do que a conexão entre uma socialização deficiente, uma estrutura social desigual e a criminalidade de caráter patrimonial e econômico. Como visto, os crimes contra o patrimônio são responsáveis por $50 \%$ da nossa população carcerária. Assim, diante dessa característica nacional, e por se tratar de delitos nos quais facilmente as vítimas podem ser identificadas e provavelmente reparadas, é preciso também lançar um olhar restaurativo urgentemente sobre esses tipos penais. Como complemento, diversas pesquisas realizadas demonstram que, em crimes patrimoniais, as vítimas não registram o 
caso ou desistem do seu prosseguimento por saberem que o sistema não lhe oferecerá possibilidade de obter reparação (SICA, 2008, p. 184). Enfim, importa perceber que é inviável pensar "restaurativamente" o Brasil se não se considera a insuficiência das políticas públicas e sociais para promoção dos direitos básicos das pessoas mais desprovidas. Neste ponto, oportuna observação de Renato de Vitto (2008, p.203):

\begin{abstract}
A frustração e descrença de que o Estado pode fazer frente aos problemas sociais que, por sua vez, estão diretamente relacionadas com a prática de crimes contra o patrimônio e de mercancia ilegal de entorpecentes propicia as condições necessárias para a aceitação e crença na adoção de soluções imediatistas voltadas à redução da criminalidade.
\end{abstract}

Assim, como alerta Renato Sócrates (2005, p.34), "precisamos construir uma justiça restaurativa latino-americana, considerando que nossa criminalidade retrata mais uma reação social, inclusive organizada, a uma ordem injusta, cruel, violenta e, por que não, também criminosa".

Portanto, em um sistema de justiça penal, como o brasileiro, que simplesmente pune os transgressores e desconsidera as vítimas, não levando em consideração as necessidades emocionais e sociais daquelas afetadas por um crime, a justiça restaurativa faz-se importante não apenas reduzir a criminalidade, mas também pra reduzir o impacto dos crimes sobre os cidadãos. Essa capacidade transformadora da justiça restaurativa expressada através de seus valores é o ponto chave para a obtenção e manutenção de uma sociedade brasileira menos violenta e excludente e mais saudável e tolerante. 


\subsection{ASPECTOS JURÍDICOS}

Sabe-se que no atual ordenamento jurídico brasileiro, não existe previsão legal da Justiça Restaurativa $^{62}$. No entanto, o Brasil constitui-se um Estado Democrático Brasileiro e possui uma Constituição Federal de forte caráter principiológico.

Renato de Vitto pontua que, cronologicamente, a partir do início da década de 90, a legislação brasileira passou a incorporar, ainda que de forma tímida, o modelo consensual como forma de reação estatal ao delito o que abriu espaço para a instauração dos procedimentos restaurativos no país (2008, p.209). Como visto nas fundamentações utilizadas pelos magistrados do programa do Núcleo Bandeirante, os dispositivos 98, I, da Constituição Federal, artigos da Lei n $9.099 / 95$ e artigo $3^{\circ}$ do Código de Processo Penal têm abalizado os encaminhamentos de casos aos processos restaurativos.

No entanto, quando se objetiva mudanças profundas no sistema de justiça, é mais importante a atitude dos operadores envolvidos do que a mera previsão legal. Um jurista sempre pode estar à frente do tempo da lei. Acredita-se, então, que o maior entrave ao avanço da justiça restaurativa, no contexto brasileiro, é a própria lógica punitiva que predomina no sistema. Como diz Zehr: "o motivo de tantos de nossos fracassos é a lente através da qual enxergamos o crime e a justiça, pois essa lente é uma construção da realidade bastante específica, ela é um paradigma. Mas este não é o único paradigma possível" (ZEHR, 2008, p. 90).

Portanto, mesmo diante de um sistema ainda muito fechado à aplicação da justiça restaurativa aos crimes de maior potencial ofensivo, pensa-se que o mais interessante, para o sistema brasileiro, no momento, enquanto não se mudam as lentes e nem as leis ${ }^{63}$,

\footnotetext{
62 Ressalta-se que há atualmente em tramitação no Congresso Nacional Projeto de Lei ${ }^{\circ} 7.006 / 06$ cujo objetivo é a introdução da previsão legais da Justiça Restaurativa no ordenamento brasileiro. O projeto foi encaminhado através da Sugestão Legislativa no 099/2005 do Instituto Brasileiro de Direito Comparado.

${ }^{63}$ Cumpre ressaltar que eventual positivação da Justiça Restaurativa no ordenamento brasileiro não asseguraria práticas de qualidades. No entanto, diante do apego dos juristas brasileiros à legalidade, tal legalização será importante se, e somente se, não adotar critérios extremamente restritivos quanto à
} 
é que a justiça restaurativa seja trabalhada como uma forma diferente de auferir responsabilidade penal à pessoa, através da qual se pode chegar a diversas respostas, desde evitar o processo penal, atenuar ou eximir a pena, ou ainda reduzir a duração da pena privativa de liberdade, diferentemente, portanto, do processo penal que está invariavelmente adstrito a uma decisão que deve condenar ou absolver o réu. Assim, pode-se ter uma experiência bastante exitosa na justiça penal de adultos autores de delitos mais graves. Relembre-se novamente do caso analisado, em que a juíza versada nos princípios da justiça restaurativa construiu arranjos legais que permitiram a atenuação da pena do ofensor. Nesse contexto, "não se trata de relativizar a importância da técnica jurídica na construção da justiça restaurativa no Brasil, mas de possibilitar que o aspecto jurídico se faça presente, sem ignorar outras abordagens sobre a realidade que contribuem para a ressignificação, por exemplo, das relações sociais e seus conflitos (PENIDO, 2006, p.567).

Nesse sentido, como exemplo de experiência restaurativa que seria relevante para o atual sistema brasileiro, tem-se a Espanha, posto que também se apresenta como um modelo de justiça mais fechado. No país, os casos que passaram pela justiça restaurativa são trabalhados principalmente como atenuantes, genéricas ou específicas, da pena. $\mathrm{Na}$ justiça catalã, a mediação restaurativa pode acontecer nos casos de roubos, estelionatos, apropriações indébitas e danos materiais, desde que o ofensor não seja delinquente habitual $^{64}$ (PALLAMOLLA, 2008, p.197).

Ainda, um dos grandes pontos jurídicos que a justiça restaurativa levanta é o acesso à justiça. Morris (2005, p. 455) afirma que a legitimidade da justiça restaurativa consiste no fato de ser uma forma mais justa de tratar infratores e vítimas. Aqui, pode-se acrescentar que as práticas restaurativas oportunizam o direito não apenas a um processo justo, mas também de qualidade, eficaz para a resolução do conflito. Portanto, antes dos

possibilidade de derivação e aos procedimentos. Pois, repita-se, a abertura do tema é necessária para que possa se adequar a cada contexto social.

${ }^{64}$ De acordo com o artigo 94 do Código Penal da Espanha, réus habituais são os que cometeram três ou mais delitos dos compreendidos num mesmo Capítulo, em um prazo não superior a cinco anos, e tenham sido condenados por isso. Tradução livre. 
objetivos práticos que busca realizar, a justiça restaurativa representa um direito de acesso à justiça:

Assim, frente à mencionada crise de legitimidade do sistema penal, o crescimento da violência na sociedade brasileira e a crise da administração da justiça, as formas alternativas de administração de conflitos se multiplicam e procuram aumentar o acesso à justiça e, desta forma, promover a equidade econômica e social de modo a fortalecer a democracia. (PALLAMOLLA, 2009, p. 149)

Ainda, além dos princípios ${ }^{65}$ consagrados do direito penal, basta perceber que, numa Constituição em que se encontra como fundamento a dignidade da pessoa humana (artigo $1^{\circ}, \mathrm{III}, \mathrm{CF}$ ) e como objetivos a construção de uma sociedade livre, justa e solidária e do bem de todos sem preconceitos (artigo $2^{\circ}$, I, II, CF), isso por si só, permitenos concluir que não se promove esses valores numa sociedade sem trabalhar o fenômeno criminal e sem objetivar, além de outras questões, a contenção da frente repressiva do sistema penal.

Portanto, no Brasil, abre-se a possibilidade de a justiça restaurativa funcionar como oportunidade de acesso a uma justiça criminal participativa que visa operar a real transformação e que abre caminho para uma nova promoção dos direitos humanos, da dignidade, cidadania, inclusão e paz social.

\subsection{O RISCO DA EXTENSÃO DA REDE DE CONTROLE PENAL}

Com a sanção da Lei $n^{\circ} 9.009 / 95$, é inegável que o legislador brasileiro avançou no tocante à incorporação de modelos consensuais de reação estatal ao delito, através dos institutos despenalizadores, como a transação penal, a composição de danos e a suspensão condicional do processo.

\footnotetext{
65 Por exemplo, conforme os princípios abordados por Nilo Batista (2001), tem-se os seguintes: da intervenção mínima, da lesividade e da humanidade.
} 
No entanto, como observa Leonardo Sica (2007, p. 182-183), ao longo da atuação prática dos Juizados Especiais Criminais, observou-se um efeito contrário: a institucionalização das práticas de mediação penal resultou na expansão das redes de controle (efeito net-widening). Isso porque, por exemplo, os Juizados repristinaram uma série de contravenções penais e delitos menores que, antes da edição da referida lei, já tinham perdido a relevância penal. O autor explica, ainda, que essa expansão do controle penal é um efeito colateral da sobreposição de duas lógicas distintas: a punitiva e a consensual.

Em relação à justiça restaurativa, os teóricos apontam que o risco de se incorrer na expansão da rede tem pertinência com os tipos de delitos nos quais ela é aplicada. Conforme anota Mylène Jaccoud (2005, p.179), a preocupação é que a "justiça restaurativa seja aplicada a situações que, sem ela, não teriam sido tratadas pelo sistema penal. (...). Assim, em vez de desafogar os tribunais, a justiça restaurativa corre o risco de não apenas sobrecarregar o sistema, mas também de contribuir para aumentar o controle penal."

Foi nesse sentido que, durante o Fórum Europeu para Mediação Vítima-Ofensor e Justiça Restaurativa de 2002, destacou-se que a tendência é que o modelo restaurativo não seja aplicado para os crimes menores, que possuem pouca relevância penal. Para evitar essa situação, por exemplo, a Áustria estabeleceu que o processo restaurativo só deve ser utilizado para delitos de gravidade média (para adultos, com pena prevista de até 5 anos), proibindo-se os casos bagatelares (SICA, 2008, p. 184).

Guadalupe Sanzberro (apud SICA, 2008, p.184), autora espanhola, afirma que é possível evitar o efeito de ampliação da rede de controle, desde que não se estimule a justiça restaurativa em casos de escassa relevância, ante os quais se decidiria pelo arquivamento do feito, e propõe que a mediação seja utilizada em casos de gravidade média e, ainda, que a reincidência não seja um fator que afaste a possibilidade de uma solução consensual. Quanto a este último aspecto, percebe-se que seria de suma 
importância no contexto brasileiro, já que a reincidência, aqui, tem um tratamento extremamente excludente.

Alisson Morris (2005, p.446), rebatendo à crítica de que a justiça restaurativa pode aumentar o controle penal, afirma que, na Nova Zelândia, ela não é dirigida a crimes desimportantes, mas sim, quanto aos adultos, a crimes relativamente sérios. A autora exemplifica como casos que passam cotidianamente pelos processos restaurativos: os roubos qualificados, ameaças de morte, mortes causadas por acidentes de trânsito, dano doloso e arrombamento.

Confrontando essas considerações com a realidade prática brasileira, percebe-se que os riscos quanto à extensão da rede de controle são presentes e concretos. Isso porque o projeto de maior notoriedade para delitos de adultos, o Programa do Núcleo Bandeirante, está adstrito a crimes de menor potencial ofensivo. Como atestado na pesquisa realizada neste trabalho, foram encaminhados, por exemplo, tipos penais de crueldade contra animais, omissão de cautela na guarda ou condução de animais e alteração de limites, casos que, claramente, não apresentam nenhuma relevância penal.

Juliana Benedetti e Mariana Raupp (2007,p. 4-5) , ao analisarem a flexibilidade conceitual da justiça restaurativa, destacam que, na verdade, o que mais devem ser enfatizados são os objetivos a que ela se propõe. Assim, sob a finalidade institucional, a justiça restaurativa representaria uma forma de aprimoramento institucional dos órgãos estatais na tarefa de persecução do crime e do ato infracional. Por outro lado, sob uma finalidade político-criminal, a justiça restaurativa representa um mecanismo de transformação, mais amplo, do tratamento dado ao fenômeno criminal.

É partindo dessas duas perspectivas, que se pode, então, concluir que, na práxis, o Programa realizado no Núcleo Bandeirante tem assumido a justiça restaurativa sob um objetivo institucional na medida em que tem se posicionado como uma adição, ou seja, um complemento ao funcionamento do Poder Judiciário. Vale reiterar que, como já dito aqui, essa relação de complemento não pode ser de toda negada, porém o que se quer 
afirmar é que a postura do programa em manter-se restrito aos casos de bagatela pode denotar que não possui um objetivo mais amplo de transformação do próprio sistema.

Então, para que não se incorra no problema da extensão da rede, ou seja, para que se possa, de verdade, reduzir o controle penal formal, é preciso que o Brasil compre a meta restaurativa como verdadeira política criminal. E, sabendo-se do contexto de crise de legitimidade da justiça penal brasileira, essa política deve ser caracterizada pela tolerância, evitando-se assim as reprimendas punitivas excessivas através da participação e envolvimento comunitário. Apenas assumindo tal postura é que se torna possível vislumbrar, mesmo que a longuíssimo prazo, uma real mudança do paradigma punitivo para o restaurativo.

Portanto, acredita-se ser possível que o programa do Núcleo Bandeirante, bem como novos projetos que venham a ser criados, permaneça atuando em certos casos de menor potencial ofensivo que importe um mínimo de relevância penal, principalmente se suas circunstâncias concretas demonstrarem que uma solução não-consensual afetaria profundamente relações interpessoais entre os envolvidos e que, ainda, poderia iniciar um ciclo conflituoso mais grave. Por outro lado, entende-se que se a justiça restaurativa for além, como verdadeira política criminal, estenderá suas qualidades restauradoras e transformativas aos crimes de médio e médio-alto potencial ofensivo, contribuindo, assim, para o encolhimento do sistema penal repressivo, relegando este a uma ultima ratio. O desafio está lançado. Diante do caso relatado, percebe-se que a justiça restaurativa deu um grande passo adiante, demonstrando que novas possibilidades são sempre possíveis. 


\section{CONCLUSÃO}

Todo o movimento de contestação das instituições repressivas - labelling approach, Criminologia Crítica e Abolicionismo nutriram a reflexão para o desenvolvimento de um movimento que recomenda o recurso para uma justiça diferente, humanista e não punitiva. A Criminologia da reação social criou as bases necessárias para um posicionamento crítico perante o Direito Penal e à atuação do sistema penal. $\mathrm{O}$ Abolicionismo, ao propor a reapropriação dos conflitos pelos ofensores e vítimas, permitindo, assim, que a comunidade recuperasse a capacidade de solucionar os conflitos penais, e a Vitimologia, ao revelar a incapacidade do sistema penal para atender as necessidades das vítimas, construíram ideias significativas para as propostas da justiça restaurativa.

Perante da incapacidade do sistema penal brasileiro em não cumprir com a prevenção do crime e a ressocialização do ofensor, verifica-se a falibilidade e falsidade do seu discurso jurídico- penal quanto às funções que prega. Ainda, diante do aumento constante da violência, da fomentação de uma cultura do medo, da insatisfação dos cidadãos perante a justiça penal e da trágica realidade prisional brasileira, é que a justiça restaurativa, a partir de princípios diferenciados, se apresenta como uma possibilidade na tarefa de praticar uma justiça penal mais equânime, mais humana e racional.

As tentativas brasileiras para amenizar a situação, como as alterações trazidas pela legislação processual penal, principalmente quanto à instituição das penas alternativas e aos Juizados Especiais Criminais, não lograram êxito para a redução da criminalidade e nem do encarceramento em massa. Diante desse panorama brasileiro, fortalece-se a ideia de que a repressão característica do sistema penal tradicional não é a única opção de controle do crime. 
Foi partindo dessas considerações, que o Ministério da Justiça do Brasil, em parceria com outras instituições, iniciou a implantação de projetos-piloto de justiça restaurativa no contexto nacional. No entanto, apesar de todo o avanço dado pela iniciativa, percebe-se que a justiça restaurativa ainda não pôde desenvolver todo o seu potencial principiológico e programático construído a partir dos valores e objetivos que prega.

Isso porque, como visto, a implementação do modelo restaurativo no cenário brasileiro, em relação à justiça criminal para adultos, tem se limitado aos crimes de menor potencial ofensivo, o que ficou demonstrado com a prática do Programa de Justiça Restaurativa no Núcleo Bandeirante-DF, pois vinculado ao âmbito de aplicação da Lei $n^{\circ}$ 9.099/95. Tal limitação levanta várias preocupações, como o risco de extensão do controle penal e a perda de todo o potencial transformador proposto pelo modelo restaurativo.

Assim é que, ao se considerar todos os ganhos permitidos com as práticas restaurativas, tais como o acesso à justiça, inclusão e reparação do dano causado às vítimas, a responsabilização e não-estigmatização do ofensor, a participação comunitária, satisfação dos envolvidos e redução dos índices de reincidência e prisionalização, percebe-se que a justiça restaurativa tem muito a contribuir com a justiça brasileira. São vários os argumentos sociais e jurídicos que justificam a derivação aos crimes de maior potencial ofensivo. Portanto, a sociedade brasileira não apenas está apta para adotar práticas restaurativas como também necessita delas para que seja propiciada mais justiça, participação, paz e democracia aos seus cidadãos.

Não se pode olvidar, no entanto, que o sistema penal nacional ainda se apresenta muito apegado à lógica repressiva para crimes de maior potencial ofensivo. Contudo, viuse que, a partir do caso apresentado, é possível que se abra mais portas em que a frente restaurativa possa atuar nesses crimes. O programa do Núcleo Bandeirante deu o primeiro passo na largada da construção de uma justiça restaurativa que seja aplicada positivamente no contexto brasileiro. E se isso foi possível é porque o nosso ordenamento 
jurídico e as nossas peculiaridades sociais permitem que ampliemos o horizonte de aplicação do modelo restaurativo. Nossa Constituição Federal permite interpretações condizentes com o projeto restaurativo, na medida em que erige a dignidade da pessoa humana, o bem social de todos e a justiça social como princípios básicos de uma nação. Não se pode falar em uma nação justa se os seus conflitos penais são administrados com violência, repressão, desproporção e desigualdade.

Portanto, diante da configuração atual da justiça restaurativa no Brasil, esta funcionando como complemento do sistema de justiça tradicional, defende-se que é possível uma convivência entre ambos. No entanto, é preciso que a justiça restaurativa vá além do sistema tradicional, enriquecendo-o, transformando-o e quebrando suas barreiras. O projeto brasileiro analisado demonstrou, através do caso apresentado, ser possível a ampliação da justiça restaurativa para os crimes de maior potencial ofensivo e, em razão da visibilidade deste programa, acredita-se que ele pode, cada vez mais, progredir e fincar boas influências nesse sentido. Ainda, visto ser um projeto que atende aos valores restaurativos, pode constituir-se como um grande exemplo para atitudes corajosas e transformadoras neste país.

Tendo em vista tudo o que foi exposto neste trabalho, principalmente acerca das experiências estrangeiras, pode-se concluir que está na hora de se avançar no Brasil acerca das intervenções restaurativas. Estas devem ser ampliadas para os crimes de maior potencial ofensivo a fim de que seja buscado o seu potencial de assegurar um acesso à justiça, à democracia participativa, bem como restaurador de relações, transformador de vítimas, ofensores e da comunidade. Enfim, torna-se claro que o momento é propício para estas mudanças no sistema penal brasileiro. A justiça restaurativa se apresenta como um modelo viável, na verdade, necessário ao contexto nacional. Assim, suas propostas devem ser acolhidas, discutidas e, sobretudo, ampliadas. 


\section{REFERÊNCIAS}

AMORIM, Jan Yuri Figueireido de. Conflitos armados e vítimas: da necessidade de se preocupar com elas para uma maior efetividade da proteção dos direitos humanos. 2008. 101f. Dissertação (Mestrado em Direito) - Universidade de Brasília.

ANDRADE, Vera Regina. Do paradigma etiológico ao paradigma da reação social: mudança e permanência de paradigmas criminológicos na ciência e no senso comum. Revista Brasileira de Ciências Criminais. São Paulo: Revista dos Tribunais, 1996, n.14, p. 276-287.

Minimalismos e Abolicionismos: a crise do sistema penal entre a deslegitimação e expansão. In: Revista Ultima Ratio. Rio de Janeiro: Lumen Juris, ano I, n. 1, p.397-417.

ANITUA, Gabriel Ignacio. O positivismo e a criminologia científica. In: ANITUA, Gabriel Ignacio. Histórias dos pensamentos criminológicos. Rio de Janeiro: Revan, 2008. Capítulo V, p. 297- 404.

As teorias da reação social, teorias do conflito, o marxismo e o pensamento crítico em relação à questão criminal. In: ANITUA, Gabriel Ignacio. Histórias dos pensamentos criminológicos. Rio de Janeiro: Revan, 2008. Capítulo VIII, p. 569- 641.

Pensamentos criminológicos de finais do século XX: a chamada criminologia crítica (origens, tendências, presenças). In: ANITUA, Gabriel Ignacio. Histórias dos pensamentos criminológicos. Rio de Janeiro: Revan, 2008. Capítulo IX, p. 657- 742 .

AZEVEDO, André Gomma de. O componente de Mediação Vítima-ofensor na Justiça Restaurativa: uma breve apresentação de uma inovação espistemológica na autocomposição penal. In: SLAKMON, Catherine; DE VITTO, Renato Pinto de; 
PINTO, Renato Sócrates Gomes (orgs.). Justiça Restaurativa: coletânea de artigos.Brasília: Ministério da Justiça, 2005, p.135-161.

BARATTA, Alessandro. Criminologia crítica e crítica do direito penal: introdução à Sociologia do Direito Penal. Tradução por Juarez Cirino dos Santos. $3^{a}$ ed., Rio de Janeiro: Revan, 2002.

BASTOS, Márcio Thomaz. Apresentação. In: SLAKMON, Catherine; MACHADO, Maíra Rocha; BOTTINI, Pierpaolo Cruz (orgs.). Novas direções na governança da justiça e da segurança. Brasília: Ministério da Justiça, 2006, p.15.

BATISTA, Nilo. Introdução crítica ao Direito Penal. 4ª ed., Rio de Janeiro: Revan, 2001.

BECKER, Howard S. Outsiders: estudos da sociologia do desvio. Tradução por Maria Luiza X. de A. Borges. Rio de Janeiro: Zahar, 2008, p. 1-66.

BENEDETTI, Juliana Cardoso. Tão próximos, tão distantes: a justiça restaurativa entre a comunidade e sociedade. 2009. 143f. Dissertação (Mestrado em Direito) Universidade de São de Paulo.

A justiça restaurativa de John Braithwaite: vergonha reintegrativa e regulação responsiva. In: Revista DireitoGV, v. 1, n. 21, p. 209-216, jun./dez., 2005.

A justiça restaurativa em face da criminologia da reação social. In: SLAKMON, Catherine; MACHADO, Maíra Rocha; BOTTINI, Pierpaolo Cruz (orgs.). Novas direções na governança da justiça e da segurança. Brasília: Ministério da Justiça, 2006, p. 491-520.

BENEDETTI, Juliana; RAUPP, Mariana. A implementação da Justiça Restaurativa no Brasil: uma avaliação dos programas de justiça restaurativa de São Caetano do Sul, Brasília e Porto Alegre. In: Revista Ultima Ratio. Rio de Janeiro: Lumen Juris, ano I, n. 1, p.3-36. 
BRAITHWAITE, Jonh. Emancipação e Esperança. In: SLAKMON, Catherine; MACHADO, Maíra Rocha; BOTTINI, Pierpaolo Cruz (orgs.). Novas direções na governança da justiça e da segurança. Brasília: Ministério da Justiça, 2006, p. 389-409.

CONDE, Francisco Muñoz; HASSEMER, Winfried. Introdução à Criminologia. Tradução por Cíntia Toledo Miranda Chaves. 2a ed., Rio de Janeiro: Lumen Juris, 2011.

COSTA, Helena Maria; MOURA, Marília Lobão Ribeiro de Moura. A eficácia da Justiça Restaurativa nas Varas Criminais. In: GALVÃO; Ivânia Ghesti; ROQUE, Elizângela Caldas Barroca (orgs.). Aplicação da lei em uma perspectiva interprofissional: Direito, Psicologia, Psiquiatria, Serviço Social e Ciências Sociais na prática Jurisdicional. Rio de Janeiro: Lumen Juris, 2010.

DE VITTO, Renato de Campos. Reflexões sobre a compatibilidade do modelo restaurativo com o sistema de justiça brasileiro. In: Revista IOB de Direito Penal e Processo Penal, Porto Alegre, vol.9, n.49, abr./maio 2008, pp. 199-209.

Justiça Criminal, Justiça Restaurativa e Direitos Humanos. Justiça Restaurativa é possível no Brasil? In: SLAKMON, Catherine; DE VITTO, Renato Pinto de; PINTO, Renato Sócrates Gomes (orgs.). Justiça Restaurativa: coletânea de artigos.Brasília: Ministério da Justiça, 2005, p. 41-51.

FERREIRA, Carolina Costa Ferreira. As ilusões do paradigma punitivo e as novas perspectivas de solução de conflitos: a justiça restaurativa como caminho possível à crise do sistema penal brasileiro. Revista de Estudos Jurídicos UNESP, v. 19, p. 241$252,2011$.

FIELD, Rachel. Encontro Restaurativo Vítima-Infrator: questões referentes ao desequilíbrio de poder para participantes jovens do sexo feminino. In: SLAKMON, Catherine; DE VITTO, Renato Pinto de; PINTO, Renato Sócrates Gomes (orgs.). Justiça Restaurativa: coletânea de artigos.Brasília: Ministério da Justiça, 2005, p. 385-412. 
FOUCAULT, Michel. Vigiar e punir. História da violência nas prisões. Tradução por Raquel Ramalhete. 34ª ed., Rio de Janeiro: Vozes, 2007.

GOMES PINTO, Renato Sócrates. Justiça Restaurativa é possível no Brasil? In: SLAKMON, Catherine; DE VITTO, Renato Pinto de; PINTO, Renato Sócrates Gomes (orgs.). Justiça Restaurativa: coletânea de artigos.Brasília: Ministério da Justiça, 2005, p. 19- 39.

Justiça Restaurativa: um novo caminho? In: Revista IOB de Direito Penal e Processo Penal, Porto Alegre, vol.8, n.47, dez. 2007/jan. 2008, pp. 190-202.

GROSNER, Marina Quezado. A seletividade do sistema penal na Jurisprudência do Superior Tribunal de Justiça. São Paulo: IBCCrim, 2008.

ILANUD. Cárcere e justiça penal na América Latina e Caribe: como implementar o modelo de direitos e obrigações das Nações Unidas. Instituto Latino-Americano das Nações Unidas para a Prevenção do Delito e Tratamento do Delinquente, ILANUD. Brasília: Ministério da Justiça, 2008. Também disponível na internet: www.ilanud.or.cr.

JACCOUD, Mylène. Princípios, tendências e procedimentos que cerca a justiça restaurativa. In: SLAKMON, Catherine; DE VITTO, Renato Pinto de; PINTO, Renato Sócrates Gomes (orgs.). Justiça Restaurativa: coletânea de artigos.Brasília: Ministério da Justiça, 2005, p. 163- 188.

KOSOVSKI, Ester. Vitimologia, Direitos Humanos e Justiça Restaurativa. In: Revista IOB de direito penal e processo penal, ano VII, n. 48, p.146-162, fev./mar.2008.

LEAL, César Barros. A Justiça Restaurativa: uma visão global e sua aplicação nas prisões. In: Revista Magister de Direito Penal e Processual Penal, ano VII, $n^{\circ} 38$, out./nov, 2010, p.37-47.

Manual de Mediação Judicial.André Goma de Azevedo (org.). Brasília: Ministério da Justiça e Programa das Nações Unidas para o Desenvolvimento - PNUD, 2009. 
MARSHALL, Chris; BOYACK, Jim; BOWEN, Helen. Como a justiça Restaurativa assegura a boa prática: uma abordagem baseada em valores. In: SLAKMON, Catherine; DE VITTO, Renato Pinto de; PINTO, Renato Sócrates Gomes (orgs.). Justiça Restaurativa: coletânea de artigos.Brasília: Ministério da Justiça, 2005, p. 267- 277.

MCCOLD; Paul; WACHTEL; Ted. Em busca de um paradigma: uma teoria de Justiça Restaurativa. In: Restorative Practices, EFORUM, agosto, 2003, p.3. Também disponível em: www.restorativepractices.org. Acesso em 15/04/2011.

MORRIS, Alisson. Criticando os críticos: uma breve resposta aos críticos da Justiça Restaurativa. In: SLAKMON, Catherine; DE VITTO, Renato Pinto de; PINTO, Renato Sócrates Gomes (orgs.). Justiça Restaurativa: coletânea de artigos.Brasília: Ministério da Justiça, 2005, p. 439- 472.

OLIVEIRA, Salete. Conversas com um abolicionista do sistema penal (parte 2): Entrevista com Louk Hulsman. In: Verve, $n^{\circ} 2,2002$, p. 186-209.

ORTEGAL, Leonardo Rodrigues de Oliveira. Justiça Restaurativa: uma via para a humanização da justiça. 2006. 61f. Trabalho de Conclusão de Curso (Graduação em Serviço Social) - Universidade de Brasília.

PALLAMOLLA, Raffaella da Porciuncula. Justiça Restaurativa: da teoria à prática. São Paulo: IBCCRIM, 2009.

Breves apontamentos acerca da relação entre justiça restaurativa e o sistema de justiça criminal brasileiro. Artigo Publicado no Boletim IBCCRIM n 206. Janeiro, 2010.

Justiça Restaurativa: legislação e experiências espanholas. In: Revista IOB de Direito Penal e Processual Penal, Porto Alegre, ano IX, n. 51, ago./set. 2008, pp. 177-197. 
PAVARINI, Massimo. Entrevista concedida à Folha de São Paulo em 31/08/2009. Disponível em http://profmatzenbacher.blogspot.com/2009/09/entrevista-prof-massimopavarini.html. Acesso em 26/04/2011.

PENSAR A JUSTIÇA RESTAURATIVA NO BRASIL. Anais da Audiência Pública realizada na Câmara dos Deputados. Brasília: Centro de Documentação e Informação, 2007.

PENIDO, Egberto de Almeida. O valor do sagrado e da ação não-violenta nas dinâmicas restaurativas. In: SLAKMON, Catherine; MACHADO, Maíra Rocha; BOTTINI, Pierpaolo Cruz (orgs.). Novas direções na governança da justiça e da segurança. Brasília: Ministério da Justiça, 2006, p. 567-581.

PIJOAN, Elena Larrauri. Tendências atuais da justiça restaurativa. In: Revista IOB de direito penal e processo penal, v.9, n.54, p.166-196, fev./mar.2009.

RELATÓRIO FINAL. Comissão Parlamentar de Inquérito do Sistema Carcerário. Brasília: Câmara dos Deputados, julho, 2008, 579 p.

SCURO NETO, Pedro. Chances e entraves para a justiça restaurativa na América Latina. In: SLAKMON, Catherine; DE VITTO, Renato Pinto de; PINTO, Renato Sócrates Gomes (orgs.). Justiça Restaurativa: coletânea de artigos.Brasília: Ministério da Justiça, 2005, p. 227-244.

O enigma da esfinge: uma década de Justiça Restaurativa no Brasil. In:

Revista IOB de Direito Penal e Processo Penal, vol.8, ano VII, n. 48, p.163-184, fev./mar.2008.

SHECARIA, Sérgio Salomão. Criminologia. $3^{a}$ ed., São Paulo: Revista dos Tribunais, 2011.

SICA, Leonardo. Bases para o modelo brasileiro de justiça restaurativa. In: SLAKMON, Catherine; MACHADO, Maíra Rocha; BOTTINI, Pierpaolo Cruz (orgs.). Novas direções na governança da justiça e da segurança. Brasília: Ministério da Justiça, 2006, p. 455-490. 
Justiça Restaurativa: críticas e contra-críticas. In: Revista IOB de Direito Penal e Processo Penal, vol.8, n. 47, p.158-198, dez.2007/jan.2008.

SOUSA, Asiel Henrique de. Projeto Justiça Restaurativa. Disponível em http://www.premioinnovare.com.br/praticas/projeto-justica-restaurativa-88/print/. Acesso em 19/04/2011.

SPAGNA, Laiza Mara Neves. As Novas Tecnologias de Administração de Conflitos e o Reconhecimento das Violências Interpessoais: O Caso da Justiça Restaurativa no Distrito Federal. Trabalho proposto para apresentação no I ENADIR - Encontro Nacional de Antropologia do Direito. Universidade de São Paulo - 20 e 21 de agosto de 2009.

TELLO, Nancy Flemming. A Justiça Restaurativa: um programa integral de atenção e prevenção ao delito. In: Revista IOB de Direito Penal e Processo Penal, São Paulo, ano IX, n. 52, out./nov. 2008, pp. 199-209.

VILAS-BÔAS, Renata Malta. Metodologia de Pesquisa Jurídica. Brasília: Fortium Editora, 2006.

WALGRAVE, Lode. Imposição da restauração no lugar da dor:reflexões sobre a reação judicial ao crime. In: SLAKMON, Catherine; MACHADO, Maíra Rocha; BOTTINI, Pierpaolo Cruz (orgs.). Novas direções na governança da justiça e da segurança. Brasília: Ministério da Justiça, 2006, p. 433-453.

ZAFFARONI, Eugenio Raúl. Em busca das penas perdidas: a perda de legitimidade do sistema penal. Tradução por Vânia Romano Pedrosa e Amir Lopez da Conceição. $5^{\text {a }}$ ed., Rio de Janeiro: Revan, 2001.

; PIERANGELI, José Henrique. Manual de direito penal brasileiro, volume 1: parte geral. $7^{\mathrm{a}}$ ed., São Paulo: Revista dos Tribunais, 2007.

ZAGALLO, Ricardo Luiz. A justiça restaurativa no Brasil: entre a utopia e a realidade. 2010. 101f. Dissertação (Mestrado em Direito) - Universidade de Brasília. 
ZEHR, Howard. Trocando as lentes: um novo foco sobre o crime e a justiça. Tradução por Tônia Van Acker. São Paulo: Palas Athena, 2008.

Avaliação e princípios da justiça restaurativa. In: SLAKMON, Catherine; MACHADO, Maíra Rocha; BOTTINI, Pierpaolo Cruz (orgs.). Novas direções na governança da justiça e da segurança. Brasília: Ministério da Justiça, 2006, p. 411417. 


\section{APÊNDICE}

\section{ENTREVISTA REALIZADA COM OS FACILITADORES DO PROGRAMA DE JUSTIÇA RESTAURATIVA DOS JUIZADOS ESPECIAIS CRIMINAIS DO NÚCLEO BANDEIRANTE (1º SEMESTRE/2011)}

\section{1) Como se deu a implantação do projeto e qual a sua atual situação institucional em relação ao TJDFT?}

Para responder esta pergunta, foi fornecido material institucional do programa que nos permitiu observar as recentes alterações. Assim, atualmente, verificou-se que, com a Resolução $\mathrm{n}^{\circ} 5$ de 19/05/2011, foram modificadas as configurações formais do funcionamento da justiça restaurativa no Núcleo, passando da denominação de projeto para ser reconhecido como um programa institucional do TJDFT.

\section{2) Qual a composição atual da equipe que compõe o projeto?}

Quanto à coordenação do programa, o Dr. Roberval Casemiro Belinati, desembargador do TJDFT, é o coordenador geral do programa. Enquanto os juízes Dr. Asiel Henrique De Souza e Dra. Léa Martins Sales são os coordenadores do programa no Núcleo Bandeirante. Ainda, aqui no Núcleo, temos a psicóloga Dra. Simone Republicano como supervisora.

A estrutura do programa consta, hoje, com três servidores e duas estagiárias. Somos um bacharel em direito e duas psicólogas, exercendo a função de facilitadores e temos duas estagiárias, uma de psicologia e a outra de administração de empresas, que, dentre outras funções, organizam os dados estatísticos do projeto. Somos dois servidores requisitados, um da TERRACAP e outro da Secretaria de Estado de Educação do Distrito Federal, e a supervisora do projeto é servidora concursada do TJDFT.

3) Quais são os critérios para o encaminhamentos dos casos ao programa de justiça restaurativa? 
$\mathrm{Na}$ audiência preliminar, na qual estão presentes o juiz e o promotor, são utilizados critérios para o encaminhamento sob dois aspectos: um objetivo, a previsão legal de pena não superior a dois anos, e subjetivo, que é preferencialmente a convivência próxima entre as partes e as circunstâncias do caso. Cabe ao juiz, com a devida anuência do promotor, determinar o encaminhamento ao núcleo. A consequência jurídica desse encaminhamento é a suspensão do processo penal por, geralmente, 90 a 120 dias. Daí, se nesse período, não houver o acordo restaurativo entre as partes, reinicia-se o processo penal tradicional. Esse período de suspensão pode ser aumentado e também, durante a suspensão, a vítima não está impedida de representar contra o ofensor novamente, mesmo que tenha iniciado o processo restaurativo aqui.

As partes devem aceitar vir para o programa. A voluntariedade das partes é fundamental para que os acordos possam ter sustentação, por isso ela deve ser bastante preservada. Caso contrário, se as partes não participarem voluntariamente, principalmente o ofensor, corre o risco de o acordo não ser cumprido ou, ainda, pode até ser cumprido, mas não altera e nem restaura efetivamente as relações.

\section{4) Depois do encaminhamento, como acontece o início dos procedimentos restaurativos? Qual a técnicas utilizadas pelos facilitadores?}

As partes chegam aqui com um termo de encaminhamento, geralmente acompanhadas de um estagiário do TJDFT. Em havendo disponibilidade e dependendo da natureza do conflito, iniciam-se os atendimentos desde logo. Caso contrário, num prazo geralmente de dois dias, são marcados os primeiros encontros, em horários diferentes para primeiramente os ofensores e depois as vítimas. $\mathrm{O}$ ofensor é consultado primeiro porque se verifica se ele pretende realmente continuar no processo e, assim, se está disposto a dialogar e assumir responsabilidade. Caso contrário, se fosse consultado primeiro a vítima e, depois, o ofensor não quisesse mais continuar, poderia ocorrer uma nova vitimização. 
Realizamos os procedimentos em três fases que chamamos de acolhimento, encontros privados e encontros restaurativos. No acolhimento, esclarecemos as vítimas sobre a justiça restaurativa, princípios e objetivos, é uma fase de informação preliminar. Neste primeiro contato, buscamos estabelecer o rapport criando um vínculo de confiança e de identidade com a parte, vítima ou agressor. Nos encontros privados, verificamos, separadamente, as questões, interesses e sentimentos das partes. Não há julgamentos, pois nós temos que ser neutros. Geralmente, as partes chegam aqui dizendo que "querem que o juiz decida". Daí, falamos sobre as desvantagens de processo penal normal e incentivamos que a parte enxergue o outro. Ofensor enxergue a vítima e a vítima enxergue o ofensor.

No encontro restaurativo é o momento de encontro entre a vítima e ofensor. Neste momento, expõem suas emoções e sentimentos. Todos os sentimentos são legítimos, sejam quais forem, devem ser respeitados. Há regras para um diálogo ser respeitoso e produtivo. Não admitimos ironias, nem sarcasmos, nem provocação e nem desqualificação, pois as partes devem ser igualmente tratadas de forma respeitosa. Orientamos sobre a forma de um diálogo livre, mas sem comunicação violenta.

A justiça restaurativa funciona como um guarda-chuva, debaixo dela nós aplicamos práticas de mediação e negociação. Essas técnicas empoderam as partes para elas mesmo resolverem as suas questões. A resolução do conflito deve partir delas. Nós ajudamos, de certa forma, a que as partes cheguem a um acordo, mas não determinamos o acordo em si. A vítima empoderada vai dizer como ela deve ser reparada. O ofensor também precisa se responsabilizar e querer reparar. Geralmente, em muitos casos, como nos conflitos de relações continuadas, as partes são vítimas e ofensores ao mesmo tempo. Segundo a teoria dos conflitos, estes começam pequenos e, se não resolvidos, tornam-se enormes e envolvem toda a família, podendo se perpetuar por vários anos.

\section{5)Há a preocupação com a celeridade dos procedimentos?}


Em média, aqui no centro, é realizado um encontro privado com cada parte. Mas, o critério que utilizamos é o empoderamento dos envolvidos. São as partes que ditam o ritmo e não nós, pois a preocupação é de oferecer um bom atendimento, uma verdadeira resolução do conflito. Assim, serão, na prática, realizados quantos encontros forem necessários. Inclusive, muitas vezes, fazemos atendimentos domiciliares, que levam mais tempo, para melhor atendê-los no seu contexto.

\section{6)Quais são, geralmente, os conteúdos dos acordos restaurativos?}

$\mathrm{Na}$ maior parte dos casos, as vítimas aceitam um pedido de desculpas como reparação. Pouquíssimos casos se concentram no conteúdo financeiro. O facilitador não pode jamais forçar a realização e nem o conteúdo de um acordo, pois ficaria prejudicada a autonomia das partes e a restauração. Nós ficamos atentos apenas para que não haja nenhuma lesão aos direitos das partes. Na maioria dos casos, as partes dizem que não querem vingança, mas sim "limpar a área", o que, na verdade, eles querem dizer que querem desobstruir o canal de comunicação.

\section{7)Quais são os tipos penais que predominantemente são encaminhados para cá?}

Para responder essa pergunta, foram repassados alguns documentos que contêm os dados estatísticos organizados pela equipe técnica. Tais dados foram analisados e constam nas tabelas apresentadas no capítulo 4 deste trabalho. Na entrevista, os facilitadores ressaltaram que são muito comuns os casos de ameaça, briga de vizinhos e lesão corporal.

\section{8)Qual a importância da comunidade no processo restaurativo? Como se dá a participação comunitária no programa?}

A comunidade gera empoderamento às partes. Aqui, nós chamamos de apoiadores. Os apoiadores servem de padrinhos, pois ajudam a sustentar o acordo. Caso contrário, também o acordo fica sem lastro. A comunidade como apoiadora contribui para a paz social e para a justiça. $\mathrm{O}$ critério para escolher os apoiadores não é apenas a proximidade, mas também o poder de negociação que eles têm no conflito, ou seja, o 
poder de interferir na relação. Funcionam como mesas de negociação. Como exemplo: teve um caso de lesão corporal ocorrido na porta de uma igreja e tanto a vítima como o ofensor freqüentavam a mesma igreja. Nós convidamos o padre da paróquia para funcionar como apoiador.

Houve outro caso em que a briga entre vizinhos era tão acentuada que convidamos outros vizinhos pra participar do processo. Foram envolvidas 16 pessoas neste processo. A briga começou por causa dos filhos que jogavam bola na rua. Os vizinhos, que eram dois casais, e que brigavam entre si disseram, no primeiro encontro restaurativo, que como que irão, a partir do acordo, se cumprimentarem na rua se todos os vizinhos sabiam que eles eram intrigados? Por isso, chamamos os vizinhos pra fortalecer o acordo.

O critério para escolher os apoiadores é também o de convivência próxima, as pessoas que podem passar a ter uma convivência duradoura. Mas também há casos em que as partes não tinham nenhuma relação.

\section{9) Há avaliação quanto aos resultados do projeto, como, por exemplo, quanto à reincidência dos ofensores?}

Não nos recordamos de nenhum caso em que foi realizado acordo e que tenha voltado para cá. Mas, quanto aos casos que as partes não fizeram acordo, teve pouquíssimos que voltaram. Estimamos, senso comum mesmo, que a proporção é de 1 ofensor reincidente dentro de 100 casos encaminhados. Pelo que lembramos os casos em que houve reincidência foram de ameaça e lesão corporal. Nesses, havia algum tipo de dependência química por parte dos agressores. Por enquanto, carecemos de pesquisas qualitativas quanto à reincidência. Em termos quantitativos, há gerenciamento no projeto. Porém, atualmente, desde março (2011), é que os relatórios e questionários de avaliação estão sendo entregues, havendo ou não acordo, para todas as partes. Antes não existia essa metodologia, era apenas esporadicamente. 
10) Há no programa serviços que permitam o acompanhamento das partes, principalmente quanto aos ofensores, no que tange aos motivos que existem por trás dos comportamentos delitivos (uso de entorpecentes, álcool, etc.)?

No programa especificamente de justiça restaurativa não há. Aqui, no TJDFT, há o Serviço Psicossocial Forense. Podemos sugerir ao juiz que mande as partes que precisarem para lá.

11) Posicionamento pessoal quanto à ampliação para os crimes de maior potencial ofensivo?

Facilitador 1: Concordo com a ampliação, porque não significa descriminalização das condutas e, nestes casos, também pode haver uma grande responsabilização moral. Os ofensores desses tipos de crimes também podem reconhecer que foi ultrapassado um limite. Acho que seria possível, se fosse dado mais importância às normas-princípios do Direito.

Facilitador 2: Acredito que pode ser possível e tão eficaz quanto aos crimes menores. No entanto, os procedimentos devem ser bem trabalhados. Já pude atuar em um caso de estupro contra uma menor e o resultado foi bastante positivo. 


\section{ANEXOS}

1. TERMO DE CONFIDENCIALIDADE DA PESQUISA

2. MODELO DE ACORDO RESTAURATIVO DO PROGRAMA DO NÚCLEO BANDEIRANTE

3. MODELO DA PESQUISA DE OPINIÃO INICIADA EM 2011 
Poder Judiciário da União

Tribunal de Justiça do Distrito Federal e dos Territórios

Centro Judiciário de Solução de Conflitos e de Cidadania do Programa Justiça Restaurativa

Avenida Contorno Lote 14, sala 12, Térreo - Fórum do Núcleo Bandeirante,

fone: 3103-2040, 3103-2042, e-mail: justicarestaurativa@tidft.jus.br. CEP:71705-535, Brasilia-DF

Expediente: segunda à sexta-feira, das $12 \mathrm{~h}$ às $19 \mathrm{~h}$

\section{TERMO DE CONFIDENCIALIDADE}

Eu, Amanda Almeida Waquim (RG: 138676120003 - SSP/MA // CPF: 025305673-01), aluna do $12^{\mathrm{a}}$ período do curso de Direito noturno - UNB, residente domiciliar na SQN 302 Bloco $\mathrm{F}$ Apartamento 403 - Asa Norte, Brasilia/DF; telefones: 3905-8093 // 8215-0640; e-mail: amandawaquim@hotmail.com fui comunicada quanto aos objetivos da pesquisa de forma clara e detalhada. Recebi informações a respeito e esclareci minhas dúvidas. Fui informada e esclarecida de que não poderei, senão para fins acadêmicos, reproduzir as informações aqui obtidas. Estou ciente de que minha participação na pesquisa será utilizada para fins de investigação na monografia de graduação em Direito, cujo tema é a Justiça Restaurativa, tendo como título "A necessidade de ampliação da Justiça Restaurativa no Brasil a partir de um olhar sobre o Projeto aplicado no Núcleo Bandeirante/DF". Esta pesquisa será realizada também em conjunto com a Universidade de Brasilia - UNB. Também estou ciente de que os dados da pesquisa não poderão ser publicados futuramente na forma de tese, livros, relatórios, artigos, anais de eventos científicos e comunicações, senão com a devida autorização. Não existem vantagens diretas para mim ao responder as questões em entrevistas, ao permitir a gravação de minhas intervenções em encontros e ciclos restaurativos, em reuniões de estudo e de trabalho e também em situações de atendimento. Os resultados desse estudo são de elevada relevância para a compreensão e análise da Justiça Restaurativa.

Declaro que recebi cópia do presente termo.

25/05/2011.

Amando HAtmida Waquim
AMANDA ALMEIDA WAQUIM
Pesquisadora Responsável




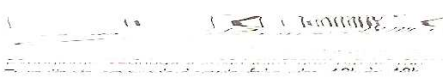

Justiça Restaurativa - Pesculuisa de Opinião

Questionário $\mathrm{N}^{\circ}$

Data:

Horário: / 2011

\begin{tabular}{|l|l|l|}
\hline No Processo & & $\square$ Vítima \\
\cline { 1 - 3 } Facilitadores: & Parte & $\square$ Advor \\
$\square$ Advogado do Autor \\
$\square$
\end{tabular}

1 - O encontro iniciou no horário?

$\square \operatorname{Sim}$

Não, atrasou minutos

2 - O (a) $\mathrm{Sr}$ (a) acredita que o tempo de duração do encontro foi:

$\square$ Muito rápido $\square$ Rápido $\quad \square$ Razoável $\square$ Curto $\square$ Muito Curto

3 - Qual foi o resultado de scu cncontro?

$\square$ Acordo $\square$ Sem acordo $\square$ Desistência $\square$ Outros:

4-O (a) Sr (a) acredita que o resultado do encontro foi:

$\square$ Muito Justo $\square$ Justo $\square$ Razoável $\square$ Injusto $\quad \square$ Muito Injusto

Obs:

5 - O (a) Sr (a) acredita que a Justiça Restaurativa ajudou a resolver o conflito?

$\square \operatorname{Sim}$

$$
\square \text { Não }
$$

6-A Justiça Restaurativa soube esclarecer suas dúvidas?

$\square \operatorname{Sim}$

$\square$ Não

7 - O (a) Sr (a) acredita que a Justiça Restaurativa está preparada / capacitada para ajudar as partes a resolver "jeus con'litos?

$\square \mathrm{Sim}$

$\square$ Não 
8- Vo seu caso, especificamente, o (a) Sr (a) entende que os encontros seriam melhores conduzidos:

$\square$ Pela Justiça Restaurativa $\quad \square$ Diretamente com o (a) Juiz (íza)

9 - O (a) Sr (a) seritiu que a Justiça Rıstaurativa defendeu uma das partes e prejudicou a outra?

$\square \operatorname{Sim}$

$\square$ Não

10 - O (a) Sr (a) sentiu-se pressionado (a) a chegar a um acordo ou a fechar um acordo?
$\square \operatorname{Sim}$
$\square$ Não
$\square$ Sim, em parte
$\square$ Não sei responder

11 - De maneira geral, como o Sr (a) avalia os encontros realizados pela Justiça Restaurativa?
$\square$ Excelentes
$\square$ Bons
Razoáveis
$\square$ Ruins
Péssimos

12 - Satisfação com o procedimento:

Regular

$\square$ Ruim

$\square$ Péssimo

13 - Quanto aos facilitadores:

Cortesia: $\square$ Excelente $\square$ Bom $\square$ Regular $\square$ Ruim $\square$ Péssimo

Imparcialidade: $\square$ Excelente $\square$ Bom $\square$ Regular $\square$ Ruim $\square$ Péssimo

Forma de conduzir os encontros: $\square$ Excelente $\square$ Bom $\square$ Regular $\square$ Ruim $\square$ Péssimo

14 - Tempo de espera para agendar os encontros:

$\square$ Excelente $\square$ Bom $\square$ Regular $\square$ Ruim $\square$ Péssimo

15 - Já tinha conhecimento da Justiça Restaurativa?

$\square$ Sim, por meio de:

$\square$ Não

O que o (a) senhor (a) entende que poderia ser melhorado?

Resposta:

Caso o (a) senhor (a) queira receber resposta ou contato deste Serviço sobre suas solicitações / sugestões ou reclamações, favor informar seu nome, telefone e / ou e-mail:

Nome:

Telefone: Res: $($ )

E-mail:

Cel: ( 
Poder Judiciário da União

Tribunal de Justiça do Distrito Federal e dos Territórios

Centro Judiciário de Solução de Conflitos e de Cidadania do Programa Justiça Restaurativa

Avenida Contorno Lote 14, sala 12, Térreo - Fórum do Núcleo Bandeirante,

fone: 3103-2040 // 3103-2042, e-mail: justicarestaurativa@tjdft.jus.br, CEP:71.705-535, Brasilia-DF

Expediente: segunda à sexta-feira, das $12 \mathrm{~h}$ às $19 \mathrm{~h}$

TERMO DE ACORDO RESTAURATIVO

Aos $X X X X$ dias do mês de $X X X X$ do ano de dois mil e onze, às $X X X X$ horas na sala $n^{\circ} 12$ (doze) da Justiça Restaurativa deste Juízo, localizada no Fórum do Núcleo Bandeirante-DF, perante os facilitadores $X X X X$, compareceram as partes: $X X X X$ e $X X X X$ para a realização do presente Encontro Restaurativo referente ao processo de $n^{\circ} X X X X$ do $X X X X$ Juizado $X X X X$, que cuida de incidência do Artigo $X X X X$.Preparatórios ao presente encontro restaurativo ocorreram $X X X X$ encontros, sendo $X X X X$ privados e $X X X X$ conjuntos, $X X X X$ telefonemas, e $X X X X$ telegrama. Após serem esclarecidas acerca do que se propõe a Justiça Restaurativa, as partes tiveram oportunidade de se expressarem sobre o(s) fato(s) que desencadearam o conflito, que originou $o$ processo judicial, bem como de expressarem seus sentimentos e interesses a respeito, resultando do encontro o Acordo Restaurativo, nos seguintes termos: as partes se desculparam, reciprocamente; reconhecem a necessidade do convívio respeitoso e saudável entre todos os envolvidos (vítima, ofensor, seus familiares e membros da comunidade) nos processos judicial e restaurativo. As partes concordam ainda que sobre o ocorrido não mais deverão discutir entre si, nem entre seus familiares e/ou vizinhos, evitando desta forma, atitudes de provocação e incitação ao conflito. Para o futuro, reconhecem que, se houver necessidade, deverão buscar apoio de profissionais especializados e/ou pessoas neutras, capazes de auxiliá-los na busca de resolução dos conflitos, oriundos na família ou na comunidade, de forma adequada. Sendo assim, as partes se comprometem a colaborarem para a promoção da paz social em sua comunidade, evitando comportamentos que possam ameaçar, desqualificar, constranger, perturbar o sossego, a tranqüilidade, a integridade física e moral uma da outra, e bem assim, dos familiares de cada qual, ficando cientificados de que, em caso de descumprimento do acordo e cometimento de qualquer delito, responderão criminalmente pelo que fizerem. Que em face do presente acordo as partes renunciam expressamente ao direito de representação em relação aos fatos noticiados no Termo Circunstanciado referente a este processo. Requerem às partes que este Termo de Acordo Restaurativo seja encaminhado ao Juiz, para homologação. Que não tendo mais nada a declarar, todos assinam o presente Termo de Acordo Restaurativo.

Partes:

$\mathrm{XXXX}$

$x \times X X$

Familiares apoiadores:

$\mathrm{x} \times \mathrm{XX}$

$X X X X$

Facilitadores:

$\mathrm{XXXX}$

$\mathrm{X} \times X \times$ 